\title{
FUnCTIONAL MATERIALS - SYNTHESES, Characterisation and Catalytic ApPlications
}

PhD Dissertation

\section{MóNIKA SIPICZKI}

\author{
Supervisors: \\ DR. PÁl SIPOS \\ DR. ISTVÁN PÁLINKÓ
}

\begin{abstract}
Doctoral School of Chemistry
Material and Solution Structure Research Group

Department of Inorganic and Analytical Chemistry

Department of Organic Chemistry

Faculty of Science and Informatics | University of Szeged
\end{abstract}

Szeged

2013 


\section{TABLE OF CONTENTS}

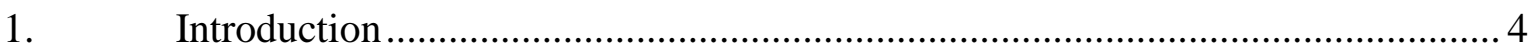

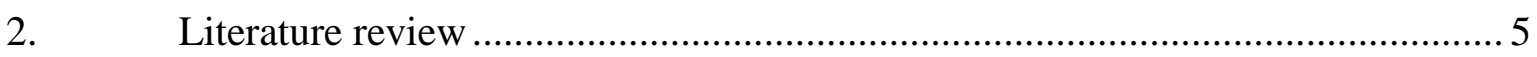

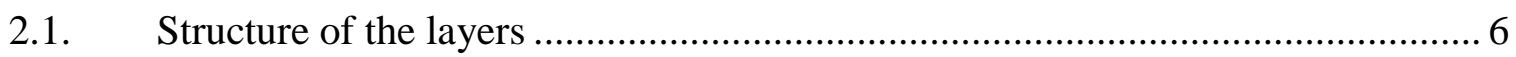

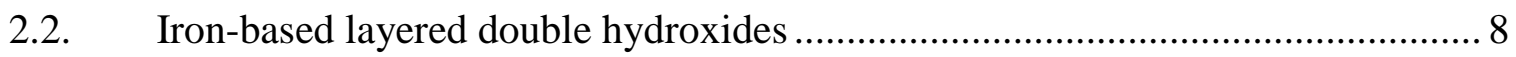

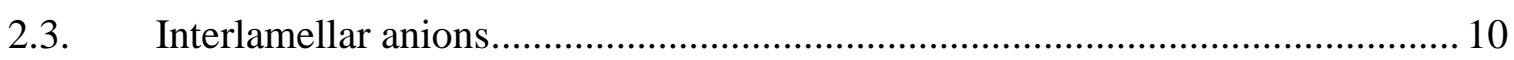

2.4. Preparative chemistry of anion-intercalated layered double hydroxides ............ 11

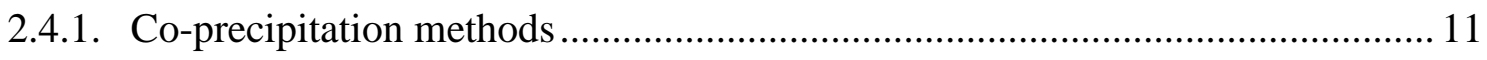

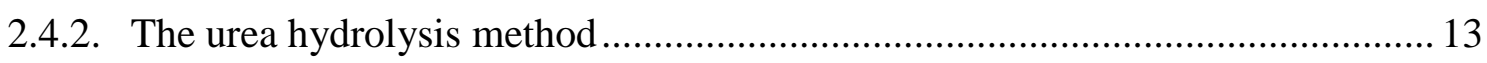

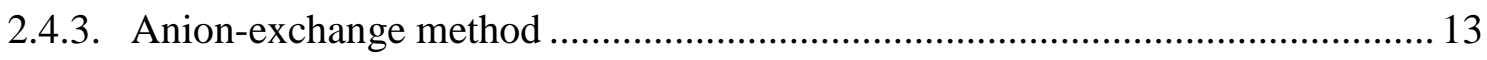

2.4.4. Dehydration-rehydration (reconstruction) method ........................................... 14

2.5. Applications of layered double hydroxides .................................................. 16

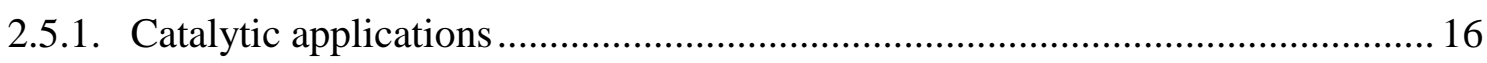

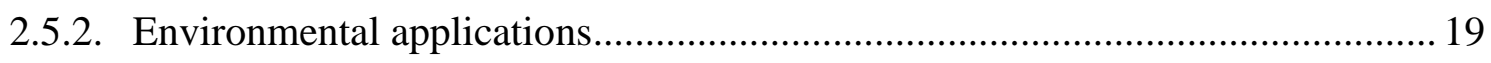

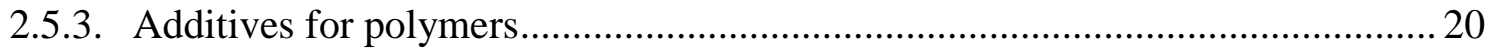

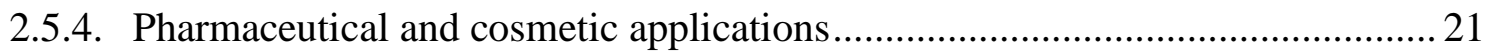

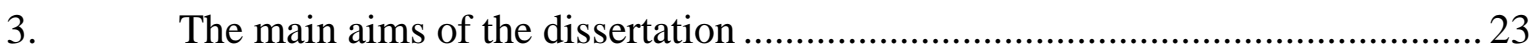

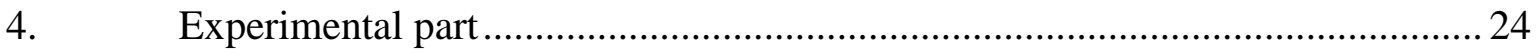

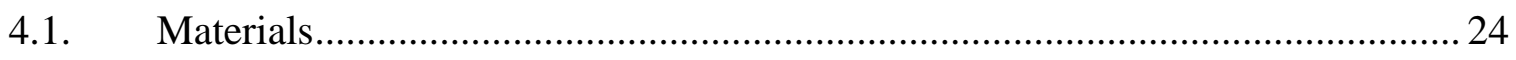

4.2. Preparation of concentrated and carbonate-free $\mathrm{NaOH}$ solution .......................2 25

4.3. Synthesis of the layered double hydroxides.................................................. 25

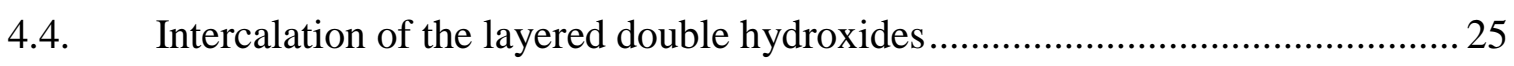

4.5. Immobilisation of L-proline in functionalised chloropropylated silica gel ........26

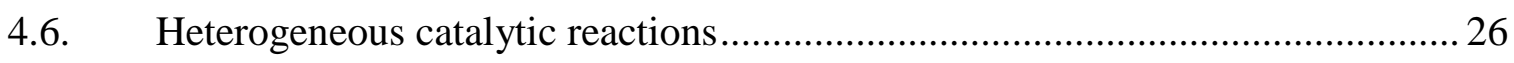

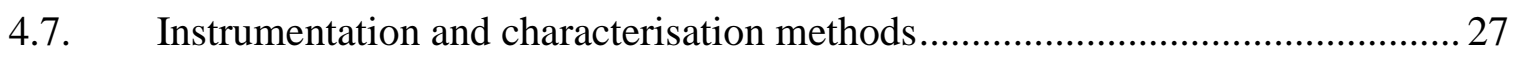

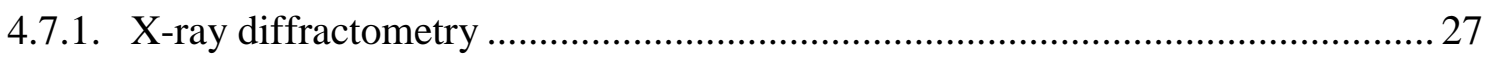

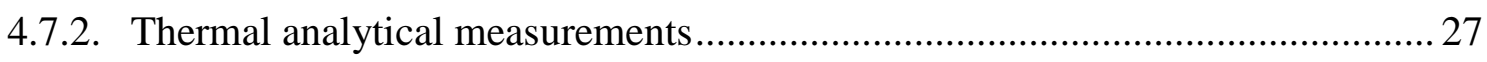

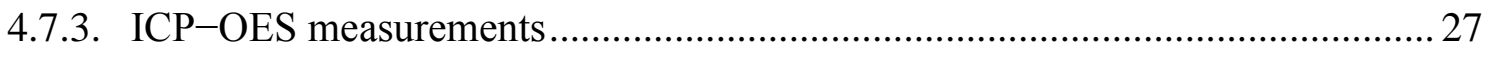

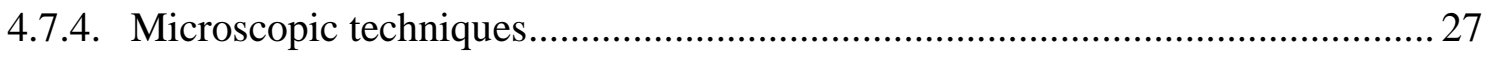

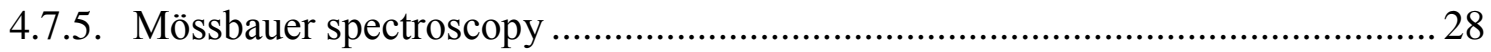




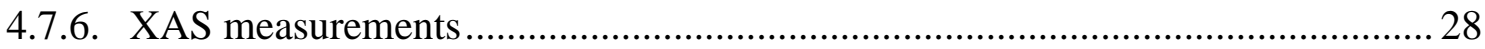

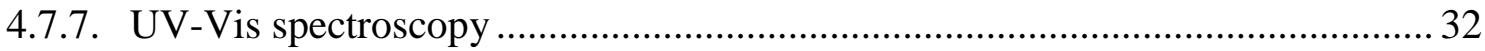

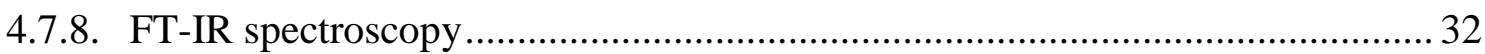

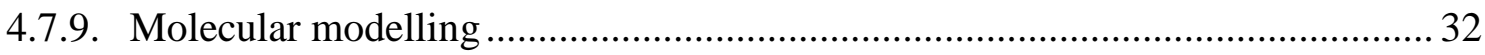

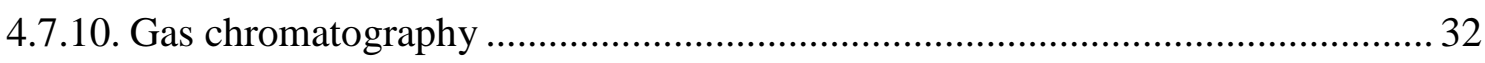

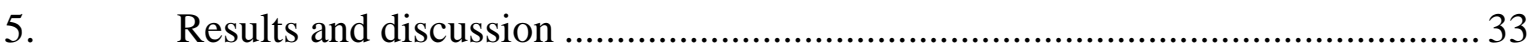

5.1. Preparation and characterisation of $\mathrm{Ca}(\mathrm{II}) \mathrm{Fe}(\mathrm{III})-$ and $\mathrm{Mg}(\mathrm{II}) \mathrm{Fe}(\mathrm{III})$ layered

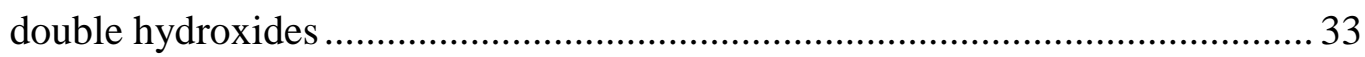

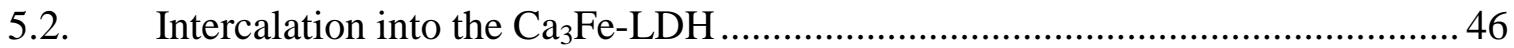

5.3. The application of pristine $\mathrm{CaFe}-\mathrm{LDH}$ as a catalyst in an epoxidation reaction 60

5.4. Preparation of immobilised organocatalysts and their application in cross-aldol

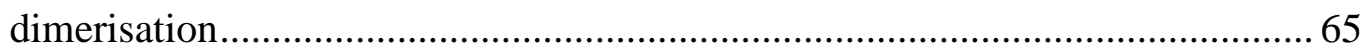

5.4.1. Composite materials as catalysts for aldol dimerisation reactions .................... 67

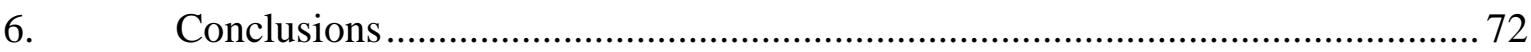

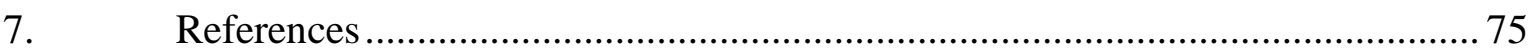




\section{INTRODUCTION}

Synthetic inorganic materials with well-defined structures and tailor-made functionalities exhibit useful properties for the solution of today's environmental and industrial problems and for the design of novel composites used in advanced technological processes. Among the several classes of lamellar solids, layered double hydroxides are of particular interest since they qualitatively resemble the conventional intercalation compounds with nanoscale periodicity and complete charge separation between the gallery ions and the layers. Significant progress has been made in the synthesis of layered double hydroxides with new compositions and morphologies over the last decade allowing improved applications in many areas. In this work, the catalytic properties of the uncalcined and intercalated varieties are demonstrated. Other functionalised solids like those displayed in this work can also have many applications. Once again their catalytic properties are highlighted in the dissertation. 


\section{LITERATURE REVIEW}

Layered double hydroxides (LDHs) are a group of anion-intercalated inorganic functional materials which are also known as anionic clays. These materials are not so prevalent in nature as the well-known cationic clays, but are very easy to prepare and they are inexpensive. The first natural mineral belonging to this family of materials was discovered in Sweden in 1842 , and is known as hydrotalcite. ${ }^{1}$ It has the formula of $\mathrm{Mg}_{6} \mathrm{Al}_{2}(\mathrm{OH})_{16} \mathrm{CO}_{3} \cdot 4 \mathrm{H}_{2} \mathrm{O}$. Since hydrotalcite is one of the most representative minerals of the group, the LDHs are also called 'hydrotalcite-like compounds' (HTlc), even though other natural as well as artificial structural varieties also exist. The structure of hydrotalcite is related to that of brucite, $\operatorname{Mg}(\mathrm{OH})_{2}$ which consists of $\mathrm{Mg}^{2+}$ ions octahedrally surrounded by hydroxide ions. These octahedral units form infinite layers by sharing edges, with the $\mathrm{O}-\mathrm{H}$ bond perpendicular to the plane of the layers. ${ }^{2}$ In the lattice of LDHs, trivalent $\mathrm{M}(\mathrm{III})$ cations (i.e., $\mathrm{Al}^{3+}$ in hydrotalcite) substitute some of the $\mathrm{Mg}^{2+}$ cations in the brucite layers resulting in positively charged host layers, while in the interlamellar area $\mathrm{A}^{\mathrm{n}-}$ anions are located in hydrated interlayer galleries to maintain electroneutrality. The host layers are stacked on top of one another to form a threedimensional structure. The general formula for other members of the family, based on a combination of divalent and trivalent metal cations, can be written as $\left[\mathrm{M}(\mathrm{III})_{1-\mathrm{x}} \mathrm{M}(\mathrm{III})_{\mathrm{x}}(\mathrm{OH})_{2}\right]^{\mathrm{x}+}\left[\mathrm{X}^{\mathrm{m}-}{ }_{\mathrm{x} / \mathrm{m}} \times \mathrm{nH}_{2} \mathrm{O}\right]^{\mathrm{x}-}$, where $\left[\mathrm{M}(\mathrm{II})_{1-\mathrm{x}} \mathrm{M}(\mathrm{III})_{\mathrm{x}}(\mathrm{OH})_{2}\right]^{\mathrm{x}+}$ represents the layer, and $\left[\mathrm{X}^{\mathrm{m}-}{ }_{\mathrm{x} / \mathrm{m}} \times \mathrm{nH}_{2} \mathrm{O}\right]^{\mathrm{x}-}$ the interlayer compositions (Figure 1). The divalent and trivalent metal cations found in layered double hydroxides belong mainly to the third and fourth periods of the table of elements (divalent cations: $\mathrm{Mg}, \mathrm{Mn}, \mathrm{Fe}, \mathrm{Co}, \mathrm{Ni}, \mathrm{Cu}, \mathrm{Zn}$; trivalent cations: Al, Mo, $\mathrm{Fe}, \mathrm{Co}, \mathrm{Cr}, \mathrm{Ga}) \mathrm{The}$ ionic radii are mostly in the range $0.65-0.80 \AA$ for divalent cations and 0.62-0.69 $\AA$ for trivalent ones (there are some exceptions like Al: $0.50 \AA$ and Ba: $1.49 \AA$ ). ${ }^{3}$ Tetravalent cations such as $\mathrm{Zr}^{4+}$ and $\mathrm{Sn}^{4+}$ can also be incorporated into the layers. ${ }^{4}$ Only one example is known of LDH structure with monovalent cation, the $\mathrm{LiAl}_{2}-\mathrm{LDH}$ that is. It has been speculated that the ionic radii of $\mathrm{M}(\mathrm{II})$ and $\mathrm{M}(\mathrm{III})$ and the difference between them, ${ }^{5,6}$ as well as the solubility products $^{7}$ of $\mathrm{M}(\mathrm{II})(\mathrm{OH})_{2}$ and $\mathrm{M}(\mathrm{II}) \mathrm{CO}_{3}$, play roles in defining the boundaries of the range of metal cations that can form LDHs.

Many researchers have suggested ${ }^{5,8}$ that pure LDH phases can only be formed for stoichiometries in the

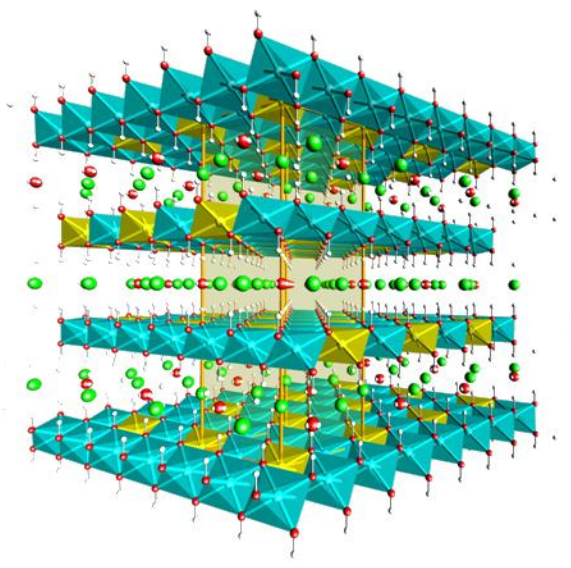

Figure 1. The schematic structure of a layered double hydroxide ( $L D H)$. 
range $0.20<\mathrm{x}<0.33$, corresponding to $\mathrm{M}(\mathrm{II}) / \mathrm{M}$ (III) molar ratios in the range $2-4$. For $\mathrm{x}>0.33$, the presence of $\mathrm{M}(\mathrm{III})-\mathrm{OH}-\mathrm{M}$ (III) linkages is unavoidable and this is energetically unfavourable due to the strong repulsion between the adjacent trivalent cations. ${ }^{9,10}$

\subsection{Structure of the layers}

In layered double hydroxides, the octahedral environment of metallic cations is far from being a regular polyhedron. The octahedra are significantly flattened along the stacking direction, lowering the symmetry from $\mathrm{O}_{\mathrm{h}}$ to $\mathrm{D}_{3 \mathrm{~d}}$, as illustrated in Figure 2 for a ZnAl- LDH. The higher is the metal ionic radius, the more flattened are the octahedra with lowering of the layer thickness $h$ and an increase of the distance $a$ between metals - which is the same as the one between the $\mathrm{OH}$ groups on the same side of the layer. ${ }^{11}$ All brucite-like metal hydroxides show this type of distortion, ${ }^{12,13}$ which results in hexagonal symmetry (space group P-3m1). The weak forces between the layers of brucite have been attributed to contributions from dispersion forces and hydrogen bonding. ${ }^{2,14}$

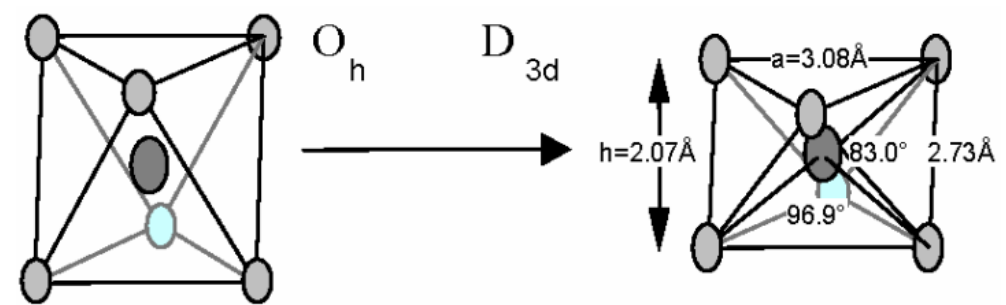

Figure 2. Flattening of the $\mathrm{M}(\mathrm{OH})_{6}$ octahedron in a $\mathrm{ZnAl}-\mathrm{LDH}$.

Layered materials are characterised by strong polar covalent bonding along two dimensions and weak bonding along the third dimension, which is also the stacking direction. Given the weak bonding between layers, the layers can stack, in a multiplicity of patterns, called stacking sequences, to yield different polytypes. Polytypism is best defined as polymorphism in one dimension. All polytypes can be classified in the frame of the number of stacked sheets along the $c$ axis in the unit cell. The brucite-like layers in LDHs may be stacked in various ways, giving rise to a variety of possible polytype structures. If the opposing $\mathrm{OH}$ groups lie vertically above one another; an interlayer with a trigonal prismatic arrangement is resulted, whilst an octahedral arrangement is formed if they are offset. ${ }^{15}$ There are three possible two-layer polytypes with hexagonal stacking of the layers, denoted as $2 \mathrm{H}_{1}$ , $2 \mathrm{H}_{2}$, and $2 \mathrm{H}_{3}$ where the $2 \mathrm{H}_{1}$ polytype has all prismatic interlayers and the $2 \mathrm{H}_{2}$ polytype has all octahedral interlayers while both types of interlayers are present in the $2 \mathrm{H}_{3}$ polytype. There are nine possible three-layer polytypes of which two have rhombohedral symmetry- $-3 R_{1}$ and 
$3 \mathrm{R}_{2}$ - while the remaining seven $\left(3 \mathrm{H}_{1}-3 \mathrm{H}_{7}\right)$ have hexagonal symmetry. The $3 \mathrm{R}_{1}$ polytype has all prismatic interlayers; $3 \mathrm{R}_{2}, 3 \mathrm{H}_{1}$, and $3 \mathrm{H}_{2}$ have all octahedral interlayers and other polytypes involve both types. The various possible six-layer polytypes with rhombohedral $(6 \mathrm{R})$ and hexagonal symmetry $(6 \mathrm{H})$ have also been described. ${ }^{15,16}$ Hydrotalcite $\left[\mathrm{MgAl}\left(\mathrm{CO}_{3}\right)\right.$ $\mathrm{LDH}$ ] has the $3 \mathrm{R}_{1}$ polytype structure, which most other carbonate-containing LDHs also adopt, ${ }^{11}$ since the prismatic arrangement of hydroxyl groups facilitates hydrogen bonding with the oxygen atoms of the $\mathrm{CO}_{3}{ }^{2-}$ anion and the interlayer water molecules. It is difficult to distinguish between the various polytypes, since the intensities of reflections in the XRD pattern of an LDH are sensitive to the interlayer anion.

If the radius of one of the metallic cations becomes too high, the octahedral coordination is lost by opening one side of the octahedron on the interlamellar domain leading to additional coordination with one interlamellar water molecule. The symmetry around the metal is lowered from $D_{3 d}$ to $C_{3 v}$. Such behaviour is observed in minerals from the hydrocalumite group. For CaAl-based layers, three different short range distances are observed ${ }^{11}$ around calcium: $3 \mathrm{Ca}-\mathrm{OH}$ at $2.375 \AA, 3 \mathrm{Ca}-\mathrm{OH}$ at $2.455 \AA$, and $1 \mathrm{Ca}-\mathrm{OH}_{2}$ at $2.497 \AA$. The structure is based on corrugated brucite-like main layers with an ordered arrangement of $\mathrm{Ca}$ (II) and $\mathrm{M}(\mathrm{III})$ ions, seven- and six-coordinated, respectively, the seventh apex of the Ca-polyhedron is a water molecule from the interlayer. The composition of the hydroxide layer of this structure type is limited; the divalent and trivalent cations are typically $\mathrm{Ca}^{2+}$ and $\mathrm{Al}^{3+}$. These lamellar calcium aluminium hydroxides salts have been studied in detail, for they occur in the hydration process of cement compounds. ${ }^{17}$ The replacement of $\mathrm{Al}^{3+}$ by $\mathrm{Fe}^{3+}, \mathrm{Cr}^{3+}, \mathrm{Ga}^{3+}$, and $\mathrm{Ca}^{2+}$ by $\mathrm{Cd}^{2+}$ have been reported but only few data are available on these phases. ${ }^{18}$ Several rhombohedral space groups, a monoclinic one and the two triclinic space groups have been observed for synthetic monoanionic tetracalcium aluminates. In the rhombohedral space groups R-3 and R-3c, the water molecules linked to $\mathrm{Ca}$ atoms are on the straight line passing through the $\mathrm{Ca}$ atoms and perpendicular to the (001) plane (Figure 3).

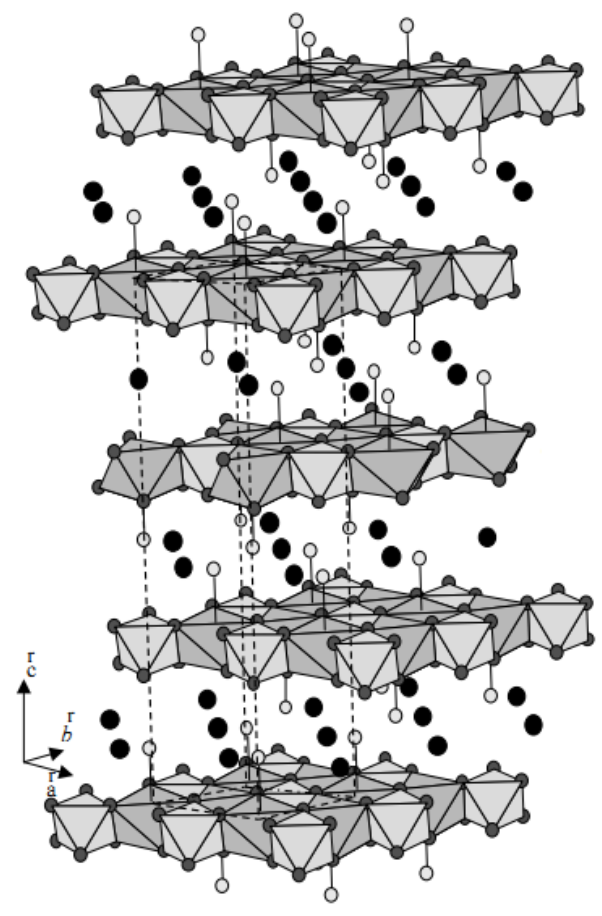

Figure 3. Crystal structure of $\mathrm{Ca}_{2} \mathrm{Al}(\mathrm{OH})_{6} \mathrm{Cl} \cdot 2 \mathrm{H}_{2} \mathrm{O}$, in $\mathrm{R}-3$ space group. 
The neighbouring brucite-like layers may be stacked in two different ways building two kinds of interlayers: either $\mathrm{OH}$ groups form prisms resulting in a three-layer polytype $(3 \mathrm{R})$ and the R-3 unit cell or they form octahedra resulting in a six-layer polytype (6R) and the R$3 \mathrm{c}$ unit cell. As already noticed, ${ }^{19}$ the change of space group from R-3 to R-3c depends on the size of the anions. Indeed, chloride compound crystallizes in the space group R-3c, larger anions like iodine and sulphate compounds crystallize in R-3 while intermediate anions like bromide exhibit both unit cells.

The replacement of $\mathrm{Al}^{3+}$ cations by larger $\mathrm{M}^{3+}$ cations in hydrocalumites results in a linear variation of the unit-cell parameters: $a$ increases and $c$ decreases as the $\mathrm{M}^{3+}-\mathrm{OH}$ bond length increases. In the octahedral layer, the accommodation of longer $\mathrm{M}^{3+}-\mathrm{OH}$ distances proceeds like in hydrotalcite-like compounds, i.e., by flattening the $\mathrm{M}^{3+}(\mathrm{OH})_{6}$ octahedra along the $c$-axis in order to minimise the repulsion between cations. ${ }^{20}$ This distortion evidenced by the HO-M(III)-OH bond angle values given by Rousselot et al. ${ }^{21}$ The overall effect on these octahedral layers is thus a compression in the $c$ direction and an elongation in the $(a, b)$ plane.

\subsection{Iron-based layered double hydroxides}

For natural LDHs the chemical composition is the main fundamental characteristic feature to distinguish individual minerals and to name them. At present, the following major cation compositions have been recognized among natural layered double hydroxide minerals: MgAl (hydrotalcite-manasseite), MgFe (pyroaurite-sjögrenite), NiFe (honessite-reevesite), $\mathrm{NiAl}$ (takovite), $\mathrm{CuAl}$ (woodwardite), $\mathrm{MgCr}$ (stichtite), etc. A particular type of LDHs which contains only iron as a cation in the brucite-type layers is called green rust, $\mathrm{Fe}(\mathrm{II}) \mathrm{Fe}(\mathrm{III})-\mathrm{LDH}$ that is. If we focus on the layered double hydroxides synthesised in laboratory, we found that a diverse combination of $\mathrm{M}^{2+}-\mathrm{M}^{3+}$ cations in the $\mathrm{LDH}$ host sheets has been extensively pursued, and can be routinely attained through a convenient co-precipitation of corresponding di- and trivalent metal salts under alkaline conditions. This in fact yields a large family of LDHs. Nevertheless, the research interest on LDH materials has been traditionally driven and predominated by $\mathrm{M}(\mathrm{II})-\mathrm{Al}(\mathrm{III})$ category, particularly $\mathrm{Mg}^{2+}-\mathrm{Al}^{3+}$, partly due to the fact that hydrotalcite is a widely known anionic clay found in nature. In addition, the amphoteric feature of $\mathrm{Al}^{3+}$ also plays a very favourable role in promoting the precipitation and crystallisation of Al-based LDHs. By virtue of this amphoteric feature, well-crystallized $\mathrm{M}(\mathrm{II}) \mathrm{Al}(\mathrm{III})-\mathrm{LDH}$ crystallites have been readily synthesised. 
Without the incorporation of amphoteric $\mathrm{Al}^{3+}$ into the host sheet, it is more difficult to synthesise LDH in a highly crystalline form. Consequently, non-Al(III) LDHs remain as the least explored category. Relatively few articles describe the structures of the layers in ironcontaining layered double hydroxides..$^{22,23,24,25}$ It is surprising, since Fe(III)-based layered double hydroxides can be prosperous, especially if used in catalysis. In aqueous media the iron(III) ion is water-soluble in a much narrower $\mathrm{pH}$ range than aluminium(III) ions. $\mathrm{Al}^{3+}$ ion is considered toxic (e.g., thought to be related to the development of Alzheimer-disease), thus its biological applications are highly restricted. The variable valence of iron is well-known and, therefore, the iron-containing layered double hydroxides may be important in catalysis. Another advantage of iron-containing layered double hydroxides, that they can be converted into magnetisable materials, which can lead some non-conventional applications. It has to be noted, however, that in industrial applications the amphoteric properties of aluminium may also play a role, since in highly alkaline medium the $\mathrm{Al}(\mathrm{III})$-containing layered double hydroxides are not stable.

It is worth mentioning that many of the experimental methods (for example Mössbauer spectroscopy, ESR, UV-Vis) can be employed for studying double hydroxides containing iron, but not that of aluminium. Among them let me detail ${ }^{57} \mathrm{Fe}$ Mössbauer spectroscopy. Relatively few articles describe the structures of the layers in iron-containing LDHs with the assistance of Mössbauer spectroscopy. ${ }^{57} \mathrm{Fe}$ Mössbauer spectroscopy has been used to investigate the mechanisms of oxidation of $\mathrm{Ni}(\mathrm{II}) \mathrm{Fe}(\mathrm{II})$ hydroxides and its role in the synthesis of pyroaurite-type $\mathrm{NiFe}-\mathrm{LDH},{ }^{26}$ the oxidation state of iron in complexes such as $\left[\mathrm{Fe}(\mathrm{CN})_{6}\right]^{3-14-}$ intercalated in layered double hydroxides ${ }^{27}$ and ferrocene sulphonates intercalated in LDHs. ${ }^{28}$ Numerous studies focussing on the examination of the layers, deal with green rust-type $\mathrm{Fe}(\mathrm{II}) \mathrm{Fe}(\mathrm{III})-\mathrm{LDH}$. One explanation may be that the structural features of this LDH can be established completely from the ${ }^{57} \mathrm{Fe}$ Mössbauer spectrum presenting two ferrous quadrupole doublets $\mathrm{D}_{1}$ and $\mathrm{D}_{2}$ and one ferric doublet $\mathrm{D}_{3}$ in the paramagnetic state. ${ }^{29}$ In addition, the ferromagnetic behaviour of green rust ${ }^{30}$ and the effect of intercalation of linear C9-C16 carboxylates into layered Fe(II)Fe(III)-hydroxides have also been reported. ${ }^{31}$ It is clear from these few examples that ${ }^{57} \mathrm{Fe}$ Mössbauer spectroscopy has been used to study the structure of layers at a scarce, but it is not entirely unprecedented. ${ }^{23,24,25,32}$ 


\subsection{Interlamellar anions}

In LDHs the interlamellar domains contain anions, water molecules and sometimes other neutral or charged entities. One major characteristic of LDHs is that in most cases only weak bondings occur between these interlamellar ions or molecules and the host structure. A great variety of anionic species can therefore be introduced between the layers during the formation of the lamellar structure or by further anionic exchange. The following families of anions can be found within the layers:

- halides $\left(\mathrm{F}^{-}, \mathrm{Cl}^{-}, \mathrm{Br}^{-}, \mathrm{I}^{-}\right)$,

- non-metal oxoanions $\left(\mathrm{BO}_{3}{ }^{3-}, \mathrm{CO}_{3}{ }^{2-}, \mathrm{NO}_{3}{ }^{-}, \mathrm{Si}_{2} \mathrm{O}_{5}{ }^{2-}, \mathrm{HPO}_{4}{ }^{2-}, \mathrm{SO}_{4}{ }^{2-}, \mathrm{ClO}_{4}{ }^{-}, \mathrm{AsO}_{4}{ }^{3-}\right.$, $\mathrm{SeO}_{4}{ }^{2-}, \mathrm{BrO}_{4}{ }^{-}$etc.),

- oxo- and polyoxometallate anions $\left(\mathrm{VO}_{4}{ }^{3-}, \mathrm{CrO}_{4}{ }^{2-}, \mathrm{MnO}_{4}{ }^{-}, \mathrm{V}_{10} \mathrm{O}_{28}{ }^{6-}, \mathrm{Cr}_{2} \mathrm{O}_{7}{ }^{2-}, \mathrm{Mo}_{7} \mathrm{O}_{24}{ }^{6-}\right.$ etc.),

- anionic complexes of transition metals $\left(\mathrm{Fe}(\mathrm{CN})_{6}{ }^{2-}\right.$ etc. $)$,

- organic anions $\left(\mathrm{CH}_{3} \mathrm{COO}^{-}, \mathrm{C}_{6} \mathrm{H}_{5} \mathrm{COO}^{-}, \mathrm{C}_{12} \mathrm{H}_{25} \mathrm{COO}^{-}, \mathrm{C}_{2} \mathrm{O}_{4}{ }^{2-}, \mathrm{C}_{6} \mathrm{H}_{5} \mathrm{SO}_{3}{ }^{-}\right.$etc. $)$,

- anionic polymers (PSS, PVS, polyacrylate, etc.).

The structure of interlamellar domains is more difficult to characterise than the main layers. With small anionic species, such as halides and carbonates, and up to sulphatecontaining LDHs with a basal spacing of $1.1 \mathrm{~nm}$, a regular stacking of the layers is observed in the X-ray diffractograms. With bulky anions, in most cases the stacking of the layers does not display long-range ordering any more (turbostratic effect) and the diffractograms show only lines related to the basal spacing and the structure of the main layers.

Most of the articles on the intercalation chemistry of LDH describe the fully exchanged products, while only a few report on mixed ion-exchanged forms. In one, the competitive intercalation of $\mathrm{ClO}_{4}{ }^{-}$and $\mathrm{NO}_{3}{ }^{-}$into $\mathrm{ZnCr}-\mathrm{LDH}$ has been investigated. ${ }^{33}$ The two phases coexist, implying that the formation of phases with mixed anions in the interlayer space is energetically unfavourable. Theoretical models would suggest that regular stacking, referred to as 'staging', as commonly observed in graphite, does not occur in LDH due to the rigidity of the layers. ${ }^{34}$ However, using in situ time-resolved XRD, it was demonstrated ${ }^{35}$ that LiAl-LDH can form second-stage intermediates, i.e., every second layer is filled by dicarboxylate anions. Layer interstratification has been observed during the interlayer exchange of terephthalate with chloride and nitrate anions. ${ }^{36}$ This is ascribed to two orientations of terephthalate anions, vertical and horizontal they are, which can be controlled by varying the layer charge density and the extent of drying. Thus, it is possible that staging in LDH can occur either during the 
exchange process, or by direct synthesis, and is associated with different interlayer contents or different orientations of the same molecule.

The anions orient themselves in such a way that they maximise their interaction with the positively charged hydroxide layer. This feature is reflected in the interlayer spacing and is normally valid for $3 \mathrm{R}$ stacking, also denoted by the $\mathrm{d}(003)$ value. In pristine $\mathrm{LDH}, \mathrm{CO}_{3}{ }^{2-}$ anions lie parallel to the hydroxide layer to ensure intimate interaction between the oxygen atoms and the layer by forming hydrogen bonds. ${ }^{37}$ Organic anions always interact via their anionic groups being strongly hydrogen bonded to the surface hydroxyl groups, while their hydrophobic hydrocarbon chains are pushed far away from the hydrophilic layer surface, and adopt the lowest energy conformation. ${ }^{38}$

\subsection{Preparative chemistry of anion-intercalated layered double hydroxides}

Layered double hydroxides are simple and inexpensive to synthesise both on laboratory and industrial scales. Many methods allow the preparation of materials with tailored physical and chemical properties suitable for many applications.

\subsubsection{Co-precipitation methods}

This is the most common preparative method of LDHs. It is based on the slow addition of a mixed solution of divalent and trivalent metal salts in appropriate ratio. A second (alkaline) solution is added to the reactor in order to maintain the $\mathrm{pH}$ at a selected value leading to the co-precipitation of the two metallic salts. The mechanism of co-precipitation is ideally based on the condensation of hexa-aqua complexes in solution, leading to the build-up of the brucite-like layers with close to evenly distributed metallic cations and with solvated interlamellar anions. Observation of the precipitates and X-ray diffraction characterisation show that the co-formation of the main layers and interlamellar domains takes place at a very early stage of the process without clear "delaminated" state of the layers. ${ }^{11}$

The metal cations in the layers of the obtained material are originated from the metal salt solution, but the provenance of interlamellar anions has to be discussed. If these anions are the counter anions of the metal salts they come from the same solution. If the preparation is performed at very high $\mathrm{pH}$ values, the interlamellar anion can be the hydroxyl anion coming from the alkaline solution. When the alkaline solution is a sodium or potassium carbonate, the intercalated anion is likely the carbonate ion because of its high selectivity for LDHs interlamellar domains. Moreover, when the preparation is performed at relatively high $\mathrm{pHs,}$ one has to exclude air borne $\mathrm{CO}_{2}$ in order to avoid carbonate contamination. Another way to 
intercalate a given anion is to prepare a solution of this anion in the reactor prior to the beginning of the co-precipitation. This synthetic route is often chosen as the method for preparing LDHs containing organic anions, which are difficult to synthesise in any other way.

Depending on the precipitation conditions, it is possible to obtain well-crystallised LDH phases or quasi amorphous materials. Some of the influencing experimental parameters are obvious, like:

- temperature in the reactor,

- $\mathrm{pH}$ of the reaction medium,

- concentration of metal salt solution,

- concentration of alkaline solution,

- flow rate of reactants,

- ageing of the precipitate,

while the other parameters are less obvious, such as:

- accumulation of electrolytes in the reaction medium,

- hydrodynamics of the dilution of reactive species, related to the stirring mechanism,

- geometry of the reactor including reactants injection pipes,

- complexation state of the metal cations. ${ }^{11}$

A supersaturated state is necessary to ensure the simultaneous precipitation of the cations; this is generally implemented by controlling the $\mathrm{pH}$ value of the solution. The co-precipitation should be carried out at a $\mathrm{pH}$ value not smaller than that at which the most soluble hydroxide is precipitated ${ }^{8}$ (Figure 4).

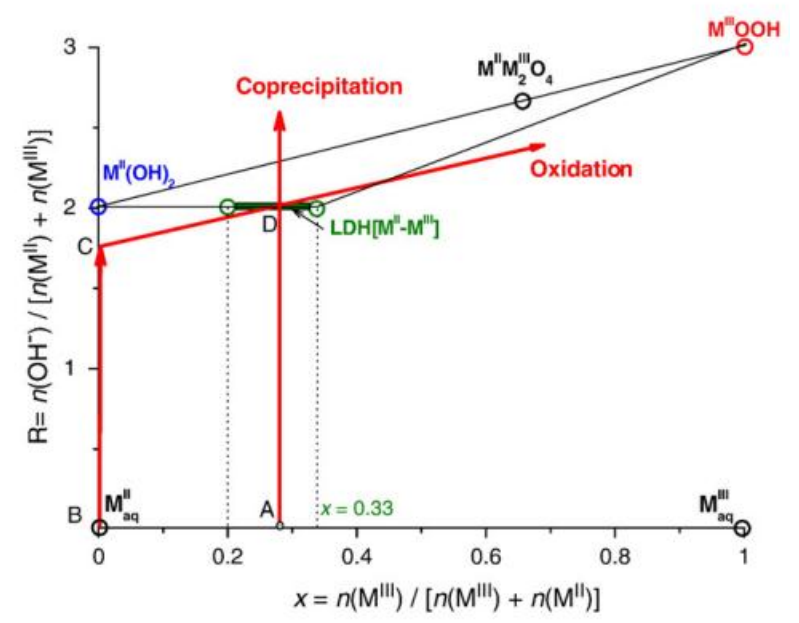

Figure 4. M(II)(MIII) mass-balance diagram showing the co-precipitation and oxidation synthesis routes. $^{39}$ 
A procedure using (hydro)thermal treatment following co-precipitation is often necessary to increase yields and/or the crystallinity of amorphous or poorly crystallised materials. A conventional ageing procedure is performed by heating the LDH suspension at temperatures in the range of $0-100{ }^{\circ} \mathrm{C}$ during several hours or even days. Two main co-precipitation methods have been commonly employed: (i) precipitation at constant $\mathrm{pH}$ value and (ii) at variable $\mathrm{pH}$ values.

In order to obtain well-defined phases, the operating conditions have to be optimised for each system.

\subsubsection{The urea hydrolysis method}

By using a base retardant as precipitating agent, the nucleation step can be separated from particle growth, and ageing is prevented from the beginning. Urea is a very weak Brønsted base $\left(\mathrm{pK}_{\mathrm{b}}=13.8\right)$ and can be employed as a reagent for "homogeneous" precipitation from solution. The hydrolysis of urea results in a solution with $\mathrm{pH}=9$, depending on the temperature, which is suitable for precipitating many metal hydroxides and a variety of LDHs. The urea hydrolysis method is suitable for the preparation of MgAl-LDHs with high layer charge densities. ${ }^{40}$ This method results in LDH crystallites with a relatively large size (microns in diameter) and a well-defined hexagonal shape due to a low supersaturation during precipitation. ${ }^{41}$ The particle size can be controlled by altering the reaction temperature which affects the hydrolysis rate of urea and larger particles are formed at lower temperatures due to the lower nucleation rate. ${ }^{42}$ The disadvantages of this method that the as-synthesised LDHs usually contain carbonate ions, which generally cannot be deintercalated and that the LDHs containing metal ions that precipitate at higher $\mathrm{pH}$ are not possible to obtain.

\subsubsection{Anion-exchange method}

The anion-exchange method is based on the exchange properties of the interlayer anions. ${ }^{43}$ This method is especially useful when the co-precipitation method is inapplicable, for example, the divalent or trivalent metal cations or the anions involved are unstable in alkaline solution, or the direct reaction between metal ions and guest anions is more favourable, or there is no suitable soluble salt of the guest anions. In thermodynamic terms, anion exchange in LDHs depends mainly on the electrostatic interactions between the host sheets and the exchanging anions and, to a lesser extent, on the free energy associated with the changes of hydration. ${ }^{43,44}$ Another important remark is that the equilibrium constant increases when the ionic radius of the bare anion decreases. Exchange is therefore favoured 
for in-going anions with a high charge density. From calculations of the equilibrium constant of various exchange reactions, Miyata ${ }^{45}$ gave a comparative list of ion selectivities for monovalent anions: $\mathrm{OH}^{-}>\mathrm{F}^{-}>\mathrm{Cl}^{-}>\mathrm{Br}^{-}>\mathrm{NO}_{3}{ }^{-}>\mathrm{I}^{-}$and for divalent anions: $\mathrm{CO}_{3}{ }^{2-}>$ $\mathrm{C}_{10} \mathrm{H}_{4} \mathrm{~N}_{2} \mathrm{O}_{8} \mathrm{~S}^{2-}>\mathrm{SO}_{4}{ }^{2-}$. Moreover, it appears that the selectivities of divalent anions are higher than those of the monovalent anions. According to these results, nitrate- and chloridecontaining LDHs appear to be among the best precursors for ion-exchange reactions. From a kinetic point of view, the rate-determining step of the reaction is the diffusion of the in-going anions within the interlayer, provided that the "infinite solution conditions" are respected. The diffusion of big anions inside the interlayer can be prevented by a too small basal spacing of the precursor. Exchange reactions via organic-anion-pillared precursors are then used. It has been verified that the favourability of the anion-exchange process is related to the following five main factors. (1) The exchange ability of incoming anions increases with increasing charge and decreasing ionic radius. The co-intercalation of a second anion was found to have no effect on the order of anion-exchange preference. ${ }^{46}$ (2) Appropriate choice of solvent will favour the swelling and anion exchange of an LDH precursor. ${ }^{47}$ (3) The $\mathrm{pH}$ value should generally be greater than 4 , in order to preserve the host hydroxyl layer against damage. A low $\mathrm{pH}$ value favours the liberation of anions of weak conjugate acids and incorporation of a less basic anion. ${ }^{48}$ (4) In some cases, the chemical composition of the LDH host layer affects the anion-exchange process. (5) Generally, higher temperatures favor anion exchange. ${ }^{49}$

\subsubsection{Dehydration-rehydration (reconstruction) method}

Miyata was the first to describe in 1980 the reconstruction of the original LDH structure by hydration of the calcined LDH. ${ }^{50}$ This unique property, ascribable to a structural memory effect, can be used as a general preparation method of LDH. In the first step the LDH is calcined into a mixture of oxides and then to rehydrated in an aqueous solution containing the anion to be intercalated (Figure 5).

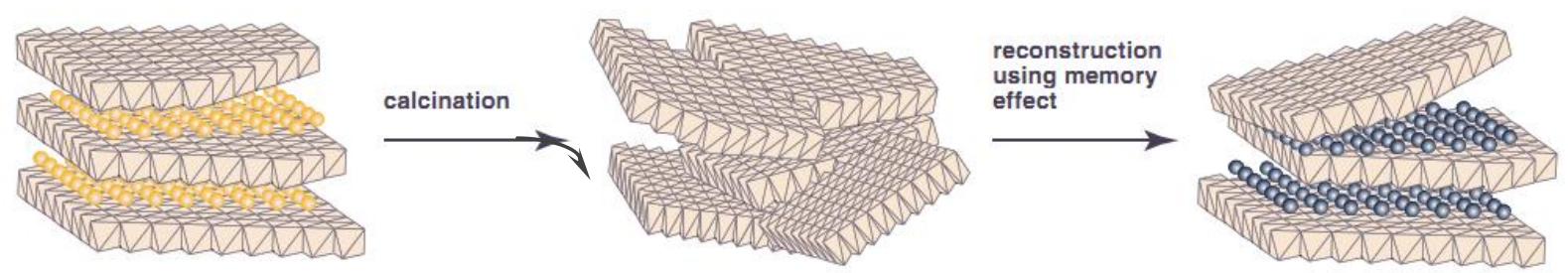

Figure 5. A simplified representation of the calcination/reconstruction method. 
The calcination conditions (temperature, rate, and duration of treatment) are important parameters determining structure recovery. Some limits of reversibility were observed. Repeated calcination/hydration cycles with hydrotalcite decrease the content of interlayer carbonate anions and increasing extraction the $\mathrm{Al}^{3+}$ from the brucite layers. ${ }^{51}$ The reconstruction method cannot be used for all $\mathrm{M}(\mathrm{II})-\mathrm{M}(\mathrm{III})$ combinations. Reconstruction of $\mathrm{Fe}^{3+}$-containing hydrotalcites is limited by the formation of $\mathrm{MgFe}_{2} \mathrm{O}_{4}$ spinel, which appears even at low $\mathrm{Fe}^{3+}$ content.

For most LDHs, during progressive calcination, four larger thermal events can be identified in general, and experimental evidence suggests that they can be resumed as follows: (1) continued dehydration process and dehydroxylation of layers between room temperature and $250^{\circ} \mathrm{C}$, (2) interlayer anion decomposition, between 250 and $350{ }^{\circ} \mathrm{C}$, with notable increases in the activation energy values, revealing the existence of different and simultaneous processes, (3) shrinkage and then collapse of the layered structure, between 350 and $550{ }^{\circ} \mathrm{C}$ and (4) the crystallisation of new phases. ${ }^{52}$ Spinel formed at temperatures around $1000{ }^{\circ} \mathrm{C}$ will not convert back to LDH by the memory effect, regardless of how hard one tries. The complexity of these stages implies that the separation of the contributory rate processes is difficult and kinetic analyses are complicated. The condensation of $\mathrm{OH}$ groups to form water molecules imply strong local reorganization leading to the collapse of the layered structure. This is probably a high-energy consuming step, which should be favoured by nucleation and growth of new phases at some local critical dehydration extension. After dehydroxylation quasi-amorphous mixed oxides are obtained, which crystallise progressively at higher temperatures, generally as a $\mathrm{M}(\mathrm{II}) \mathrm{M}(\mathrm{III})_{2} \mathrm{O}_{4}$ spinel-like phase and the divalent metal oxide. The ill-organised mixed oxides display three broad X-ray diffraction peaks generally corresponding to the future strongest lines of the spinel-like phase; they are therefore called pre-spinel oxides and it is not impossible that the transformation from the layered structure to this oxide phase could be topotactic. Generally, these mixed oxides display generally a relatively high specific surface $\left(100-300 \mathrm{~m}^{2} \mathrm{~g}^{-1}\right)$ compared to the as-prepared LDHs $\left(\approx 15 \mathrm{~m}^{2} \mathrm{~g}^{-1}\right)$.

This method is suitable for the preparation of hybrid LDH with large organic anions. An inert $\mathrm{N}_{2}$ atmosphere is required during the rehydration process when an anion other than carbonate is to be incorporated. It is difficult to obtain pure crystalline intercalated products because the lamellar structure of LDHs can often only be partially restored during the reconstruction stage. ${ }^{53}$ It has been found that the extent of intercalation observed using this method depends on (i) the reaction medium, (ii) the composition of the host layer, and (iii) the 
geometric and electronic structures of the anions. A wide range of anions, inter alia amino acids have been incorporated into layered double hydroxides using this method. ${ }^{54}$

Besides the methods for preparation discussed above, various other ways have been developed for the synthesis of LDHs, such as hydrothermal synthesis, ${ }^{55}$ the sol-gel process, ${ }^{56}$ a method involving separate nucleation and aging steps (SNAS) ${ }^{57}$ the salt-oxide (or salthydroxide) method, ${ }^{58}$ electrochemical synthesis, ${ }^{59}$ reverse microemulsion method ${ }^{60}$ etc. but they are used infrequently and only in special cases.

\subsection{Applications of layered double hydroxides}

Compositional diversity in the layers and in the interlayer anions leads to a functional diversity that allows LDHs to be used for a variety of material science applications.

\subsubsection{Catalytic applications}

As a result of their relative ease of synthesis, LDHs represent an inexpensive, versatile and potentially recyclable source for a variety of catalyst supports, catalyst precursors or actual catalysts. In particular, mixed metal oxides obtained by controlled thermal decomposition of LDHs have large specific surface areas, basic properties, a homogeneous and thermally stable dispersion of the metal ion components, synergetic effects between the elements, and the possibility of structure reconstruction under mild conditions. The thermal treatments at low temperature lead to synergetic effects between the elements in spinel-like or mixed oxide structures (e.g., $\mathrm{Mg}(\mathrm{Al}) \mathrm{O}$ mixed oxide with strong basic properties). The opportunity is thus offered for the fine control of the nature of the active sites and their environment, and the texture and the stability of the catalysts. This tailoring is supported by the lamellar structure, resulting from the moderate-temperature dehydration. In this case both the intercalated anion and the amount of remaining $\mathrm{H}_{2} \mathrm{O}$ determine the reactivity ${ }^{61}$ and the LDH behaves as a Brønsted-type catalyst and as such, it has been applied to aldol and Knoevenagel condensations, ${ }^{62,63}$ epoxidation of olefins, ${ }^{64}$ halide exchanges, ${ }^{65}$ phenol hydroxylation, ${ }^{66}$ Michael additions ${ }^{67}$ and transesterification. ${ }^{68}$ In these reactions the catalysts are mixed oxides obtained through the thermal decomposition of the LDH precursors. Those of the $\mathrm{Mg}(\mathrm{Al}) \mathrm{O}$-type have attracted much attention due to the presence of $\mathrm{Mg}^{2+}-\mathrm{O}^{2-}$ acid-base pairs leading to specific catalytic properties. They find applications in reactions as diverse as aldol, Claisen-Schmidt and Knoevenagel condensations, transesterification, alkylation of phenol by alcohols, oxidation of thiols, Baeyer-Villiger oxidation of ketones, polymerization of lactones, methanol synthesis, epoxidation of activated olefins with $\mathrm{H}_{2} \mathrm{O}_{2}$, and reduction of 
aldehydes and ketones by hydrogen transfer from alcohols. ${ }^{61,69}$ Some examples are detailed in the followings.

Industrial processes have hitherto used large amounts of liquid bases as catalysts for $\mathrm{C}-\mathrm{C}$ bond formation in condensation reactions. The replacement of these liquid bases by environmentally friendly basic solids with similar activities and selectivities is a real challenge. Basic oxides such as $\mathrm{MgO}, \mathrm{CaO}$ and $\mathrm{BaO}$ are very active in these reactions. The mechanism generally accepted for the aldol condensation of aldehydes and ketones involves first a hydrogen abstraction leading to the formation of an enolate-type species, then its condensation with another molecule, then the dehydration of the aldol thus formed to yield an $\alpha, \beta$-unsaturated compound. This mechanism shows that, aside from the basic sites of adequate strength, acid sites are also required for stabilising the enolate species, and for the dehydration. ${ }^{70}$ The balance between basic and acidic sites is thus a key parameter for the catalytic properties. Illustrations of the versatility of acid-base properties for catalytic application are, e.g., the aldolisation of acetone, Michael addition of nitromethane and cyclo2-en-1-one, and cross-condensation of heptanal and acetaldehyde. ${ }^{71}$

There are a lot of examples when the active catalyst results from the intercalation of specific anionic species in the interlayer space of the LDH, which is acting as the host structure. In the field of catalysis, their preparation has been claimed in order to fulfill the following objectives: (i) to obtain shape-selective chemical, electrochemical or photocatalysts, (ii) to stabilize homogeneous or biomimetic catalysts in order to increase their service life and allow easy recovery and recycling, and (iii) to prepare supported catalysts with concentrations of the active phase and activities higher than those obtained with conventional supports. Although an LDH is seemingly a weak base, intercalation of acidic anions (such as many polyoxometallate - POM anions) makes it simultaneously possess acidity, which has been well demonstrated in the epoxidation of various olefins. Most interesting is the variation of transition metal ions in the brucite-like layer that enables LDHs to show a spread spectrum of catalytic activity for oxidation and reduction, which has been examplified in the applications for total oxidation of volatile organic compounds, $\mathrm{H}_{2}$ production, $\mathrm{DeNO}_{\mathrm{x}}$ and $\mathrm{DeSO}_{\mathrm{x}}$ reactions and CNT formation. ${ }^{72}$ It has been demonstrated that both calcined and uncalcined LDHs are effective supports for noble metal catalysts. ${ }^{73,74}$ For example, palladium supported on calcined MgAl-LDH has been used for the one-pot synthesis of 4-methyl-2-pentanone (methyl isobutylketone) from acetone and hydrogen at an atmospheric pressure. ${ }^{75}$ Choudary et $a l .^{76}$ studied $\mathrm{Pd}(0)$ catalysts supported on $\mathrm{MgAl}-\mathrm{LDHs}$ prepared by ion-exchange with $\mathrm{PdCl}_{4}{ }^{2-}$, followed by reduction. They observed that the catalysts, used in ionic liquids, not 
only exhibited higher activity and selectivity than the homogeneous $\mathrm{PdCl}_{2}$ system in the Heck olefination of electron-poor and electron-rich chloroarenes, but also showed superior activity in the $\mathrm{C}-\mathrm{C}$ coupling reactions of chloroarens compared with other heterogeneous catalysts involving $\operatorname{Pd}(0)$ on supports such as silica, alumina or Merrifield's resin. Intensively investigated polyoxometallate-based (POM) and sulphonato-salen-based (Salen) catalysts have been intensively invetigated for oxidising $\mathrm{C}=\mathrm{C}$ double bonds with $\mathrm{H}_{2} \mathrm{O}_{2}$ or oxygen over a homogeneous or heterogeneous catalyst in systems free of organic solvent. These two catalytic anions can be intercalated and thus confined in the interlayer spacing of LDHs, which leads to high activity and selectivity for epoxidation of various olefins. ${ }^{37}$ Since POMs are restricted in the interlayer or on the surface, only part of the anion is exposed to reactants, which probably causes the regioselective epoxidation of one $\mathrm{C}=\mathrm{C}$ bond over another in the same organic molecule, and stereoselective epoxidation of a $\mathrm{C}=\mathrm{C}$ bond to form a specific stereostructure. Stereo- and regioselectivities have been observed in the epoxidation of terpene, 3-carene, squalene and (-)-carveol. ${ }^{77} \mathrm{ZnAl-LDHs}$ intercalated with sulphonato-salen$\mathrm{Mn}, \mathrm{Fe}$ or Co complex anions have also demonstrated high activity and selectivity in the epoxidation of various olefins. These catalysts are able to convert 95-100\% of (+)-limonene and (-)- $\alpha$-pinene with nearly $90 \%$ selectivity to the relevant epoxides in various solvents with $\mathrm{O}_{2}$ or air as the oxidant at room temperature. ${ }^{78}$ The secondary and tertiary amines can be oxidised with various oxidising reagents over the catalyst with a certain alkalinity. $\mathrm{MgAl}-$ $\mathrm{LDH}$ is a weak base, and can be made stronger by intercalating $\mathrm{OBu}^{-}$anion. ${ }^{79}$ It showed an activity similar or superior to $\mathrm{KOBu}$ and $\mathrm{NaOH}$ for $\mathrm{N}$-oxidation of $\mathrm{N}$-methylmorpholine and dibutylamine using $\mathrm{H}_{2} \mathrm{O}_{2}$ as the oxidant in benzonitrile-methanol. Several secondary and tertiary amines were readily $\mathrm{N}$-oxidized with high yields (72-98\%). It seems that $\mathrm{N}$-oxidation of tertiary amines is much faster than secondary amines, since the tertiary amines are almost quantitatively $\mathrm{N}$-oxidised with $\mathrm{H}_{2} \mathrm{O}_{2}$ over $\mathrm{WO}_{4}-\mathrm{MgAl}-\mathrm{LDH}$ under similar conditions $(95 \%$ yield). ${ }^{80}$ These LDH-based catalysts are all recyclable, without any obvious loss of activity.

Research involved coating $\mathrm{LDH}$ particles onto magnetic $\mathrm{Fe}_{3} \mathrm{O}_{4}$ particle surface to form a core-shell structure. The calcined $\mathrm{LDH} / \mathrm{Fe}_{3} \mathrm{O}_{4}$ composite particles were then immersed in $\mathrm{W}_{7} \mathrm{O}_{24}{ }^{6-}$ solution to load this POM during reconstruction of the $\mathrm{LDH}$ phase. This magnetically recoverable $\mathrm{POM}-\mathrm{LDH} / \mathrm{Fe}_{3} \mathrm{O}_{4}$ composite catalyst showed high photocatalytic activity for the decomposition of hexachlorocyclohexane under visible light emitted from high-pressure mercury lamp, and the activity was unchanged even after cycling for 6 times. ${ }^{81}$ Layered double hydroxides may also be useful support precursors ${ }^{8,82,83}$ of Ziegler-Natta catalysts for ethylene polymerization or $\mathrm{DESO}_{\mathrm{x}}$ additives to FCC catalysts, showing high 
stability also under severe reaction conditions, and excellent catalytic properties as well as easy regeneration. The more detailed description of the chosen reactions for catalytic testing studies is given in Chs. 5.3. and 5.4., pp. 60-71.

\subsubsection{Environmental applications}

Recently, since serious contamination of water arises from various anionic compounds, and cultivated soils extensively develop acidic property, attempts to remove anionic ions and pesticides by adsorption to LDHs have steadily increased. LDH can take up a variety of contaminants and toxic substances directly from the environment through anion exchange, reconstruction, and adsorption.

Phosphate, a causative factor in surface water eutrophication, can be captured by the chloride or nitrate forms of $\mathrm{LDH}$ through ion exchange. ${ }^{84,85}$ Competing anions affect phosphate uptake. For example, nitrate causes only a slight decrease in phosphate removal whereas sulphate brings about $12-13 \%$, and carbonate does $33 \%$, reduction.

A few studies have been carried out to develop the potential of LDHs as plant nutrients, pesticides, growth regulators, and active component in animal feeds. ${ }^{86,87}$

Only a few of natural antibiotic substances are available for pest control mainly because of their inherent properties such as easy degradability, high minimum inhibition concentration for practical application and often extremely low availability. The hybridisation of natural antibiotic substances with layered double hydroxides could be an alternative for green formulation of pesticides. ${ }^{88}$

Humic substances constitute a major fraction of organic matter in natural water and effluents from lakes and rivers. Their presence has been a problem in the water industry and in environmental purification such as soil remediation. During the removal process of heavy metal contaminants in soil remediation and the removal process of organic pollutants in drinking water treatment, humic acids often reduce the removal of the target substances through their adsorption onto adsorbents and/or a formation of a complex with the target substances. The removal of the humic compound by conventional adsorbents is, however, difficult due to their good solubility in water and their wide range of distribution in molecular weight and size. Layered double hydroxides are ideal choice for the removal of the humic substances, their removal occurs by both the intercalation into the positively charged innerlayer (ion-exchange) and the adsorption onto hydroxyl groups of the layers. ${ }^{89}$ The main advantages of LDHs over the conventional anion exchange resins include their higher anion- 
exchange capacity for certain oxy anions and their good thermal stability. Furthermore, LDHs can be fully regenerated in a short time for reuse.

Adsorption of carbon dioxide onto LDH was investigated as a possible method for recovery of $\mathrm{CO}_{2}$ from hot gas streams. ${ }^{90,91}$ The recovery of $\mathrm{CO}_{2}$ from power-plant flue gases is considered to be the first step in reducing total $\mathrm{CO}_{2}$ emission. The carbon dioxide adsorption capacity of LDH is dependent on the micropore volume, interlayer spacing, and layer charge density of the material.

\subsubsection{Additives for polymers}

The incorporation of a polymer in the interlayer galleries may proceed via various pathways such as co-precipitation, ion exchange, surfactant-mediated incorporation, hydrothermal treatment, reconstruction, or delamination followed by restacking. ${ }^{92}$ Alternatively, various monomers can be intercalated and polymerised in situ within the interlamellar space of $\mathrm{LDH}$. This method requires appropriate monomers. To date, intercalation of polyacrylate, polyaniline, poly(aminobenzoate) and poly $(\alpha, \beta$-aspartate) have been reported. ${ }^{93,94,95}$ The spatial confinement is believed to increase the degree of polymerisation, and, in addition, this type of in situ radical polymerisation process makes it possible to tune the tacticity and the molecular weight of the resulting polymer by varying the layer-charge density and the particle size of the host structure, respectively.

From several studies, it has been observed that the multicomponent LDH/polymer systems are thermally more stable than the pristine inorganic compounds, leading to potential applications such as flame-retardant composites. From an environmental standpoint, LDHbased flame retardants are preferable to their halogen-based counterparts. Many flame retardants are considered harmful, having been linked to liver, thyroid, reproductive or developmental, and neurological effects In flame-retardancy tests, LDHs are superior to other inorganic hydroxides, such as magnesium and aluminium hydroxides. ${ }^{96}$ A throughout review on the topic was given by Taviot-Guého and Leroux. ${ }^{97}$

The literature regarding polymers with LDH additives is even more extensive. Now, the LDHs are the guest materials (in previous paragraphs they were the matrices) and many mechanical properties of the resulting polymer-nanocomposite (e.g., strength and heat resistance, gas permeability and flammability, biodegradability, etc.) did improve with the modification. ${ }^{98}$ These nanocomposites are prepared from the delamination of the hydroxide sheets in a polymer matrix. ${ }^{99}$ Synthetic LDHs are commercially used as acid neutralisers or $\mathrm{HCl}$ scavengers in stabiliser packages for poly(vinylchloride) (PVC). PVC undergoes 
autocatalytic dehydrochlorination when exposed to heat or UV light, becoming brittle and changing colour. Mori et al. ${ }^{100}$ reported that adding LDH to PVC in the presence of 6-anilino1,3,5-triazine-2,4-dithiol and zinc stearate, jointly used as a stabiliser, reduces the rate of PVC discoloration. From the viewpoint of this work these type of applications have lower importance, if a deeper insight is needed, please consult with the review of Kumar et al. ${ }^{101}$

\subsubsection{Pharmaceutical and cosmetic applications}

Pharmaceutical applications of LDHs mainly rely on their acid buffering effect and anion-exchange properties. Hydrotalcite-derived antacidic and antipeptic formulations are representative of their applications in pharmaceutics. Hydrotalcite has also found pharmaceutical applications as an ingredient in sustained-release pharmaceuticals containing nifedipine, for stabilising pharmaceutical composition, and for preparing aluminium magnesium salts of antipyretic, analgesic and anti-inflammatory drugs. ${ }^{102}$ One principal area that has been the focus of intense research in recent years is the use of LDH hosts as storage and delivery devices for biologically important species. A number of important bioactive species are based on carboxylic acids, and hence are suitable for intercalation into LDHs. Furthermore, the wide variety of cations that can comprise an LDH mean that it is facile to

produce biocompatible materials. A variety of drugs have been incorporated into LDHs. ${ }^{103,104}$ It is a long-term goal of pharmaceutical scientists to develop so-called 'controlled release formulations' (CRFs). These are advantageous over current methods of drug delivery: instead of taking doses of the drug regularly at given time intervals, CRFs allow the patient to take only tablets far less frequently. Delivery of the drug is slow and sustained, and an effective and non-toxic concentration of the drug may be retained in the body over a long period of time. With traditional formulations, the drug concentration is in the effective region for a relatively short period of time, at either side the concentration may be dangerously high or ineffectively low. Choy et al. have made very significant contributions to this area. $\mathrm{Mg}_{2} \mathrm{Al}-$ LDH was successfully employed to intercalate folic acid and methotrexate (MTX), both commonly used to treat cancer sufferers. ${ }^{104}$ An in vitro bioassay was used to demonstrate that in the initial stages after administration of the drug, MTX- $\mathrm{Mg}_{2} \mathrm{Al}-\mathrm{LDH}$ has a significantly higher efficacy against tumor cells than MTX alone. This could be because the LDH matrix allows MTX to pass through the cell membrane more effectively, and also prevents decomposition of the drug in the cell plasma. However, it is not exactly clear how this could occur. The LDH is not simply acting as a delivery matrix, but is also improving the efficiency of the drug. Another recent development is the synthesis of LDHs intercalated with $\beta$ - 
cyclodextrins. ${ }^{105}$ These bowl-like molecules can be used to contain lipophilic drug molecules, thereby increasing their stability, water solubility and bio-availability. LDHs can intercalate many important negatively charged biomolecules such as oligomers, single or double stranded DNA, and simple molecules like nucleotides. ${ }^{106,107}$ Especially, the single or double stranded DNAs have a great deal of application potentials in various fields, expanding from gene therapy to biosensing and even high density information storage. However, DNA strands are very susceptible to degradation and denaturation occurring during manufacture processes and storage. The intercalated DNA on the other hand was safely protected against harsh condition including strong alkaline, weak acidic environments and DNase attack. ${ }^{107}$ It could also be recovered very easily by exposing DNA-LDH hybrids to an acidic condition due to the solubility of LDHs in acid, implying promising potential of LDHs in biological applications. Further experiments have shown that vitamins may also be intercalated and discharged in a controlled fashion. ${ }^{108}$ In vivo studies have demonstrated that LDH particles have little systematic effect at low doses, and thus are likely to be suitable as drug delivery matrices. ${ }^{109}$

LDHs possess many fascinating features to be also applied in cosmetics like high adsorption capacity, excellent anion-exchange ability and stabilising potentials. For example, the high adsorption capacity can be used to remove skin exudates and to encapsulate skin sensitive colouring and UV-screening agents, while the anion-exchange ability can be useful to protectively deliver active substances for anti-wrinkling and skin regeneration. LDHs stabilise unstable molecules such as retinoic acid, ascorbic acid, tocopherol, etc. often used in cosmetics and can improve rheological properties of various formulations, especially emulsions. Even if the practical application of LDHs in cosmetics is not much developed, there are some studies in which the potentials of LDHs for cosmetic purposes were explored. ${ }^{110,111,112}$ 


\section{THE MAIN AIMS OF THE DISSERTATION}

Layered double hydroxides have a wide range of compositions which give rise to the possibility of fine-tuning their properties in a variety of ways, allowing improved applications in many areas. At the beginning of my work several goals were set out:

- Exploring and finding the optimum experimental conditions for the synthesis of pristine $\mathrm{Ca}(\mathrm{II}) \mathrm{Fe}(\mathrm{III})$ - and $\mathrm{Mg}(\mathrm{II}) \mathrm{Fe}(\mathrm{III})-\mathrm{LDHs}$, representatives of hydrocalumite and hydrotalcite structural types, respectively.

- Characterising these materials with as many methods as it is possible.

- Studying the catalytic activity of the pristine, uncalcined CaFe-LDH.

- Functionalising CaFe-LDH via intercalating aromatic, partially or fully saturated $\mathrm{N}$-containing heterocycles - studying the effects of changing the solvents on the intercalation and characterising the obtained organic-inorganic hybrid substances.

- Functionalising chloropropylated silica gel at the N- or the C-terminal.

- Comparing the catalytic activities of the L-prolinate- and DL-pipecolinate-CaFeLDH samples with those of the L-proline-functionalised silica gel samples and (a purchased) L-prolinol-functionalised resin. 


\section{EXPERIMENTAL PART}

\subsection{Materials}

All materials used for experiments [calcium chloride $\left(\mathrm{CaCl}_{2}\right.$, Molar Chemicals, puriss), magnesium chloride $\left(\mathrm{MgCl}_{2} \cdot 6 \mathrm{H}_{2} \mathrm{O}\right.$, Molar Chemicals, a.r. grade), iron chloride $\left(\mathrm{FeCl}_{3} \cdot 6 \mathrm{H}_{2} \mathrm{O}\right.$, Molar Chemicals, puriss special) hydrogen chloride $(\mathrm{HCl})$, sodium hydroxide $(\mathrm{NaOH}, \mathrm{VWR}$, a.r. grade) potassium hydroxide (KOH, Reanal, a.r. grade), (S)-pyrrolidine-2-carboxylic acid (L-proline, Sigma-Aldrich, $\geq 99 \%$ ), DL-2-piperidine-carboxylic acid (DL-pipecolinic acid, Sigma-Aldrich, $\geq 99 \%$ ), (S)-(-)-indoline-2-carboxylic acid (dihydroindole-2-carboxylic acid, Sigma-Aldrich, $\geq 99 \%$ ), indole-2-carboxylic acid (Sigma-Aldrich, $\geq 98 \%$ ), sodium dodecylbenzenesulphonate (DBS, Sigma-Aldrich, technical grade) tert-butoxy-carbonyl-Lproline (Boc-Pro-OH, Sigma-Aldrich, a.r. grade), L-proline methylester (H-Pro-OMe, Sigma-Aldrich, a.r. grade) chloropropylated silica gel (SG, Sigma-Aldrich, a.r. grade, particle size: 230-400 mesh, BET surface area: $500 \mathrm{~m}^{2} / \mathrm{g}$, functionalisation: $8 \%$ )] were used as received without further purification. The resin-anchored L-prolinol-2-chlorotrityl ether was also a commercial product (Sigma-Aldrich, particle size: 200-400 mesh, extent of labeling: 0.3-1 mmol/g loading). The resin in the acid-labile chlorotrityl resin is polystyrene crosslinked with $1 \%$ divinyl benzene. Dichloromethane $\left(\mathrm{CH}_{2} \mathrm{Cl}_{2}\right.$, Reanal), trifluoroacetic acid $\left(\mathrm{CF}_{3} \mathrm{COOH}\right.$, Reanal) and sulphuric acid $\left(\mathrm{H}_{2} \mathrm{SO}_{4}\right.$, CarloErba $\left.96 \%\right)$ were used for removing the protecting groups. The solvents [acetone (Sigma-Aldrich, $\geq 99.5 \%$ ), methanol (Sigma-Aldrich, 99.93\%), ethanol (VWR, $\geq 96 \%$ ), 2-propanol (Molar Chemicals, a.r. grade) 2-methyl-2propanol (Sigma-Aldrich, $\geq 99.5 \%$ ), formamide (Reanal, a.r. grade), 1,4-dioxane (Reanal, a.r. grade), cyclohexene (Reanal, a.lt. grade), n-hexane (Reanal, a.lt. grade), dimethyl sulphoxide (DMSO, Merck, 99.7\%)] were also used without further purification. Filtered and ion exchanged water (Millipore) was applied throughout the experiments.

The reagents used for the catalytic reactions [hydrogen peroxide $\left(\mathrm{H}_{2} \mathrm{O}_{2}, 30 \mathrm{wt} \%\right), 2$ cyclohexen-1-one, benzaldehyde, 2-nitrobenzaldehyde, 4-nitrobenzaldehyde and 2-thiophene carbaldehyde] were Sigma-Aldrich products. All these compounds were of analytical grade and were used without further purification except the liquid aldehydes, which were freshly distilled before use. 


\subsection{Preparation of concentrated and carbonate-free $\mathrm{NaOH}$ solution}

The preparation of the concentrated $[\mathrm{c} \approx 20 \mathrm{M}]$ and carbonate-free sodium hydroxide solution was carried out by dissolving solid $\mathrm{NaOH}$ in water ( 1:1 mass ratio). After precipitating the sodium carbonate, the solution was filtered on polysulphone Nalgene filter. ${ }^{113}$ The exact density of the solution was determined by a pycnometer. The concentration of the solution was calculated from the known density $v s$. concentration curve of sodium hydroxide. ${ }^{114} \mathrm{NaOH}$ solutions of various concentrations were made from this stock solution just before the synthesis.

\subsection{Synthesis of the layered double hydroxides}

The $\mathrm{Ca}(\mathrm{Mg}) \mathrm{Fe}-\mathrm{LDH}$ s were prepared by the co-precipitation method via dropwise addition of the two metal salt solutions with various molar ratios (M(II): $\mathrm{Fe}(\mathrm{III})$ ranging from 6 to 2) to hot ( $c a .80{ }^{\circ} \mathrm{C}$ ), vigorously stirred and $\mathrm{N}_{2}$-blanketed $\mathrm{NaOH}$ solution. The precipitates formed were rapidly filtered until air dry in a $\mathrm{CO}_{2}$-free atmosphere, with the aid of a caustic resistant vacuum filter unit (Nalgene) equipped with an appropriate membrane (Versapor, $0.45 \mu \mathrm{m}$ ). The solid material was washed and filtered and the obtained crystals were kept at room temperature in a desiccator over $\mathrm{P}_{2} \mathrm{O}_{5}$.

\subsection{Intercalation of the layered double hydroxides}

The anions of various $\mathrm{N}$-containing carboxylic acid, aromatic (indol-2-carboxylate), partially ((S)-(-)-indoline-2-carboxylate) or fully saturated (L-prolinate, DL-pipecolinate) heterocycles were intercalated into $\mathrm{Ca}_{3} \mathrm{Fe}-\mathrm{LDH}$ with the dehydration-rehydration method, utilising the memory effect of the layered double hydroxides (for the structures of organic anions, see Figure 6).

A typical recipe is as follows. The pristine CaFe-LDH was heat-treated at $773 \mathrm{~K}$ for $5 \mathrm{~h}$ in $\mathrm{N}_{2}$ atmosphere. A portion of the obtained dehydrated material was suspended in $80 \mathrm{~cm}^{3}$ solvent mixture (ethanol $/ \mathrm{H}_{2} \mathrm{O} / \mathrm{NaOH}$ or acetone $/ \mathrm{H}_{2} \mathrm{O} / \mathrm{NaOH}$ both with $1: 5: 1$ volume ratios), which also contained the heterocyclic compounds in a high excess (usually $10: 1$ molar ratio for the $\mathrm{Fe}(\mathrm{III})$-content of the LDO), after inert $\mathrm{N}_{2}$ was bubbled through the mixture. The reaction mixture was stirred for a week at $60{ }^{\circ} \mathrm{C}$. The solid catalyst was filtered and washed with water. The crystals obtained were kept at room temperature in a desiccator over $\mathrm{P}_{2} \mathrm{O}_{5}$. 
<smiles>O=C(O)c1cc2ccccc2[nH]1</smiles>

indol-2-carboxylic acid

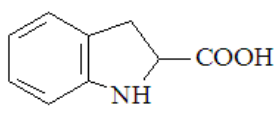

(S)-(-)-indoline-2carboxylic acid

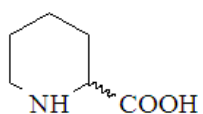

DL-2-piperidinecarboxylic acid

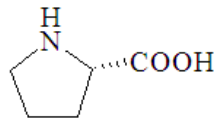

L-proline

Figure 6. The structures of the intercalated organic anions (for simplicity, protons are uniformly shown to be attached to the carboxylate groups).

\subsection{Immobilisation of $L$-proline in functionalised chloropropylated silica gel}

The N-protected or C-protected L-proline was covalently grafted onto the modified silica gel surface with esterification (tert-butoxycarbonyl-L-proline) or $\mathrm{N}$-alkylation (L-proline methylester) reactions. After $24 \mathrm{~h}$ reflux in a basic isopropanolic suspension (KOH was used) the materials obtained were filtered washed and dried. Then, the protecting groups were removed. The ester was hydrolysed with sulphuric acid ( $2 \mathrm{~h}$ reflux), while the tertbutoxycarbonyl group was removed via a $2 \mathrm{~h}$ reflux under vigorous stirring at moderate temperature $(338 \mathrm{~K})$ in a 1:1 mixture of $\mathrm{CH}_{2} \mathrm{Cl}_{2}$ and $\mathrm{CF}_{3} \mathrm{COOH}$.

\subsection{Heterogeneous catalytic reactions}

The pristine as-prepared layered double hydroxides were tested in the epoxidation of electron-deficient carbon-carbon double bonds of an $\alpha, \beta$-unsaturated ketone (2-cyclohexen-1one) using $30 \mathrm{wt} \%$ aqueous hydrogen-peroxide as oxidant under mild reaction conditions (vigorous stirring at $298 \mathrm{~K}$ for $2 \mathrm{~h}$ ) applying various solvents (methanol, ethanol, 2-methyl-2propanol, acetone, formamide, 1,4-dioxane, cyclohexene, n-hexane). Temperature dependence (288-343 K range) was also examined. The catalytic properties of intercalated derivatives (indole-2-carboxylate- $\mathrm{Ca}_{3} \mathrm{Fe}-\mathrm{LDH}$ and $\mathrm{L}$-prolinate- $\mathrm{Ca}_{3} \mathrm{Fe}-\mathrm{LDH}$ ) were also examined. The general conditions for the reactions were as follows: $1 \mathrm{mmol} 2$-cyclohexen-1one, $4 \mathrm{mmol} \mathrm{H}_{2} \mathrm{O}_{2}, 2.5 \mathrm{~mL}$ solvent, $0.075 \mathrm{~g}$ catalyst. Recycling and time dependence were also studied.

The catalytic activities of the L-prolinate- and DL-pipecolinate- $\mathrm{Ca}_{3} \mathrm{Fe}-\mathrm{LDH}$, the functionalised chloropropylated silicagel and functionalised resin samples were tested in the intermolecular cross-aldol dimerisation-condensation of acetone with various aldehydes (benzaldehyde - on all the solid materials, 2-nitro- and 4-nitrobenzaldehyde and 2-thiophene carbaldehyde - on the functionalised silica gel and resin samples). The reactions were run for $24 \mathrm{~h}$ at room temperature under vigorous stirring. Various solvents were used like water, DMSO or the acetone reactant itself. The composition of the initial mixture was generally as 
follows: $4-5 \mathrm{~cm}^{3}$ of solvent, $1-1 \mathrm{~cm}^{3}$ of the reactants (if the aldehydes were liquid) or $0.15 \mathrm{~g}$ when they were solid and $0.3 \mathrm{~g}$ of catalyst. Recycling study with the L-prolinate- $\mathrm{Ca}_{3} \mathrm{FeLDH}$ sample was also performed.

\subsection{Instrumentation and characterisation methods}

\subsubsection{X-ray diffractometry}

Powder X-ray diffraction (XRD) patterns of the air-dried and heat-treated solid samples were registered in the $2 \Theta=3-60^{\circ}$ range on Rigaku Miniflex II and DRON-2 instruments, using $\mathrm{CuK}_{\alpha}$ and $\mathrm{FeK}_{\alpha}(\lambda=1.5418 \AA$ and $1.9374 \AA$, respectively) radiations in BraggBrentano geometry. Reflection positions were determined via fitting a Gaussian function. They were found to be reproducible within $0.05^{\circ}(2 \Theta)$, therefore the uncertainty of the basal spacing was estimated as $\pm 0.01 \mathrm{~nm}$.

\subsubsection{Thermal analytical measurements}

Thermal analytical measurements (TG/DTG) were performed using a Setaram Labsys derivatograph working under $\mathrm{N}_{2}$ flow at $2{ }^{\circ} \mathrm{C} / \mathrm{min}$ heating rate. Both the weight loss vs. temperature (thermogravimetric - TG) and the differential weight loss vs. temperature (differential thermogravimetric - DTG) curves were recorded. Approximately $20 \mathrm{mg}$ sample (measured accurately into a ceramic crucible sample holder) was applied in each experiment. Measurements were started right after removing the samples from the desiccators.

\subsubsection{ICP-OES measurements}

Determination of the Fe(III) content of the LDH samples was done using a Thermo's IRIS Intrepid II ICP-OES spectrometer. The instrument was externally calibrated with a calibration solution series prepared from ICP Multielement standard solution XXIII made by CertiPUR.

\subsubsection{Microscopic techniques}

The morphology of the samples was examined with scanning electron microscope (SEM - Hitachi S-4700 microscope with varying acceleration voltage). The samples were ground before fixing them on a double-sided adhesive carbon tape. They were coated with gold in order to obtain images with more contrast, using a sputter coater (Quorum Technologies SC7620). The thickness of the gold layer was a few nanometers. The approximate 
composition and the elemental map of the substances were investigated by a Röntec QX2 energy dispersive X-ray fluorescence spectrometer (EDX) coupled to the microscope.

The layer thickness of the $\mathrm{Ca}_{3} \mathrm{Fe}-\mathrm{LDH}$ sample was estimated from a transmission electron microscopic (TEM) dark-field image taken by a FEI TECNAI G 20 X-TWIN microscope at $200 \mathrm{kV}$ accelerating voltage. Samples of the material to be analysed were suspended in absolute ethanol by means of and ultrasound bath, the mixture placed on a lacey carbon 200 mesh copper grid, and the solvent allowed to evaporate.

\subsubsection{Mössbauer spectroscopy}

${ }^{57} \mathrm{Fe}$ Mössbauer spectra of the samples were recorded with conventional Mössbauer spectrometers (Wissel and Ranger) in transmission geometry at $78 \mathrm{~K}$ or $295 \mathrm{~K}$. A ${ }^{57} \mathrm{Co} / \mathrm{Rh} \gamma-$ radiation source of $3 \times 10^{9} \mathrm{~Bq}$ activity was used. The spectrometers were calibrated with $\alpha$-iron at room temperature. Spectrum evaluation was carried out using the MOSSWIN code via fitting Lorentzian curves.

\subsubsection{XAS measurements}

The X-ray absorption spectra (XAS) were measured at beamline I511-3 (Figure 7) at the MaxLab facility, Lund, Sweden. The station is based on a superconductive undulator injection device connected to the $1.5 \mathrm{GeV}$ MAX II storage ring. X-ray radiation in the $50-1500 \mathrm{eV}$ energy range can be obtained from this system.

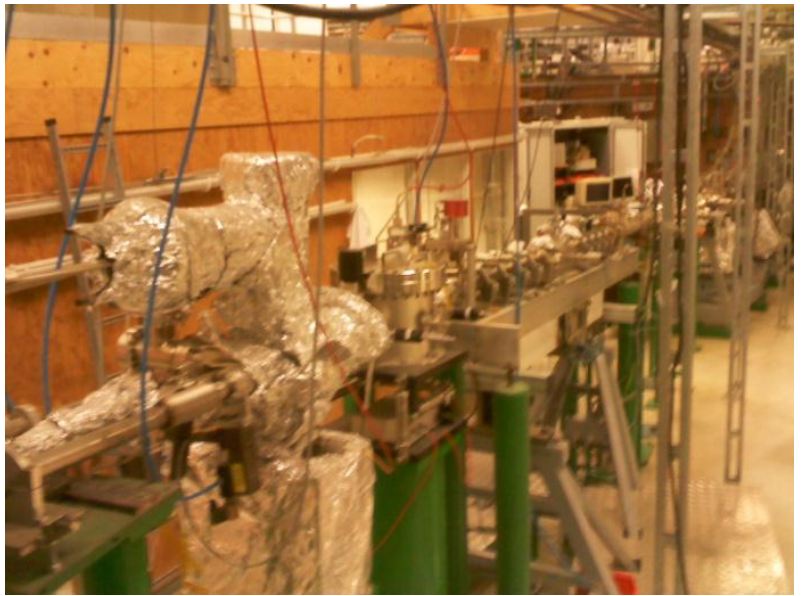

(a)

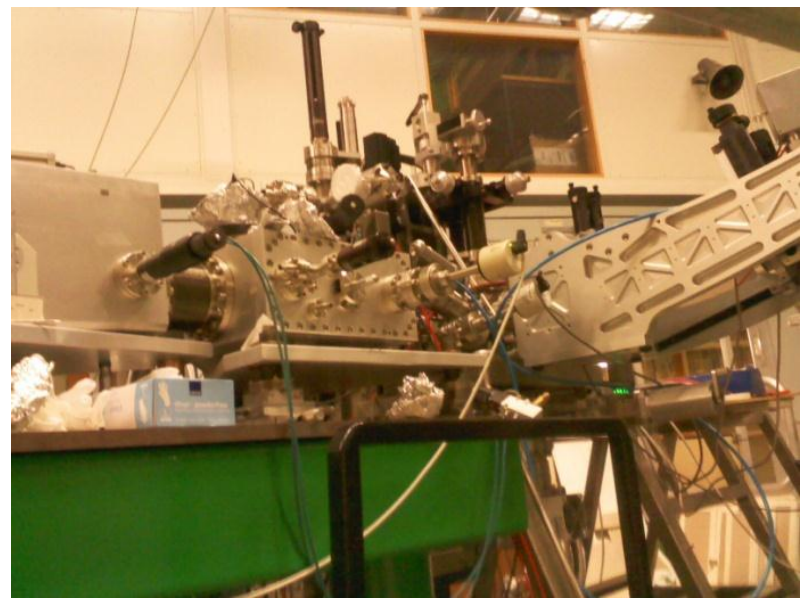

(b)

Figure 7. The 1511-3 station at MaxLab:(a) the beamline and (b) the spectrometers (for X-ray absorption emission).

Since this is not the method one uses on an every-day basis (except one is working at a synchrotron facility), the major characteristics of the method is described briefly in the followings. The fundamental phenomenon underlying XAS is the absorption of an X-ray 
photon by a core level of an atom in a solid and the consequent emission of a photoelectron. The absorption of the X-ray photon is based on the photo effect, i.e., the absorbed photon pushes out an electron from the inner shell of the bombarded atom or ion. The absorption coefficient decreases with the increase in energy, until it reaches the bonding energy of an inner electron. At this point a sharp peak appears in the spectrum. The corresponding energy is the so-called threshold energy. Beyond this energy a fine structure in the spectrum is seen up to even $10000 \mathrm{eV}$. The various regions of the $\mathrm{X}$-ray absorption provide different information.

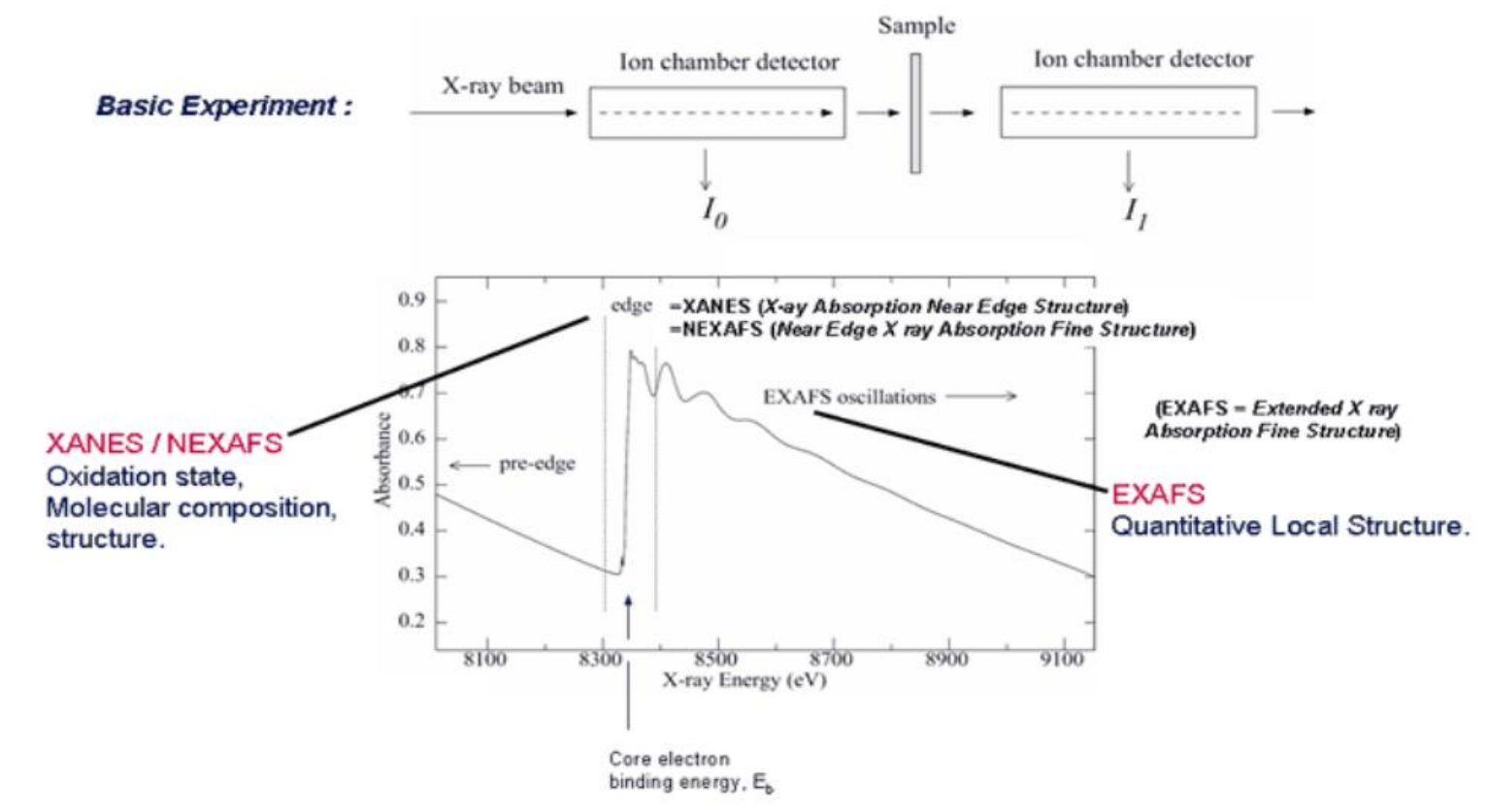

Figure 8. The various regions of the X-ray absorption spectrum (XANES - X-ray absorption nearedge structure, EXAFS - Extended X-ray absorption fine structure).

The part of the spectrum before the absorption edge is the pre-edge region. Information on the bonding character, the oxidation state and the coordination geometry of the element studied can be extracted from this part of the spectrum. Then, the absorption edge and its immediate surrounding follow - this is the XANES region. Both XANES and NEXAFS are acceptable terms for this part of the spectrum. The difference in usage is the energy range beyond the absorption edge. NEXAFS is synonymous with XANES, but NEXAFS by convention is usually reserved for soft X-ray spectroscopy photon energy less than 1000 electron volts. NEXAFS is generally used when applied to surface and molecular science, while XANES is used in most other fields. In the XANES region, starting about $5 \mathrm{eV}$ beyond the absorption threshold, because of the low kinetic energy range $(5-150 \mathrm{eV})$ the photoelectron backscattering amplitude by neighbouring atoms is very large, thus multiple scattering events become predominant in the XANES spectra. In the XANES region, the 
electron transfers occur to unoccupied bonding orbitals in most cases, and with much less probability to the continuum. Changes in this region may serve as a fingerprint for the materials. This region is the most sensitive to the changes in the geometry around the absorber atom or ion, i.e., very significant spectral changes may be observed. They are mainly due to the scattering of photoelectrons with low kinetic energies. Although in XANES the atoms/ions in the first coordination sphere predominate, other strongly bound scatterers have important effects as well. The last part is the EXAFS (Extended X-ray Absorption Fine Structure) region, from this region structural parameters like coordination number, bond lengths, etc. can be extracted. ${ }^{115}$

During a NEXAFS measurement the sample is irradiated with monochromatic X-rays. The energy of the X-rays is varied around the absorption edge. The predominant process in the soft X-ray energy range $(<2000 \mathrm{eV})$ is (by orders of magnitude) photoabsorption. Opposite to the related X-ray photoemission spectroscopy (XPS or ESCA) technique, where the photon energy is fixed and the electron intensity is measured as a function of electron kinetic energy, in NEXAFS the X-ray energy is scanned and the absorbed X-ray intensity is measured. NEXAFS spectra can be recorded in different ways, the most common methods are transmission and electron yield measurements. The transmission technique requires thin foils while the electron yield technique, often called total electron yield (TEY) detection, can be used for conventional samples. The absorbed X-ray intensity is not measured directly in TEY measurements, but rather the photoelectrons that are created by the absorbed X-rays. X-rays are absorbed through excitations of core electrons to empty states above the vacuum or Fermi level. The created holes are then filled by Auger decay (dominant in the soft X-ray region over X-ray fluorescence). The intensity of the emitted primary Auger electrons is a direct measure of the X-ray absorption process and is used in so called Auger electron yield (AEY) measurements, which are highly surface sensitive, similarly to XPS. As they leave the sample, the primary Auger electrons create scattered secondary electrons, which predominate in the total electron yield (TEY) intensity. The TEY cascade involves several scattering events and originates from an average depth, the electron sampling depth $L$. Electrons created deeper in the sample lose too much energy to overcome the work function of the sample and, therefore do not contribute to the TEY. The sampling depth $L$ in TEY measurements is typically a few nanometers, while it is often less than $1 \mathrm{~nm}$ for AEY measurements. In addition, electron detection provides the higher surface sensitivity and in the majority of studies published in the literature this detection scheme has been employed. The reason for the higher surface sensitivity is the relatively low kinetic energy of the electrons and the corresponding mean 
free path in matter, which is typically less than $1 \mathrm{~nm}$ for energies between $250 \mathrm{eV}$ and $600 \mathrm{eV}$. Although the X-ray photons penetrate many microns deep into the sample, the electrons generated at that depth do not emerge from the sample. The inelastic scattering process leads to an electron cascade, of which only those electrons with sufficient energy to overcome the work function of the material will escape the surface. The resulting effective escape depth - and therefore the information depth of electron yield NEXAFS - has been estimated to be in the range of $5 \mathrm{~nm}$ for metals and semiconductors, and slightly larger for insulators due to the reduced electron-electron scattering mechanism. The surface sensitivity can be further enhanced by applying a retarding voltage before the electrons enter the channeltron. By suppressing lower kinetic energy electrons, only those electrons that emerge from the outermost surface region $(\approx 3 \mathrm{~nm})$ are detected. For the investigation of adsorbates on surfaces, this so-called partial electron yield (PEY) detection has a better signal-tobackground ratio than total electron yield (TEY) detection, where all electrons that emerge from the surface are detected. A further option is Auger electron yield (AEY) detection, where only elastically scattered Auger electrons are recorded. The AEY mode requires an electron energy analyser but provides the best surface sensitivity of the three detection techniques. ${ }^{116}$

NEXAFS is element specific because the X-ray absorption edges of different elements have different energies, and it is also very sensitive to the bonding environment of the absorbing atom. Information concerning the orientation of the molecule can be inferred from using polarised X-ray irradiation.

Actually, the I511-3 beamline is dedicated to RIXS (Resonant Inelastic X-ray Scattering) measurements, the prerequisite of which is registering the X-ray absorption spectra. Here, I am going to give the parameters of this part, even though our longer term aim is to exploit the full potential of the experimental station. (The RIXS spectrum is measuring X-ray emission at the absorption edges and can provide more detailed structural information than the absorption spectrum alone.)

The X-ray absorption spectra of the pristine $\mathrm{Ca}_{3} \mathrm{Fe}-\mathrm{LDH}$ as well as the L-proline intercalated $\mathrm{Ca}_{3} \mathrm{Fe}-\mathrm{LDH}$ samples were registered around the $\mathrm{Ca} 1 \mathrm{~s}, \mathrm{Fe} 2 \mathrm{p}, \mathrm{O} 1 \mathrm{~s}$ and $\mathrm{N} 1 \mathrm{~s}$ absorption edges. The samples were inserted a high-vacuum chamber (the pressure was lower than $3.4 \times 10^{-8}$ mbar), and the spectra were recorded at $0.05 \mathrm{eV}$ steps around the absorption edges. Measurements were performed in the total fluorescence yield (TFY) mode and at various spots of the samples to avoid radiation damage. 


\subsubsection{UV-Vis spectroscopy}

The quantities of the intercalated anions (in the case of indole-2-carboxylate) were measured by UV-Vis spectroscopy. After the acidic degradation of the layers, the indole-2carboxylic acid concentration was determined at two different wavelengths $(218 \mathrm{~nm}$ and $292 \mathrm{~nm}$ ) in a Hewlett Packard 8452A diode array spectrophotometer. The extent of the intercalation is determined from the ratio of indole-2-carboxylate and Fe(III).

\subsubsection{FT-IR spectroscopy}

The Fourier-transform infrared (FTIR) spectra of the pristine, the organic anionintercalated LDH and the functionalised silica gel or resin samples were recorded on a BIORAD FTS-65A/896 spectrometer equipped with a DTGS detector in diffuse reflectance. Spectral resolution was $4 \mathrm{~cm}^{-1}$ and 256 scans were used for a spectrum. The spectra were baseline corrected and smoothed using the WIN-IR software package. The samples were finely ground and combined with $\mathrm{KBr}$ (without pressing into pellets).

\subsubsection{Molecular modelling}

The sizes of the various intercalated carboxylate ions were determined after performing full geometry optimisation with the PM3 semiempirical quantum chemical code included in the Hyperchem 8.0 molecular modelling package.

\subsubsection{Gas chromatography}

The epoxidation of 2-cyclohexen-1-one was followed by gas chromatography with the aid of a Hewlett-Packard 5890 Series II: instrument (50 m long HP-1 column, flame ionisation detector) using the internal standard technique.

The chemical compositions of the reaction mixtures after the intermolecular cross-aldol dimerisation-condensation of acetone were determined with an YL6100GC-6000 series gas chromatograph (30 m long Cyclosil B column, inner diameter: $0.25 \mathrm{~mm}$ ) working in the isothermal mode, at $383 \mathrm{~K}$. Product identification and quantitative analysis were done with mass selective and flame ionisation detectors, respectively. 


\section{RESULTS AND DISCUSSION}

\subsection{Preparation and characterisation of $\mathrm{Ca}(\mathrm{II}) \mathrm{Fe}(\mathrm{III})$ - and $\mathrm{Mg}$ (II)Fe(III) layered double hydroxides}

As it has been mentioned earlier, there are two main structural varieties in the family of layered double hydroxides. One is the group of hydrotalcites resembling the structure of brucite [layered $\left.\mathrm{Mg}(\mathrm{OH})_{2}\right]$. In this group the layers contain octahedrally coordinated two- and trivalent metal ions, the edge sharing octahedra are connected by the hydroxide ions. They are located at edges of the layers. The other one is the group of hydrocalumites. The divalent ion is the calcium ion here, and it is heptacoordinated, thus, the layer consists of edge-sharing heptacoordinated calcium hydroxide decahedrons and hexa-coordinated trivalent metal hydroxide octahedrons. In this section I concentrate on describing the optimum experimental conditions for the synthesis of pristine $\mathrm{Ca}$ (II)Fe(III)- and $\mathrm{Mg}$ (II)Fe(III)-LDHs, representatives of hydrocalumite and hydrotalcite structural types, respectively.

$\mathrm{Mg}(\mathrm{II}) \mathrm{Fe}(\mathrm{III})$ - and $\mathrm{Ca}(\mathrm{II}) \mathrm{Fe}(\mathrm{III})-\mathrm{LDHs}$ are already known from the literature, ${ }^{89,117,118}$ since we aimed at using them in intercalation studies, we needed more detailed information about their structural characteristics and the optimal synthetic conditions.

The preparation protocols were optimised through varying the $\mathrm{NaOH}$ concentrations, the ratio of the di- and trivalent ions, performing the synthesis in air or excluding the airborne $\mathrm{CO}_{2}$ by blanketing the reaction mixture with $\mathrm{N}_{2}$.
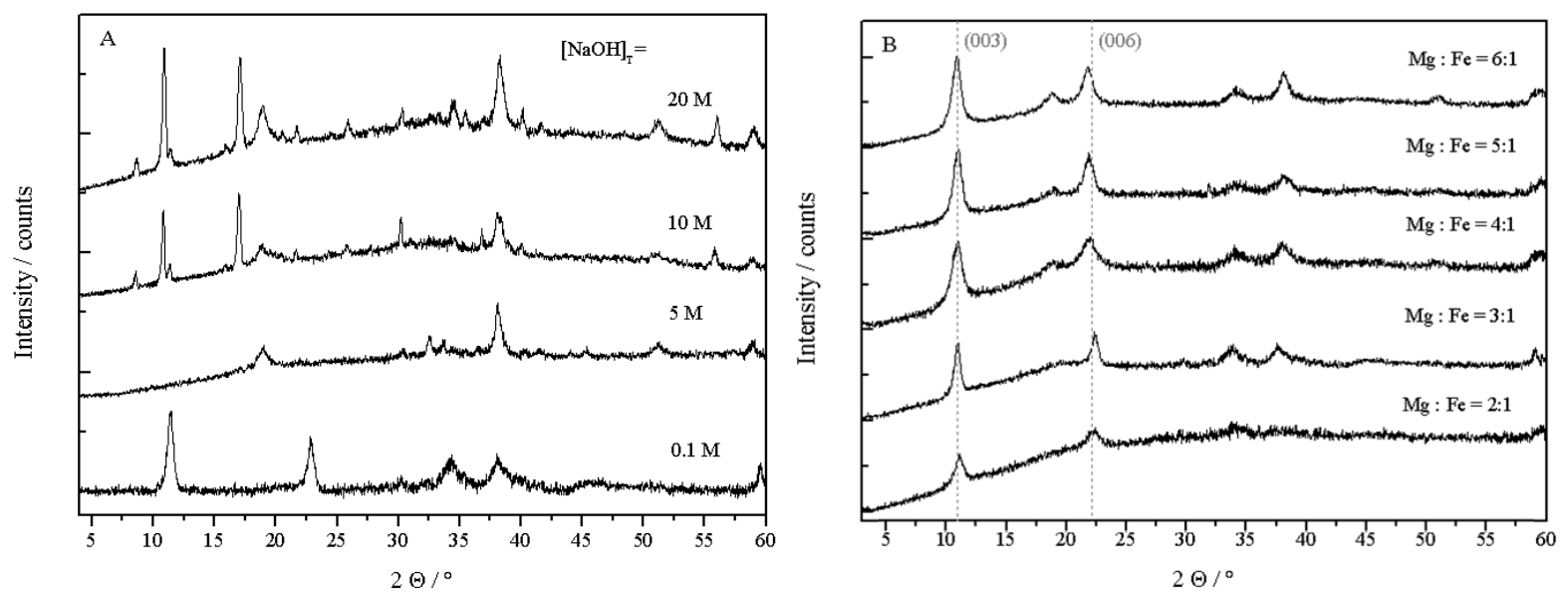

Figure 9. XRD patterns of the freshly prepared and air-dried $M g(I I)_{3} \mathrm{Fe}(I I I)-L D H$ with varying $\left[\mathrm{NaOH}_{T}(\mathrm{~A})\right.$ and varying $\mathrm{Mg} / \mathrm{Fe}$ ratio (B - The final $\mathrm{pH}$ value was 9.5 in the synthesis solution). 

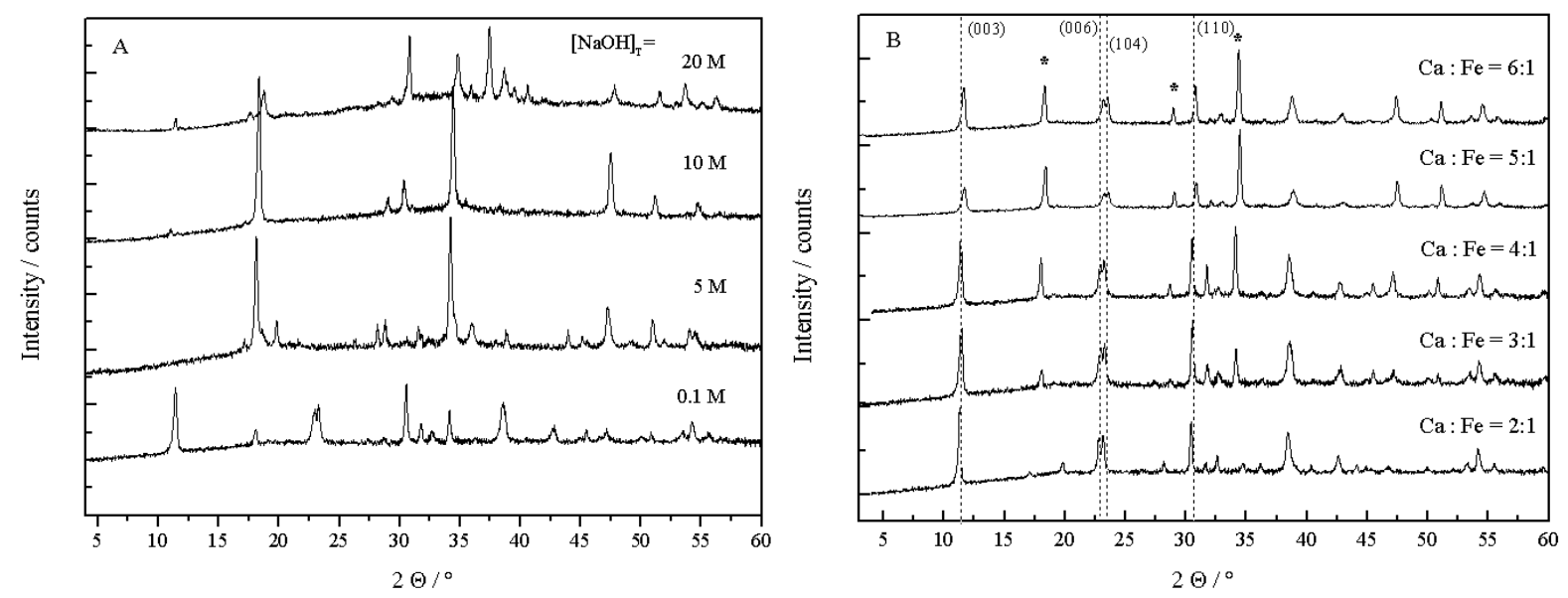

Figure 10. XRD patterns of the freshly prepared and air-dried $\mathrm{Ca}(\mathrm{II})_{3} \mathrm{Fe}(\mathrm{III})-\mathrm{LDH}$ with varying $\left[\mathrm{NaOH}_{T}(\mathrm{~A})\right.$ and varying $\mathrm{Ca} / \mathrm{Fe}$ ratio ( $B-$ The final $\mathrm{pH}$ value was 13 in the synthesis solution). Reflections associated with $\mathrm{Ca}(\mathrm{OH})_{2}$ side product are indicated with *.

The diffractogram consists of basal and non basal reflections. The basal reflections $(00 l)$ represent the thickness of an $l$ number of layers, each consisting of one octahedral metal layer and one interlayer. The typical reflections $(003,006)$ appearing on the diffractograms and most of the interlayer distances (calculated from the positions of the first reflections) in Table 1, prove that our syntheses were successful. Another important reflection is the (110), which represents the distance between two metal cations in the octahedral layer. The $a$-parameter of the crystal equals two times the d-spacing of the (110) reflection. ${ }^{119}$ The intensities of the non basal reflections are used to distinguish between the various polytypes.

As Figure 9. A) and Figure 10. A) attest the syntheses were not successful under highly alkaline $(5 \mathrm{M}, 10 \mathrm{M} \mathrm{NaOH})$ or hyperalkaline $(20 \mathrm{M} \mathrm{NaOH})$ conditions either because layered double hydroxides were not formed or because the ratio of secondary products was too high. However, when the final $\mathrm{NaOH}$ concentration was set to $0.1 \mathrm{M}$, the majority of the sole products were layered double hydroxides. In methods $\mathrm{A}$ and $\mathrm{B}$ the final $\mathrm{NaOH}$ concentrations were set to $3.16 \cdot 10^{-5} \mathrm{M}$ for $\mathrm{Mg}_{\mathrm{n}} \mathrm{Fe}-\mathrm{LDH}$ and $0.1 \mathrm{M}$ for $\mathrm{Ca}_{\mathrm{n}} \mathrm{Fe}-\mathrm{LDH}$, in methods $\mathrm{C}$, and $\mathrm{D}$ they were $1.875 \mathrm{M}$ and $2.55 \mathrm{M}$, respectively. In method $\mathrm{B} \mathrm{N}_{2}$-blanketing was applied.

XRD measurements confirmed the formation of LDH structures in Methods A, B and C. XRD patterns of the samples with different $\mathrm{Mg}(\mathrm{II}) / \mathrm{Fe}(\mathrm{III})$ ratio exhibited broad reflections corresponding to hexagonal LDH phase. Considerable ( $c a .10 \%)$ increase was found in the $\mathrm{d}(003)$ basal spacing values (from $0.798 \mathrm{~nm}$ to $0.823 \mathrm{~nm}$ ) as the $\mathrm{Mg}(\mathrm{II}) / \mathrm{Fe}(\mathrm{III})$ ratio was increased from 2 to 6.

The XRD traces revealed that $\mathrm{Ca}_{2} \mathrm{Fe}-\mathrm{LDH}$ was the only one that was phase pure, coinciding with the observation of Rousselot et $a l^{21}$ Here, all the reflections typical of a 
layered double hydroxide could be found and there were no other reflections. For the samples with higher $\mathrm{Ca}(\mathrm{II}) / \mathrm{Fe}$ (III) ratios new reflections showed up, which could clearly be assigned to a $\mathrm{Ca}(\mathrm{OH})_{2}$ phase. There was some increase in the $\mathrm{d}(003)$ basal spacing values with increasing $\mathrm{n}$ (it is though it is at the limit of detectability) verifying that LDH phase was always present in the samples (Table 1). The relative quantity of the $\mathrm{Ca}(\mathrm{OH})_{2}$ phase could also be estimated (Figure 11). On increasing $\mathrm{Ca}(\mathrm{II})$ to $\mathrm{Fe}(\mathrm{III})$ ratios from 2 to 6 , the quantity of $\mathrm{Ca}(\mathrm{OH})_{2}$ almost linearly increased from $0 \%$ to $\sim 60 \%$.

Table 1. Interlayer distance (d/nm) for $\mathrm{Mg}(\mathrm{II}) \mathrm{Fe}(\mathrm{III})-\mathrm{LDHs}$ and $\mathrm{Ca}(\mathrm{II}) \mathrm{Fe}(\mathrm{III})-\mathrm{LDH}$ s having various di-to trivalent metal ratios prepared following different synthesis protocols.

\begin{tabular}{cccccc}
\hline \multirow{2}{*}{ Method } & \multicolumn{5}{c}{$\operatorname{Mg}(\mathrm{II}): \mathrm{Fe}(\mathrm{III})$ molar ratio } \\
\cline { 2 - 6 } & $2: 1$ & $3: 1$ & $4: 1$ & $5: 1$ & $6: 1$ \\
\cline { 2 - 6 } & \multicolumn{5}{c}{ Interlayer distance, d/nm } \\
\hline A & 0.796 & 0.798 & 0.809 & 0.806 & 0.812 \\
B & 0.798 & 0.801 & 0.799 & 0.823 & 0.806 \\
C & 0.758 & 0.771 & 0.785 & 0.793 & 0.788 \\
D & 0.793 & 0.478 & 0.775 & 0.441 & 0.469 \\
\hline
\end{tabular}

\begin{tabular}{cccccc}
\hline & \multicolumn{5}{c}{$\mathrm{Ca}(\mathrm{II}): \mathrm{Fe}(\mathrm{III})$ molar ratio } \\
\cline { 2 - 6 } Method & $2: 1$ & $3: 1$ & $4: 1$ & $5: 1$ & $6: 1$ \\
\cline { 2 - 6 } & \multicolumn{5}{c}{ Interlayer distance, d/nm } \\
\hline A & 0.789 & 0.778 & 0.763 & 0.759 & 0.769 \\
B & 0.782 & 0.774 & 0.775 & 0.754 & 0.761 \\
C & 0.773 & 0.775 & 0.775 & 0.773 & 0.777 \\
D & 0.489 & 0.489 & 0.490 & 0.491 & 0.481 \\
\hline
\end{tabular}

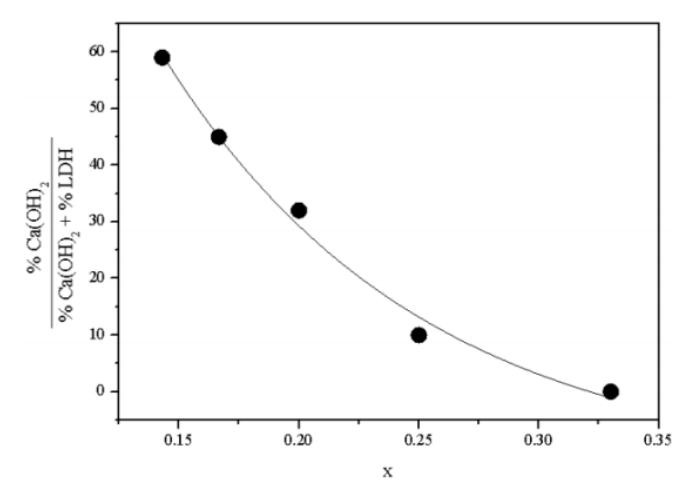

Figure 11. The relative quantity of the $\mathrm{Ca}(\mathrm{OH})_{2}$ phase in the function of the molar fraction $(x)$ of $\mathrm{Fe}(I I I)$ in the $\mathrm{Ca}_{n} \mathrm{Fe}-\mathrm{LDH}$ samples (where $n$ is the $\mathrm{Ca}(\mathrm{II}) / \mathrm{Fe}(\mathrm{III})$ ratio in the synthesis mixture). 
As it is seen, the $\mathrm{Ca}(\mathrm{OH})_{2}$ content almost linearly increased with increasing $\mathrm{Ca}(\mathrm{II}) / \mathrm{Fe}(\mathrm{III})$ ratio, i.e., as the relative $\mathrm{Ca}(\mathrm{II})$ content increased, substantially smaller amount of $\mathrm{Ca}$ was incorporated into the layers of the LDH compared to the intended composition. However, the basal spacing increased as the $\mathrm{Ca}$ (II) content increased, which may be taken as a sign of the increasing number of $\mathrm{Ca}(\mathrm{II})$ ions in the environment of $\mathrm{Fe}(\mathrm{III})$ ions.

Data reveal that $0.1 \mathrm{M}$ concentration for the $\mathrm{NaOH}$ solution is adequate for the successful synthesis of both hydrotalcite and hydrocalumite LDH types and using $\mathrm{N}_{2}$ blanket is advantageous if one does not want the strongly adhering $\mathrm{CO}_{3}{ }^{2-}$ ions to be present among the LDH layers. The evaluation of the diffractograms with the aid of the EXRAY program and comparing the results to ASTM standard data files reveals that the reflections of $\mathrm{Ca}(\mathrm{II})_{\mathrm{n}} \mathrm{Fe}(\mathrm{III})-\mathrm{LDH}$ s can be indexed for a hexagonal lattice with $\mathrm{R} 3 \mathrm{~m}$ rhombohedral symmetry (Hexagonal Scalenohedral class), which is commonly used for description of LDH structures; from thus the lattice parameters could be determined (Table 2).

Table 2. Lattice parameters of $C a_{n} F e-L D H s$.

\begin{tabular}{ccccc}
\hline $\begin{array}{c}\text { Sample } \\
\text { (from Method } B)\end{array}$ & $\mathrm{d}(003) / \mathrm{nm}$ & $\mathrm{a} / \mathrm{nm}$ & $\mathrm{c} / \mathrm{nm}$ & $\mathrm{D}$ (thickness) / nm \\
\hline $\mathrm{Ca}_{2} \mathrm{Fe}-\mathrm{LDH}$ & 0.782 & 0.583 & 2.302 & 35.37 \\
$\mathrm{Ca}_{3} \mathrm{Fe}-\mathrm{LDH}$ & 0.774 & 0.583 & 2.306 & 35.61 \\
$\mathrm{Ca}_{4} \mathrm{Fe}-\mathrm{LDH}$ & 0.775 & 0.586 & 2.329 & 36.66 \\
$\mathrm{Ca}_{5} \mathrm{Fe}-\mathrm{LDH}$ & 0.754 & 0.579 & 2.270 & 34.64 \\
$\mathrm{Ca}_{6} \mathrm{Fe}-\mathrm{LDH}$ & 0.761 & 0.581 & 2.277 & 34.36 \\
\hline
\end{tabular}

The average value of D was calculated from FWHM of peak (003) and (006) using the Scherrer equation:

$$
\mathrm{D}=\frac{\mathrm{B} \lambda}{\beta \cos \theta}
$$

(where $\mathrm{B}$ is the shape factor, $\lambda$ is the $\mathrm{X}$-ray wavelength, $\beta$ is the line broadening at half of the maximum intensity (FWHM) in radians, and $\theta$ is the Bragg angle). The observed lattice parameters $\left(a\right.$ and $c$ ) are similar to that reported elsewhere. ${ }^{120} \mathrm{Ca}_{n} \mathrm{Fe}-\mathrm{LDH}$ has lattice parameter a of $\sim 0.58 \mathrm{~nm}$ due to the seven-coordination structure of $\mathrm{Ca}(\mathrm{II}){ }^{121}$ The FWHM of (hk0) was determined to be higher in MgFe- than in CaFe-LDHs showing the better crystalinity of CaFe-LDHs.

${ }^{57} \mathrm{Fe}$ Mössbauer spectra recorded at $295 \mathrm{~K}$ and $78 \mathrm{~K}$ are displayed in Figure 12 and relevant data are summarised in Table 3 for $\mathrm{Mg}_{\mathrm{n}} \mathrm{Fe}-\mathrm{LDH}$ and in Figure 13 and Table 4 for 
$\mathrm{Ca}_{\mathrm{n}} \mathrm{Fe}-\mathrm{LDH}$. The evaluation of the Mössbauer spectra obtained at $295 \mathrm{~K}$ was optimal with fitting an asymmetric doublet. It should be pointed out at once that this asymmetry is probably not related to texture effects as one might think. The asymmetry may be attributed to $\mathrm{Fe}^{3+}$ positional disorder within the $\mathrm{Fe}(\mathrm{OH})_{6}$ octahedra. This is expected since the iron centres are surrounded by $\mathrm{Fe}^{3+}$ and $\mathrm{M}(\mathrm{II})$ at random, and these randomly distributed neighbouring octahedra exert perturbations on the $\mathrm{Fe}^{3+}$ centres with varying intensities. ${ }^{23}$

The ${ }^{57} \mathrm{Fe}$ Mössbauer parameters reflect high-spin Fe(III) microenvironments for all cases. ${ }^{57} \mathrm{Fe}$ Mössbauer measurements were repeated on a series of freshly prepared samples cooled immediately to $78 \mathrm{~K}$ after their preparation to avoid structural changes due to the possible reaction with aerial $\mathrm{CO}_{2}$. Spectra and parameters obtained were reproducible for every sample. At $295 \mathrm{~K}$ the Mössbauer parameters were in excellent correspondence with those measured at $78 \mathrm{~K}$, except the isomer shifts, which displayed some changes due to second order Doppler shift.

Table 3. ${ }^{57} \mathrm{Fe}$ Mössbauer parameters obtained at $78 \mathrm{~K}$ and $295 \mathrm{~K}$ for $\mathrm{Mg}_{\mathrm{n}} \mathrm{Fe}-\mathrm{LDHs}$.

\begin{tabular}{ccccccc}
\hline \multicolumn{5}{c}{$\operatorname{Mg}(\mathrm{II}): \mathrm{Fe}(\mathrm{III})$ molar ratio } \\
\cline { 3 - 7 } & & $2: 1$ & $3: 1$ & $4: 1$ & $5: 1$ & $6: 1$ \\
\hline \multirow{2}{*}{$78 \mathrm{~K}$} & $\Delta / \mathrm{mm} / \mathrm{s}$ & $0.46 \pm 0.004$ & $0.46 \pm 0.003$ & $0.46 \pm 0.005$ & $0.46 \pm 0.004$ & $0.46 \pm 0.005$ \\
& $\mathrm{~W} / \mathrm{mm} / \mathrm{s}$ & $0.53 \pm 0.01$ & $0.47 \pm 0.01$ & $0.46 \pm 0.01$ & $0.46 \pm 0.01$ & $0.48 \pm 0.015$ \\
\hline \multirow{2}{*}{$295 \mathrm{~K}$} & $\Delta / \mathrm{mm} / \mathrm{s}$ & $0.62 \pm 0.001$ & $0.54 \pm 0.003$ & $0.51 \pm 0.002$ & $0.51 \pm 0.003$ & $0.52 \pm 0.009$ \\
& $\delta / \mathrm{mm} / \mathrm{s}$ & $0.36 \pm 0.000$ & $0.37 \pm 0.003$ & $0.36 \pm 0.002$ & $0.37 \pm 0.002$ & $0.37 \pm 0.008$ \\
& $\mathrm{~W} / \mathrm{mm} / \mathrm{s}$ & $0.63 \pm 0.002$ & $0.76 \pm 0.007$ & $0.74 \pm 0.004$ & $0.68 \pm 0.005$ & $0.65 \pm 0.017$ \\
\hline
\end{tabular}

No change was observed in the isomer shift with the variation of $\mathrm{Mg}(\mathrm{II}) / \mathrm{Fe}(\mathrm{III})$ ratio, reflecting no change in the electronic density at the site of the iron nucleus in these LDHs. This is in agreement with the ionic character of these compounds. However, it has been found that the quadrupole splitting significantly decreased with increasing $\mathrm{Mg} / \mathrm{Fe}$ ratio indicating that the electric field gradient at the iron site increased on increasing iron content. This is consistent with the variations in the spatial charge distribution around the iron. At low iron content, in $\mathrm{Mg}_{6} \mathrm{Fe}-\mathrm{LDH}$, iron is situated in a layer where there are mainly $\mathrm{Mg}(\mathrm{II})$ ions in its second coordination sphere, which can supply a more symmetric charge distribution, consequently, a smaller electric field gradient and quadrupole splitting. In $\mathrm{Mg}_{2} \mathrm{Fe}-\mathrm{LDH}$, some 
$\mathrm{Mg}$ atoms in the second coordination sphere must be replaced by $\mathrm{Fe}(\mathrm{III})$ atoms increasing the electric field gradient and the quadrupole splitting. The results revealed that different microenvironments of iron were incorporated into $\mathrm{Mg}$ site in $\mathrm{Mg}_{\mathrm{n}} \mathrm{Fe}-\mathrm{LDH}$ structures at different $\mathrm{Mg}(\mathrm{II}) / \mathrm{Fe}(\mathrm{III})$ ratios.
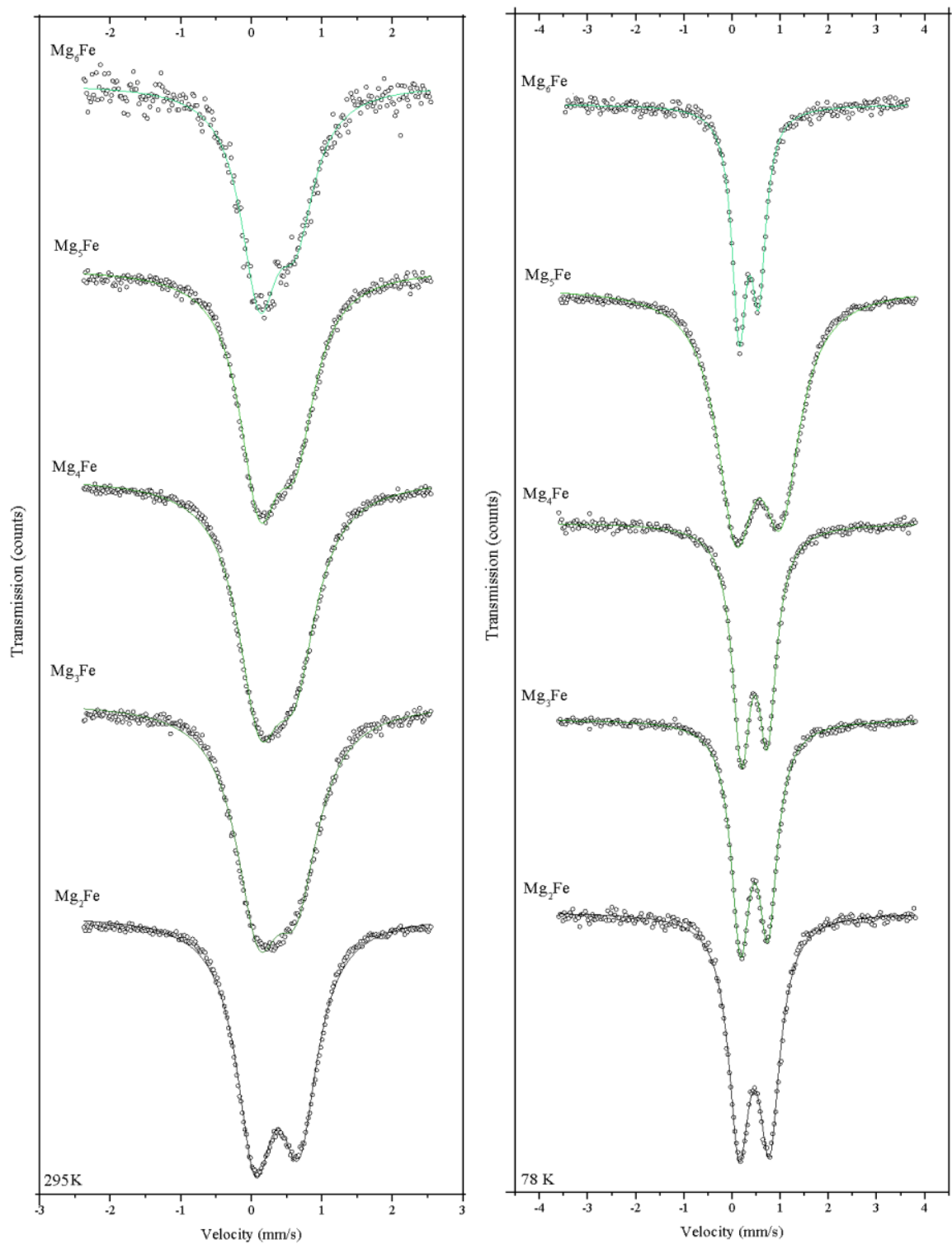

Figure 12. The ${ }^{57} \mathrm{Fe}$ Mössbauer spectra of $\mathrm{Mg}_{n} \mathrm{Fe}-\mathrm{LDH}$ at $78 \mathrm{~K}$ (left) and $295 \mathrm{~K}$ (right).

${ }^{57} \mathrm{Fe}$ Mössbauer measurements revealed significant differences only in the values of quadrupole splitting between $\mathrm{Ca}_{2} \mathrm{Fe}-\mathrm{LDH}$ and the other Ca-containing samples (Table 4). It may indicate a change in the charge distribution asymmetry between $\mathrm{Ca}_{2} \mathrm{Fe}-\mathrm{LDH}$ and the other samples, which is also the sign of the change in the amount of $\mathrm{Ca}(\mathrm{II})$ ions around the $\mathrm{Fe}(\mathrm{III})$ ions next to their immediate surroundings. The same isomer shift for all substances shows that the electron field density measured at the iron nucleus - which is characteristic of the chemical bond - was identical for every sample. 
Table 4. ${ }^{57} \mathrm{Fe}$ Mössbauer parameters obtained at $78 \mathrm{~K}$ and $295 \mathrm{~K}$.

\begin{tabular}{ccccccc}
\hline & & \multicolumn{5}{c}{$\mathrm{Ca}(\mathrm{II}): \mathrm{Fe}(\mathrm{III})$ molar ratio } \\
\cline { 3 - 7 } & & $2: 1$ & $3: 1$ & $4: 1$ & $5: 1$ & $6: 1$ \\
\hline \multirow{2}{*}{$78 \mathrm{~K}$} & $\Delta / \mathrm{mm} / \mathrm{s}$ & $0.46 \pm 0.001$ & $0.47 \pm 0.002$ & $0.47 \pm 0.001$ & $0.47 \pm 0.011$ & $0.47 \pm 0.003$ \\
& $\mathrm{~W} / \mathrm{mm} / \mathrm{s}$ & $0.49 \pm 0.003$ & $0.43 \pm 0.005$ & $0.41 \pm 0.003$ & $0.41 \pm 0.01$ & $0.39 \pm 0.008$ \\
\hline \multirow{2}{*}{$295 \mathrm{~K}$} & $\delta / \mathrm{mm} / \mathrm{s}$ & $0.37 \pm 0.003$ & $0.37 \pm 0.002$ & $0.37 \pm 0.003$ & $0.36 \pm 0.005$ & $0.37 \pm 0.003$ \\
& $\Delta / \mathrm{mm} / \mathrm{s}$ & $0.49 \pm 0.004$ & $0.41 \pm 0.002$ & $0.41 \pm 0.004$ & $0.40 \pm 0.005$ & $0.40 \pm 0.004$ \\
& $\mathrm{~W} / \mathrm{mm} / \mathrm{s}$ & $0.60 \pm 0.007$ & $0.54 \pm 0.004$ & $0.61 \pm 0.007$ & $0.64 \pm 0.010$ & $0.56 \pm 0.007$ \\
\hline
\end{tabular}
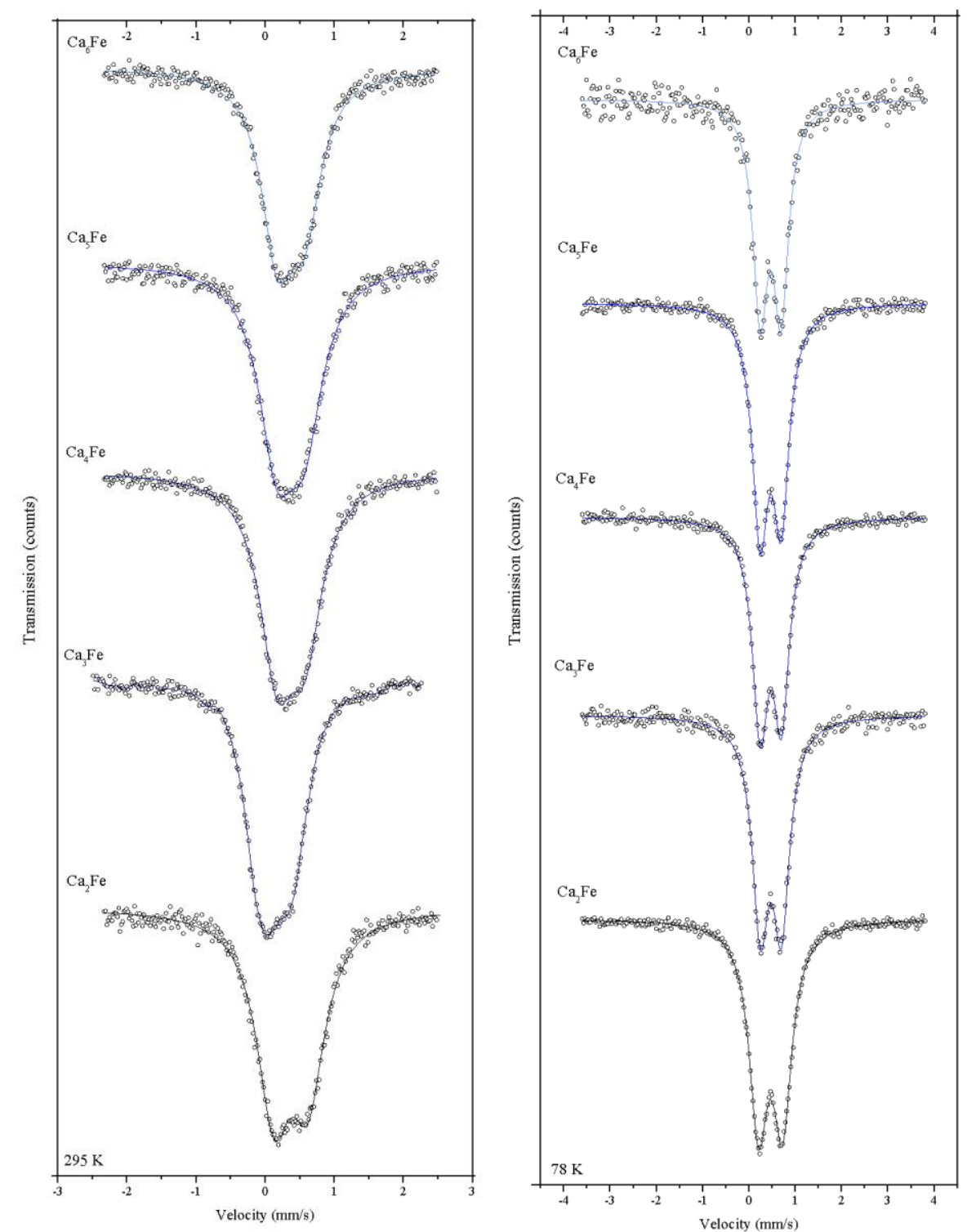

Figure 13. The ${ }^{57} \mathrm{Fe}$ Mössbauer spectra of $\mathrm{Ca}_{n} \mathrm{Fe}-\mathrm{LDH}$ at $78 \mathrm{~K}$ (left) and $295 \mathrm{~K}$ (right). 
It has been observed that letting the $\mathrm{Ca}_{2} \mathrm{Fe}-\mathrm{LDH}$ stand in air for an extended period of time ( $\sim 3$ months), the quadrupole splitting has changed from $0.49 \mathrm{~mm} / \mathrm{s}$ to $0.69 \mathrm{~mm} / \mathrm{s}$ at 298 K. Since the Mössbauer parameters of a freshly prepared sample were the same as of the original one before ageing, and those of the other samples did not vary with ageing, it can be stated that phase-pure $\mathrm{Ca}_{2} \mathrm{Fe}-\mathrm{LDH}$ decomposed on ageing and $\mathrm{CaCO}_{3}$ became the predominant crystalline phase. This is verified with the X-ray diffractogram of the aged sample (Figure 14).

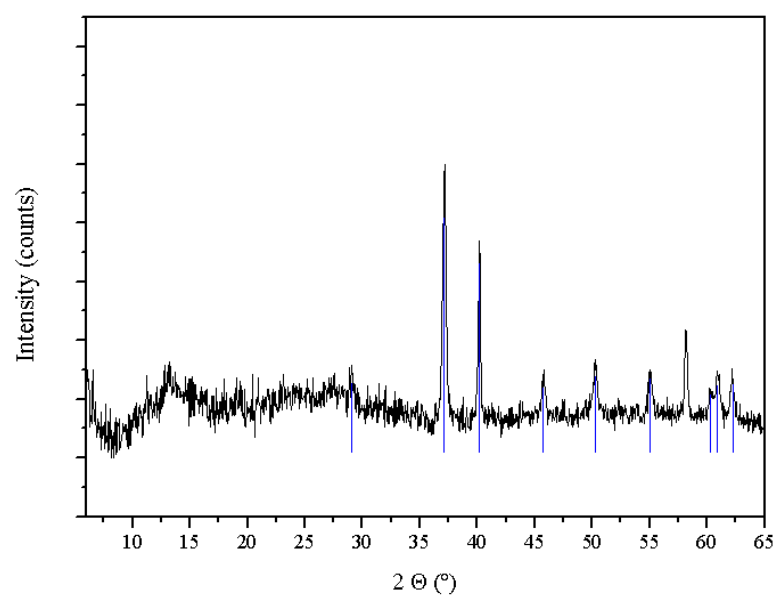

Figure 14. The X-ray diffractogram of $\mathrm{Ca}_{2} \mathrm{Fe}-\mathrm{LDH}$ after ageing in air for $\sim 3$ months $-\mathrm{CaCO}_{3}$ is the predominant crystalline phase (reflections denoted by vertical lines).

It seems to be clear that the presence of $\mathrm{Ca}(\mathrm{OH})_{2}$, even in small amount, inhibits the decomposition of the LDH phase, and therefore, exerts a stabilising effect. Although the $\mathrm{M}(\mathrm{II}): \mathrm{M}(\mathrm{III})$ ratio is 2 in hydrocalumites $-\mathrm{M}(\mathrm{OH})_{2}$ is also formed in all other compositions -, this ideal compositions of CaFe-LDH suffers from some instability. The 3:1 composition is proved to be ideal for further works of longer duration, since it is stable in air and contains $\mathrm{Ca}(\mathrm{OH})_{2}$ of only $\sim 10 \%$.

For more detailed investigations, described in the followings, the $\mathrm{Mg}_{4} \mathrm{Fe}-\mathrm{LDH}$ and the $\mathrm{Ca}_{3} \mathrm{Fe}-\mathrm{LDH}$ samples were chosen, since they nearly completely phase pure and they do not suffer such instability than lower $\mathrm{M}(\mathrm{II}) / \mathrm{Fe}$ (III) ratios. (In the sections where the intercalation work is described and discussed they will be mentioned as $\mathrm{CaFe}-$ and $\mathrm{MgFe}-\mathrm{LDHs}$.)

$\mathrm{X}$-ray absorption spectra of the pristine $\mathrm{Ca}_{3} \mathrm{Fe}-\mathrm{LDH}$ sample registered around the $\mathrm{Ca} 2 \mathrm{p}$, $\mathrm{Fe} 2 \mathrm{p}$ and $\mathrm{O} 1 \mathrm{~s}$ edges are seen in Figure 15. I am only going to give their qualitative description, and they will be used as references for those of the L-proline-CaFe-LDH sample. 


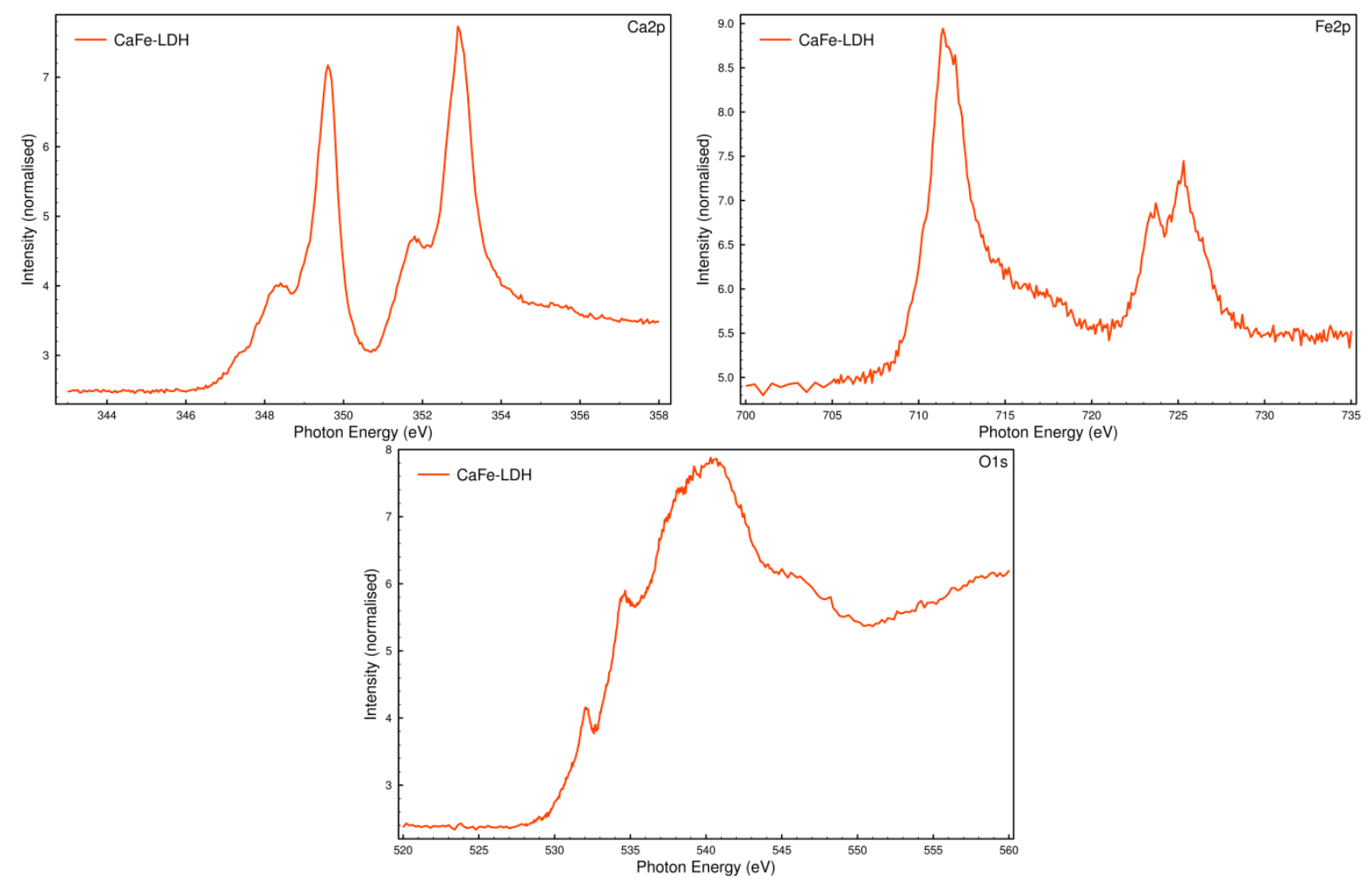

Figure 15. X-ray absorption spectra of the Ca $a_{3} F e-L D H$ sample performed around the Ca2p, Fe2p and Ols absorption edges.

Both the $\mathrm{Ca}$ and Fe X-ray absorption spectra contain two intense peaks, since the $2 \mathrm{p}$ and the $2 p_{1 / 2}$ energies are close to each other for both elements. The less intense peaks probably indicate separate phases and/or imperfections in the crystal structure. We know from XRD measurements that $\mathrm{Ca}(\mathrm{OH})_{2}$ is present as a minor but important stabilising component beside the LDH. Since there is no sign a separate Fe-containing non-LDH phase, the splitting in the peak at higher energy in the Fe X-ray absorption spectrum may be due to imperfections, probably vacancies in the LDH crystal structure. The O1s X-ray absorption spectrum has two pre-edge features indicating that oxygen is present in various environments. Beside the octahedral location in the $\mathrm{LDH}$ structure, the geometric environment in the $\mathrm{Ca}(\mathrm{OH})_{2}$ phase is probably different, just as at the imperfections of the LDH crystal lattice.

The results of thermal measurements are consistent with those characteristic of $\mathrm{MgFe}$ LDH compounds. ${ }^{23}$ The DTG curve for $\mathrm{Mg}_{\mathrm{n}} \mathrm{Fe}$ sample is shown in Figure 16. Two endothermic peaks located between 100 and $170{ }^{\circ} \mathrm{C}$ and at $320^{\circ} \mathrm{C}$ are observed. The first thermal event is attributed to the loss of physisorbed and interlamellar water (without the collapse of the layered structure) along with a grafting process of the interlamellar anion. The second thermal event (at $320^{\circ} \mathrm{C}$ ) is related to the collapse of the lamellar structure where both 
hydroxyl groups and interlamellar anions are released. The results are qualitatively consistent with those observed for other hydrotalcite systems. ${ }^{122}$

As for the $\mathrm{Ca}_{3} \mathrm{Fe}-\mathrm{LDH}$, until the collapse of the layered structure, water loss occurred in three major steps: first, desorption of physisorbed water $\left(100-150{ }^{\circ} \mathrm{C}\right)$, then removal of interlayer water $\left(175-350{ }^{\circ} \mathrm{C}\right)$ and finally, the loss of structural water $\left(400-475^{\circ} \mathrm{C}-\right.$ it is in the form of structural $\mathrm{OH}$ groups) leading to the deterioration of the layered structure. The temperature ranges differed for the two compounds.
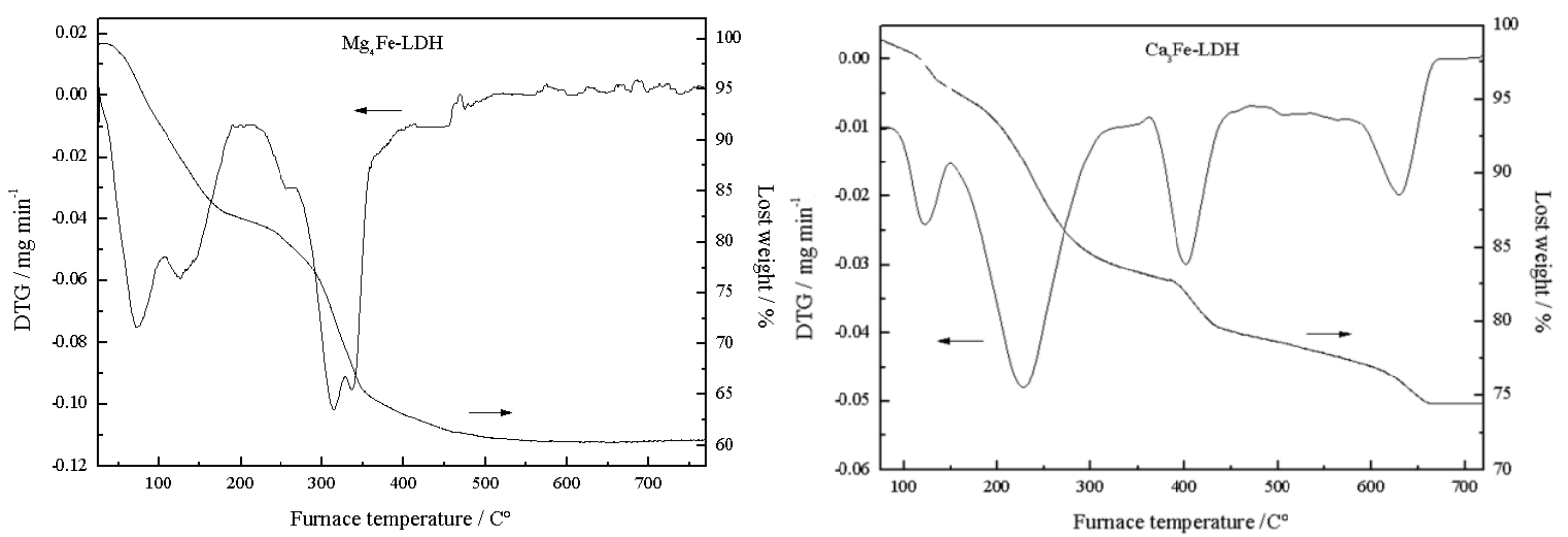

Figure 16. TG/DTG curves for $\mathrm{Mg}_{4} \mathrm{Fe}$ and $\mathrm{Ca}_{3} \mathrm{Fe} \mathrm{LDHs}$.

The FT-IR spectra (Figure 17) indicate the presence of isolated $\left(\mathrm{Ca}(\mathrm{II})_{3} \mathrm{Fe}(\mathrm{III})-\mathrm{LDH}\right.$ : $3640 \mathrm{~cm}^{-1}, \mathrm{Mg}(\mathrm{III})_{4} \mathrm{Fe}(\mathrm{III})-\mathrm{LDH}: 3731 \mathrm{~cm}^{-1}$ ) as well as hydrogen-bonded $\mathrm{OH}^{-}$groups in both samples (the broad bands above $3000 \mathrm{~cm}^{-1}$ ). This hydrogen-bonded network is among $\mathrm{OH}^{-}$ groups and water molecules adsorbed on the outer surface as well as present in the interlayer spacing. This band is much broader for $\mathrm{Mg}(\mathrm{II})_{4} \mathrm{Fe}(\mathrm{III})-\mathrm{LDH}$, indicating more extended hydrogen-bonded network.

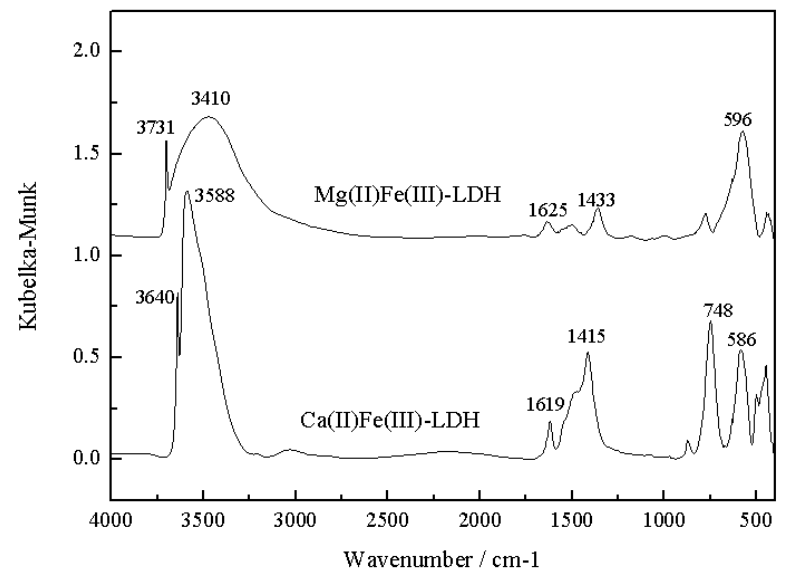

Figure 17. FTIR spectra of the $\mathrm{Ca}_{3} \mathrm{Fe}$ - and the $\mathrm{Mg}_{4} \mathrm{Fe}-\mathrm{LDH}$. 
Bands near $1620 \mathrm{~cm}^{-1}\left(\mathrm{Mg}_{4} \mathrm{Fe}-\mathrm{LDH}: 1625 \mathrm{~cm}^{-1}, \mathrm{Ca}_{3} \mathrm{Fe}-\mathrm{LDH}: 1619 \mathrm{~cm}^{-1}\right)$ are due to the deformation vibrations of the interlayer water molecules. Although not as widespread but equally important, FT-IR can describe the LDH lattice vibrations with an excellent degree of validity. Bands under $1000 \mathrm{~cm}^{-1}$ may be assigned to the $\mathrm{O}-$ metal ion- $\mathrm{O}$ units of the layers. These vibrations are dependent on the type of metals in the LDH, so different metals will lead to different vibrational mode ${ }^{123}$ assignments. Since chloride salts and $\mathrm{NaOH}$ were used in the synthesis, $\mathrm{Cl}^{-}$and $\mathrm{OH}^{-}$ions were the main interlayer anions. It should be noted that the band characteristic to the carbonate ion $\left(\sim 1360 \mathrm{~cm}^{-1}\right)$ is not seen in the spectra, therefore it is present in insignificant quantities among the layers.

SEM images also indicated the layered structure for both chosen samples (Figure 18 for $\mathrm{Mg}_{4} \mathrm{Fe}-\mathrm{LDH}$, Figure 19 for $\left.\mathrm{Ca}_{3} \mathrm{Fe}-\mathrm{LDH}\right)$. This is fortunate, since arrangement at the atomic level is not always reflected in the morphology of the materials. The basic shape of an LDH crystal is a hexagonal platelet. These large amounts of tiny crystals hardly grow out; instead they agglomerate in regions of less turbulence, resulting in a broad size distribution of agglomerated particles. In the agglomerated particles, the platelets are piled on top of each other. The di- and trivalent metal ions are largely evenly distributed in the samples, as it is seen in the SEM-EDX elemental maps.
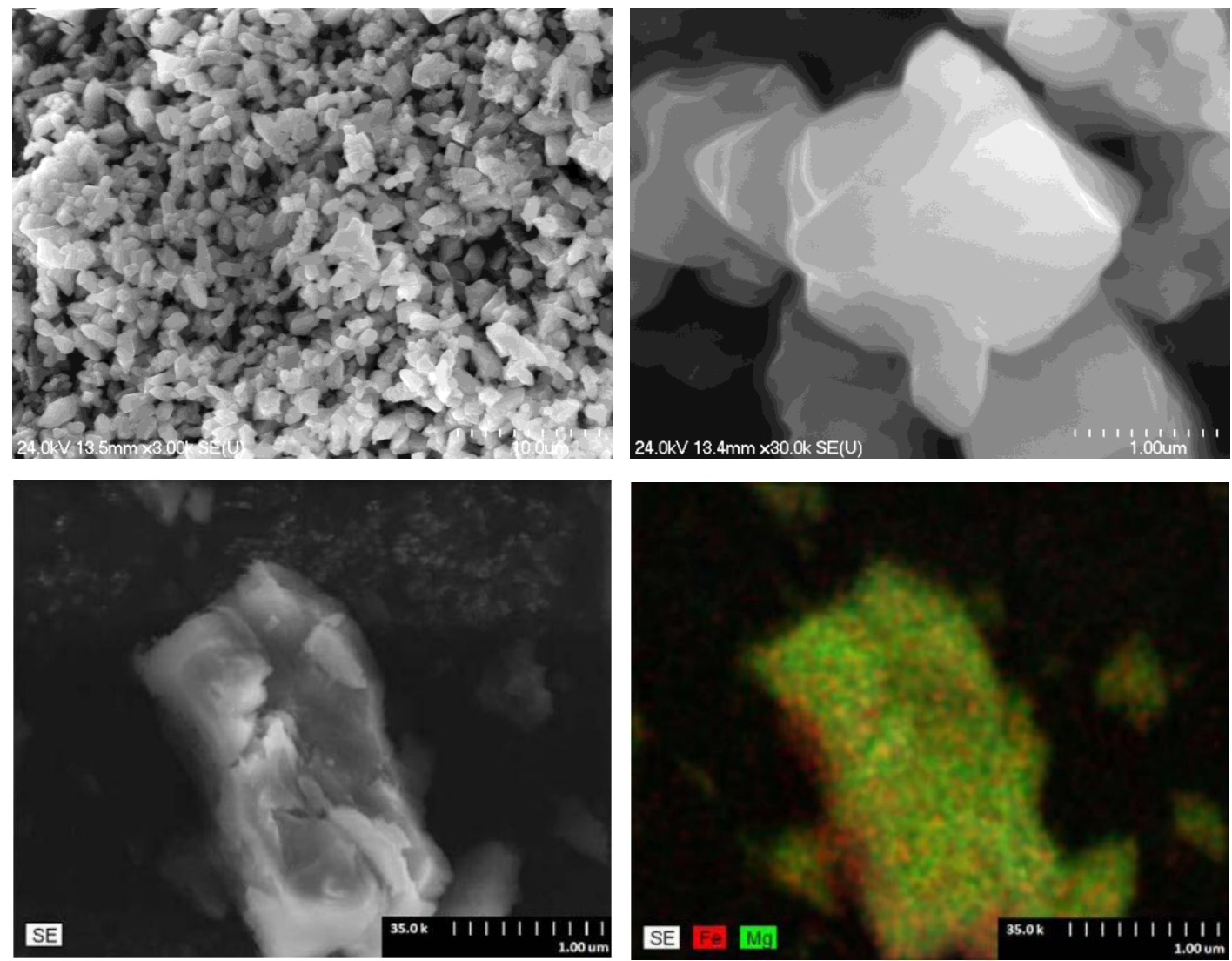

Figure 18. SEM images of $\mathrm{Mg}(\mathrm{II})_{4} \mathrm{Fe}(\mathrm{III})-\mathrm{LDH}$ at various magnifications and elemental map at magnification of 35,000 . 

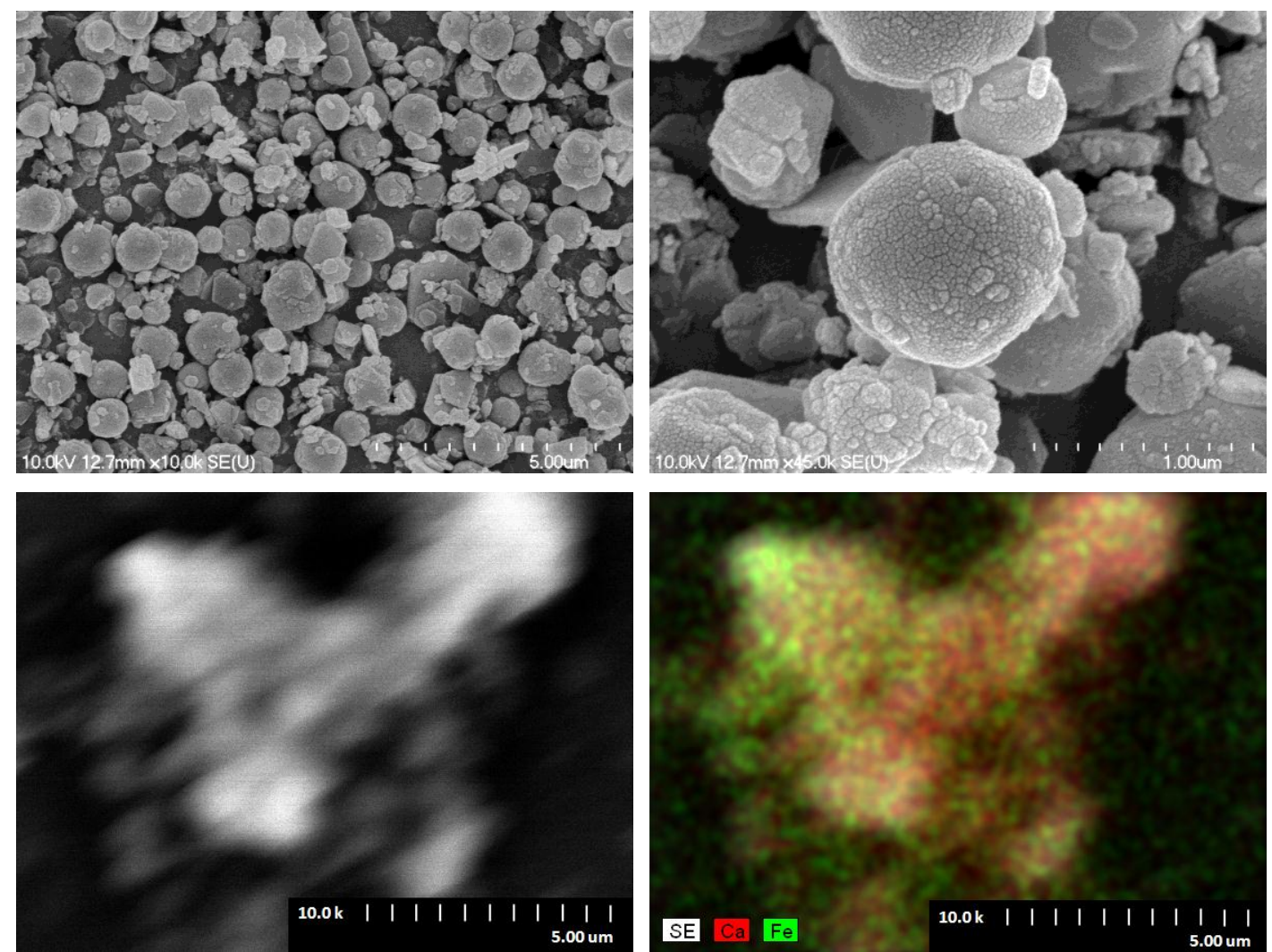

Figure 19. SEM images of $\mathrm{Ca}(\mathrm{II})_{3} \mathrm{Fe}(\mathrm{III})-\mathrm{LDH}$ at various magnifications and elemental map at magnification of 10,000 .

As stated earlier, $\mathrm{Ca}_{3} \mathrm{Fe}-\mathrm{LDH}$ has a rhombohedral crystal space group. When viewed by SEM, the LDH crystals appear as (hexagonally shaped) platelets, but the actual hexagonal shape is more clearly seen by the TEM image (Figure 20). The hexagonal platelets are the most common image for LDH with simple anions (halides, nitrate and carbonate), even if the LDH have a rhombohedral crystal polytype. This is not a contradiction, because the rhombohedral polytype refers to the layer stacking sequence and the hexagonal platelets refer to overall crystal growth. Note, that LDHs have been observed to have quite different morphologies with certain organic anions. ${ }^{124}$

As can be seen, the pristine $\mathrm{Ca}_{3} \mathrm{Fe}-\mathrm{LDH}$ particles are of typical plate-like shape with the lateral size of $150-300 \mathrm{~nm}$, but the sample had a relatively broad size distribution because of crystal aggregation. 


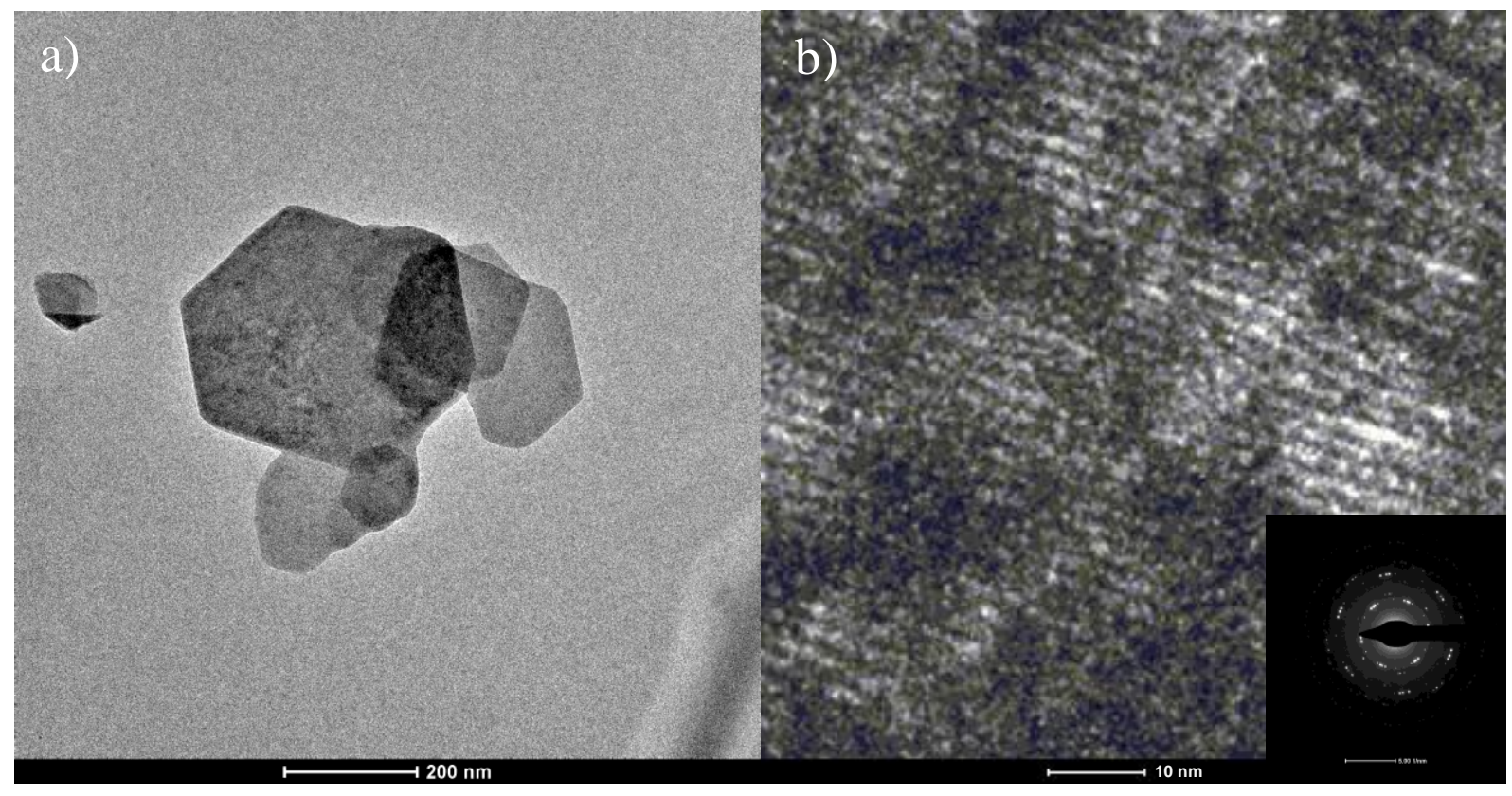

Figure 20. Bright field (a) and dark-field (b) TEM images of $\mathrm{Ca}_{3} \mathrm{Fe}-\mathrm{LDH}$.

The distance of two layers in the $\mathrm{Ca}_{3} \mathrm{Fe}-\mathrm{LDH}$ sample was estimated from a transmission electron microscopic (TEM) dark-field image (Figure 20. b), giving a value of approximately $0.58 \mathrm{~nm}$. If one substracts this from the basal spacing obtained from powder XRD, the layer thickness value $(0.19 \mathrm{~nm})$ is in good agreement with the $0.178 \mathrm{~nm}$, determined by others from high-precision XRD data. ${ }^{21}$ 


\subsection{Intercalation into the $\mathrm{Ca}_{3} \mathrm{Fe}-\mathrm{LDH}$}

It has been found that the ideal $\mathrm{LDH}$ to prepare intercalated organic-inorganic composites is the $\mathrm{Ca}_{3} \mathrm{Fe}-\mathrm{LDH}$ (denoted as $\mathrm{CaFe}-\mathrm{LDH}$ in the followings), which is not air sensitive, stable in aqueous solution, and has reasonably large primary particle size.

The carboxylate anions were intercalated into CaFe-LDH with the dehydrationrehydration method, utilising the memory effect of the layered double hydroxides.

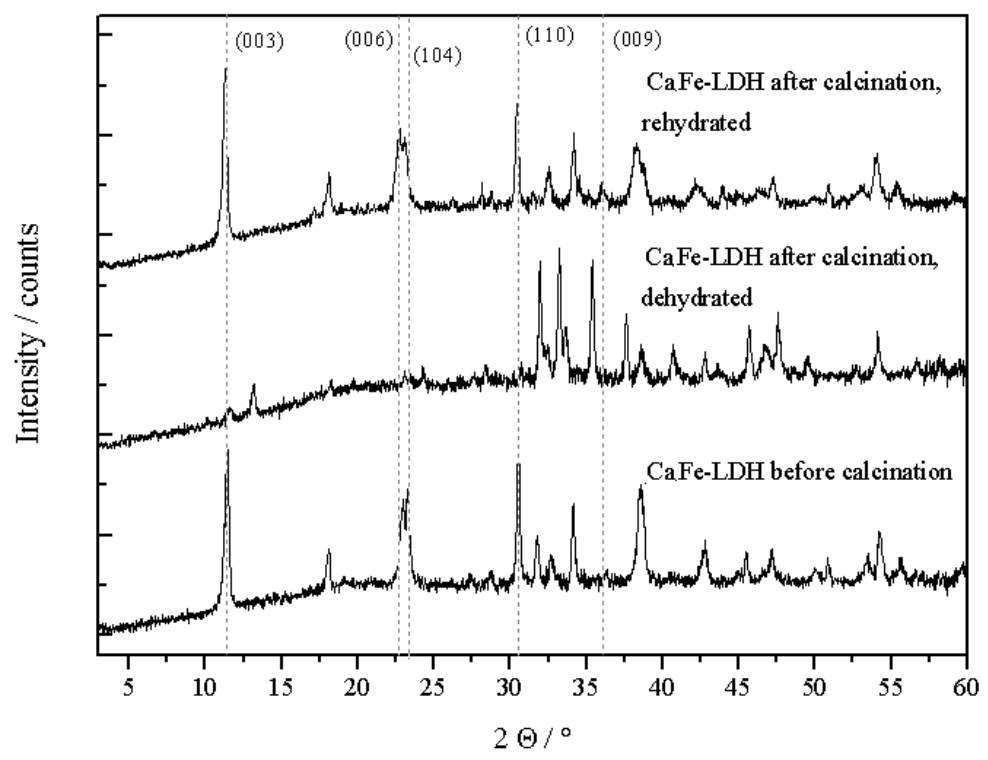

Figure 21. Dehydration (at $500{ }^{\circ} \mathrm{C}, \mathrm{N}_{2}$ ) and rehydration (in ethanol/water solution) of the CaFe-LDH.

First, it was verified that upon these conditions the rehydration of the "layered double oxide" occurred and the original structure restored indeed (Figure 21).

In the course of intercalation the heterocyclic compounds were suspended in alkaline ethanol/water or acetone/water solvent mixtures. Upon rehydration, ion exchange occurred as well. Powder XRD measurements were performed on the pristine LDH and the sodium salt of the carboxylic acids, as well as the intercalated samples obtained from both solvent mixtures. Carbon dioxide was carefully excluded from the reaction mixture, to avoid intercalation of carbonate ion in the positively charged layer, since in this case further ion exchange (i.e., substitution of the carbonate ion) would have been tremendously difficult.

Obviously, one has to make sure that the intercalation was successful, therefore characterisation steps followed to prove the presence of the organic anions between the layers of the LDH. Powder XRD measurements were performed first on the pristine as well as the intercalated samples. The diffractograms obtained (Figure 22) were typical of LDHs, but for ease of comparison and perspicuity, only the first reflection are presented $\left(2 \Theta=3-14^{\circ}\right)$. 

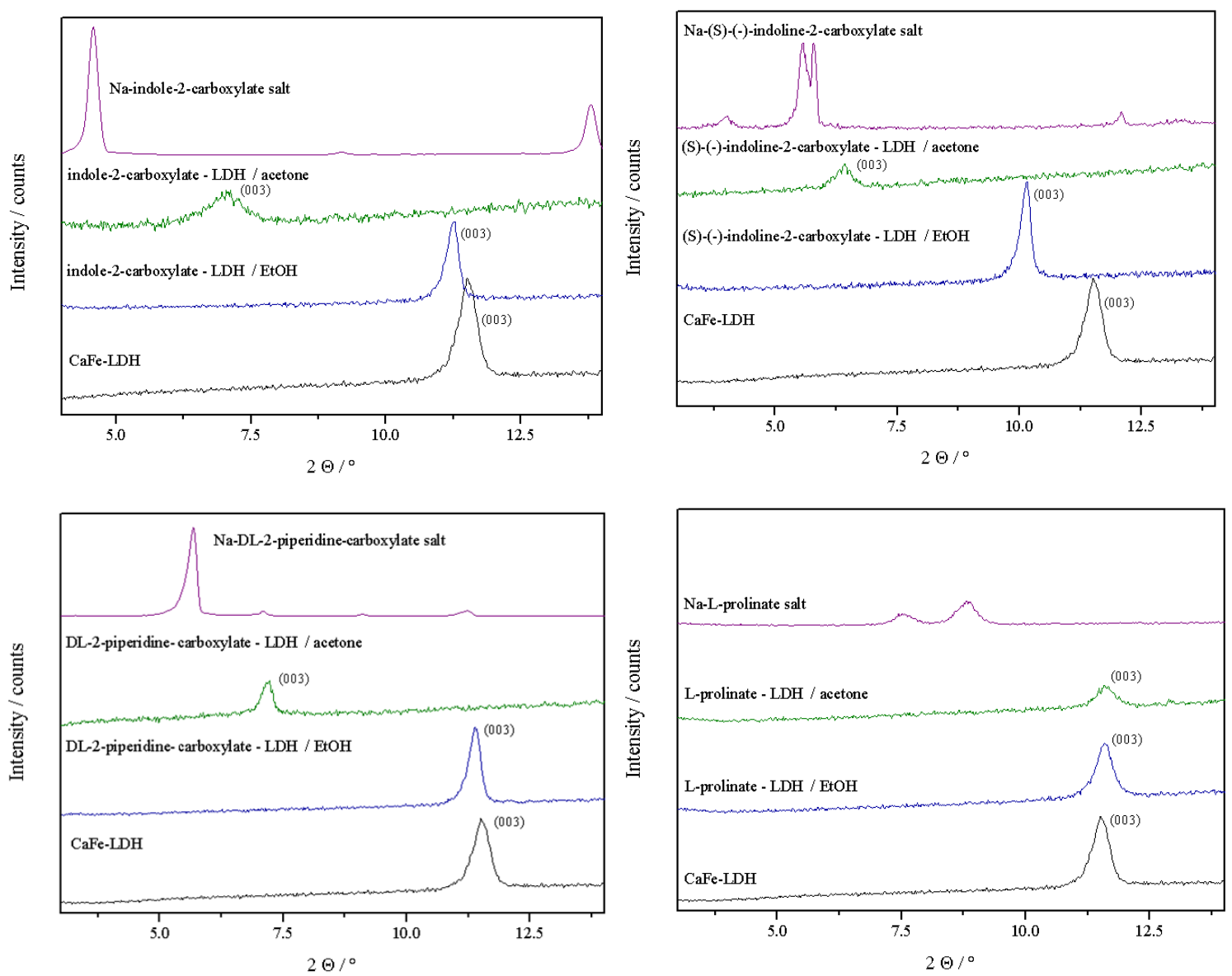

Figure 22. XRD traces of the pristine CaFe- $L D H$, the intercalated $L D H$ prepared from alkaline ethanol/water and acetone/water mixtures and the Na-salts of the carboxylate anions.

Basal spacings were calculated from the (003) reflection. The measured interlayer spacings contain one layer of the host material, which may be approximated as $0.178 \mathrm{~nm}$, according to Rousselot et al. ${ }^{21}$ Thus, the distance of the layers is shown in Table 5 along with the dimensions of the anions, optimised by the PM3 semiempirical code. Since the sizes of the $\mathrm{D}$ and $\mathrm{L}$ isomers are different, the dimensions of both were calculated. 


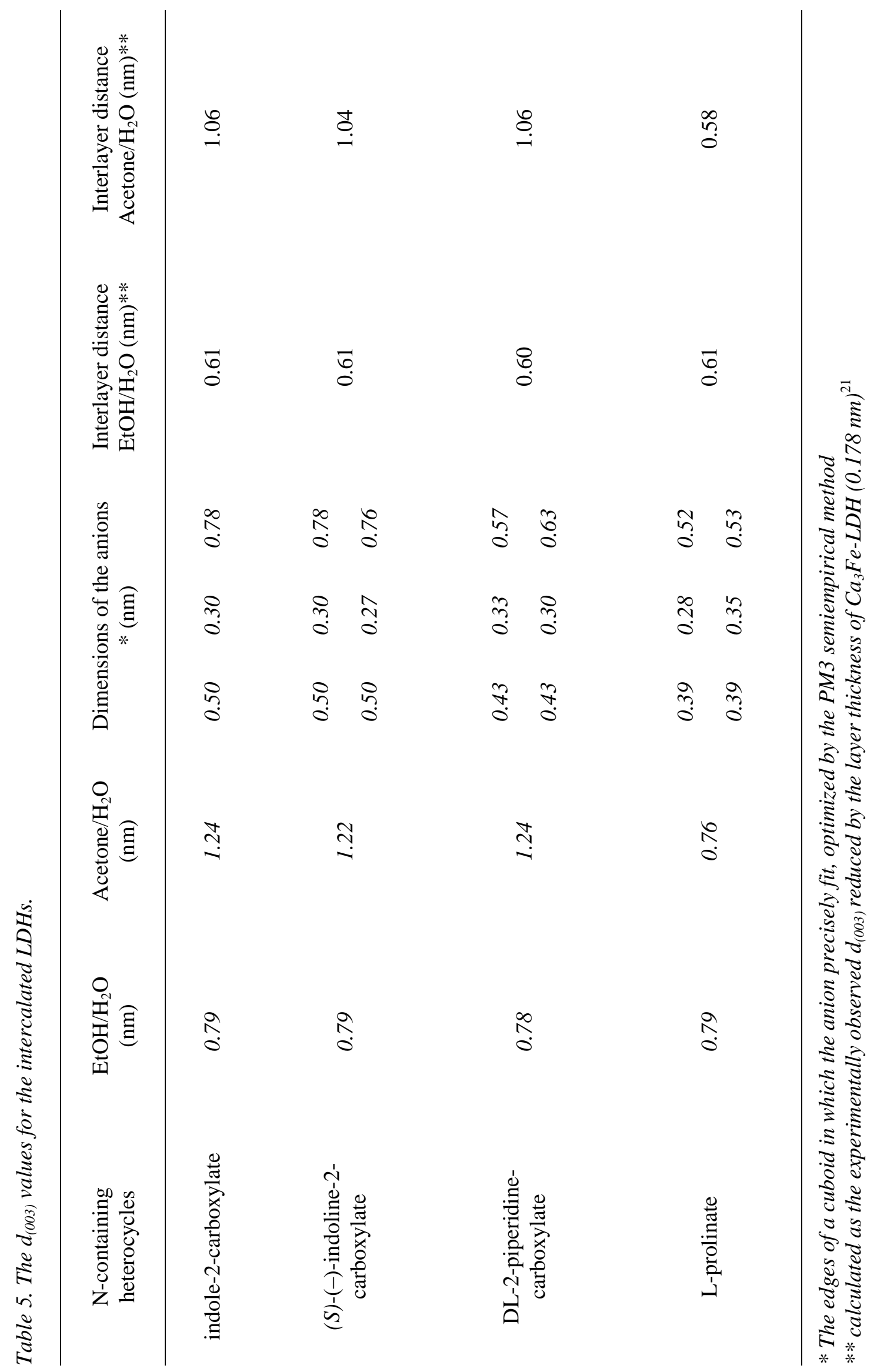


The interlayer distances were found to be significantly different in the intercalated LDHs prepared in different solvents. If the rehydration took place in alkaline acetone/water, XRD measurements indicated extremely increased interlayer distances in all cases except for the intercalated L-prolinate - sure sign of successful intercalation. In contrast if alkaline ethanol/water mixture was applied during syntheses the interlayer distances did not change significantly. Two possible explanations may account for these experimental results. Either there was no intercalation or the dimensions of the anions allow an arrangement in the gallery space of LDH that does not cause appreciable change in the basal distance. This issue and the possible arrangement of the organic molecules in the gallery space of LDHs will be discussed in the followings.

Determination of the amount of the intercalated indole-2-carboxylate between the layers was also attempted. Theoretically, the amount of the interlayer anions is equal to the $\mathrm{Fe}^{3+}-$ content of the layer. By ICP-OES measurements the iron-content of our pristine LDH was $6.859 \cdot 10^{-4} \mathrm{~mol} / \mathrm{g}$. This is the maximum quantity of the carboxylate anions that can be intercalated. UV-VIS spectroscopy was applied to find out the actual intercalated amount. Only the indole-2-carboxylic acid has appreciable absorbance in the range of 200-800 nm $(\lambda=218 \mathrm{~nm}$ and $292 \mathrm{~nm}$ ), therefore similar measurements could not be applied for the other intercalated ions.

Table 6. The indole-2-carboxylate content of the LDHs.

\begin{tabular}{lcc}
\hline & $\begin{array}{c}\text { indole-2-carboxylate-LDH } \\
\mathrm{EtOH} / \mathrm{H}_{2} \mathrm{O}\end{array}$ & $\begin{array}{c}\text { indole-2-carboxylate-LDH } \\
\text { acetone } / \mathrm{H}_{2} \mathrm{O}\end{array}$ \\
\hline $\begin{array}{l}\text { indole-2-carboxylate intercalated to } \\
\text { the } \mathrm{LDH}(\mathrm{mol} / \mathrm{g})\end{array}$ & $1.88 \cdot 10^{-4}-2.20 \cdot 10^{-4}$ & $2.38 \cdot 10^{-4}-2.75 \cdot 10^{-4}$ \\
$\left(\mathrm{n}_{\text {indole }} / \mathrm{n}_{\mathrm{Fe}}\right) \cdot 100$ & $27-32 \%$ & $34-40 \%$ \\
\hline
\end{tabular}

According to the UV-Vis measurements, the intercalation of indole-2-carboxylate in both in ethanol/water and in acetone/water was successful (Table 6), although slightly lower amount of organic anion was incorporated between the layers when aqueous ethanol was the solvent. A possible explanation can be that an aqueous medium favours the exchange with inorganic anions, whilst an organic solvent does it with organic anions. ${ }^{47}$

In order to confirm that the intercalation was successful, the samples were further studied by scanning electron microscopy followed by elemental mapping and EDX measurements. SEM micrographs of the samples were taken at various magnifications. 

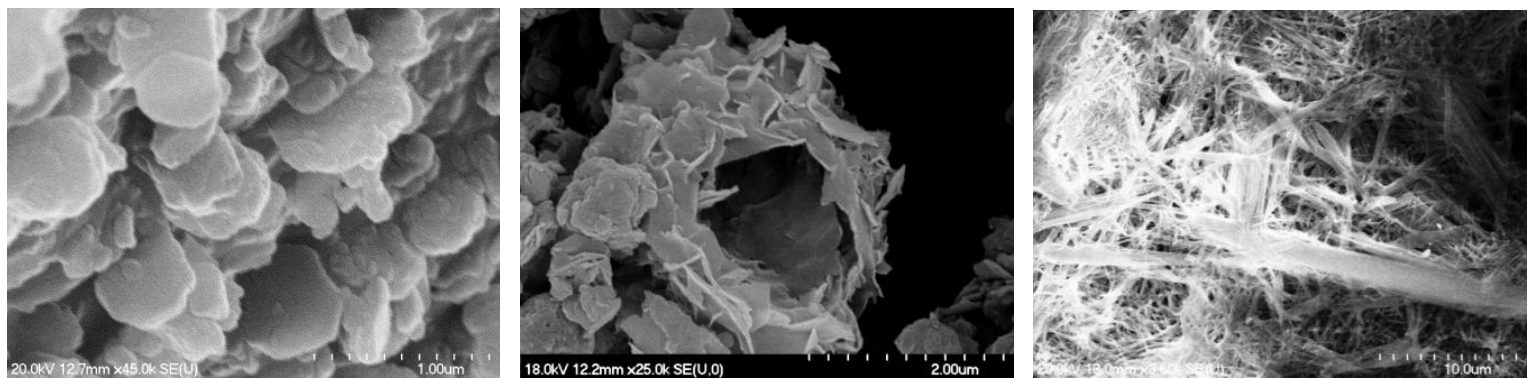

Figure 23. SEM images of (a) the indole-2-carboxylate- $\mathrm{LDH}$ prepared in $\mathrm{EtOH} / \mathrm{H}_{2} \mathrm{O}$, (b) the indole-2carboxylate-LDH prepared in acetone $\mathrm{H}_{2} \mathrm{O}$, (c) the sodium salt of the indole-2-carboxylic acid.
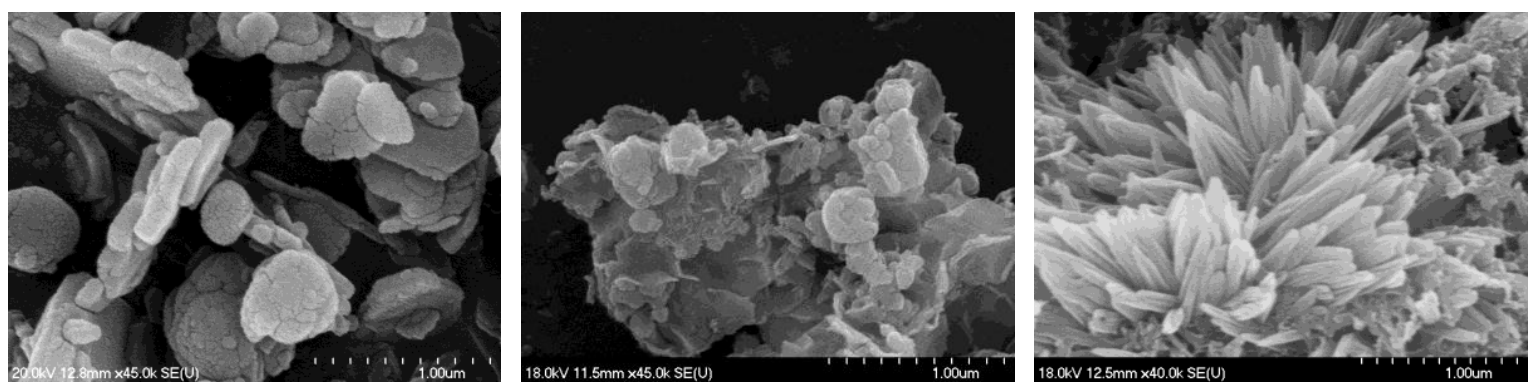

Figure 24. SEM images of (a) the (S)-(-)-indoline-2-carboxylate-LDH prepared in EtOH/H $\mathrm{H}_{2} \mathrm{O}$, (b) the (S)-(-)-indoline-2-carboxylate- $\mathrm{LDH}$ prepared in acetone $/ \mathrm{H}_{2} \mathrm{O}$, (c) the sodium salt of the (S)-(-)indoline-2-carboxylic acid.
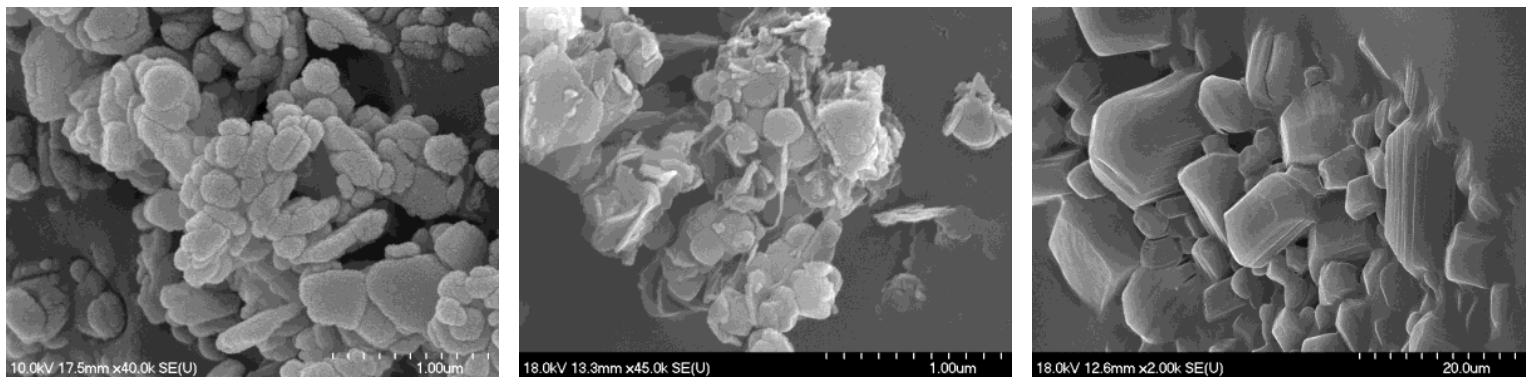

Figure 25. SEM images of (a) the DL-2-piperidine-carboxylate- $\mathrm{LDH}$ prepared in $\mathrm{EtOH} / \mathrm{H}_{2} \mathrm{O}$, (b) the $D L-2$-piperidine-carboxylate- $L D H$ prepared in acetone $/ \mathrm{H}_{2} \mathrm{O}$, (c) the sodium salt of the DL-2piperidine-carboxylic acid.
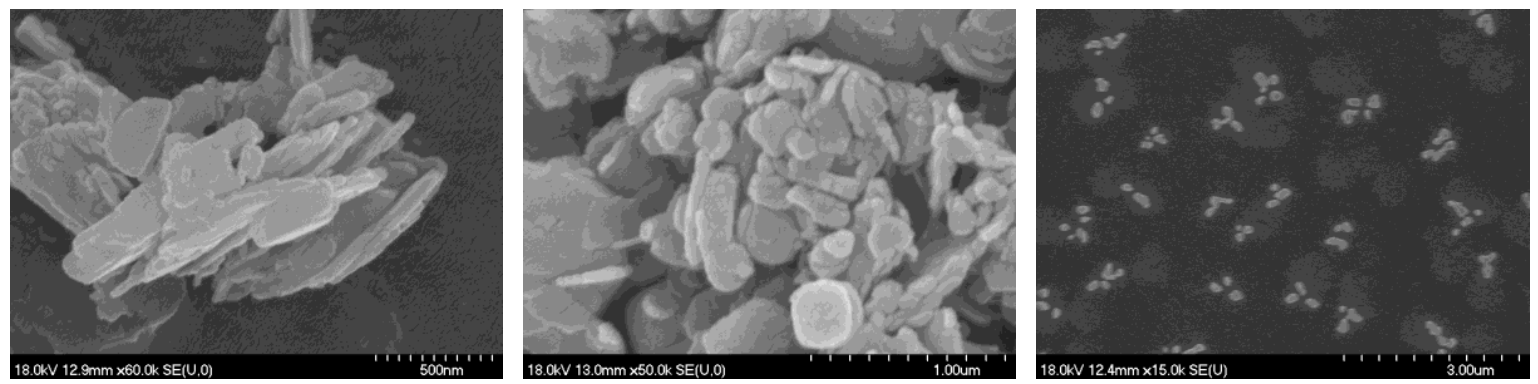

Figure 26. SEM images of (a) the L-prolinate- $\mathrm{LDH}$ prepared in $\mathrm{EtOH} / \mathrm{H}_{2} \mathrm{O}$, (b) the L-prolinate-LDH prepared in acetone $/ \mathrm{H}_{2} \mathrm{O},(\mathrm{c})$ the sodium salt of the L-proline.

The lamellar structures of the samples are clearly seen even at the lowest magnification. At the highest magnification one can see some minor differences in the morphologies of the 
samples obtained from the different solvents. The images reveal that the carboxylate ions are within the layers, since the significantly different crystals forms of the carboxylate salts are not seen on the outer surfaces of the lamellae of the hybrid materials even at relatively high magnifications.

The SEM-EDX combination allowed us to prepare the elemental map of the intercalated material. They are seen in Figure 27. a) - h) on the SEM images of the hybrids.

Figure 27.a-h) Elemental maps made on the SEM images of the samples.
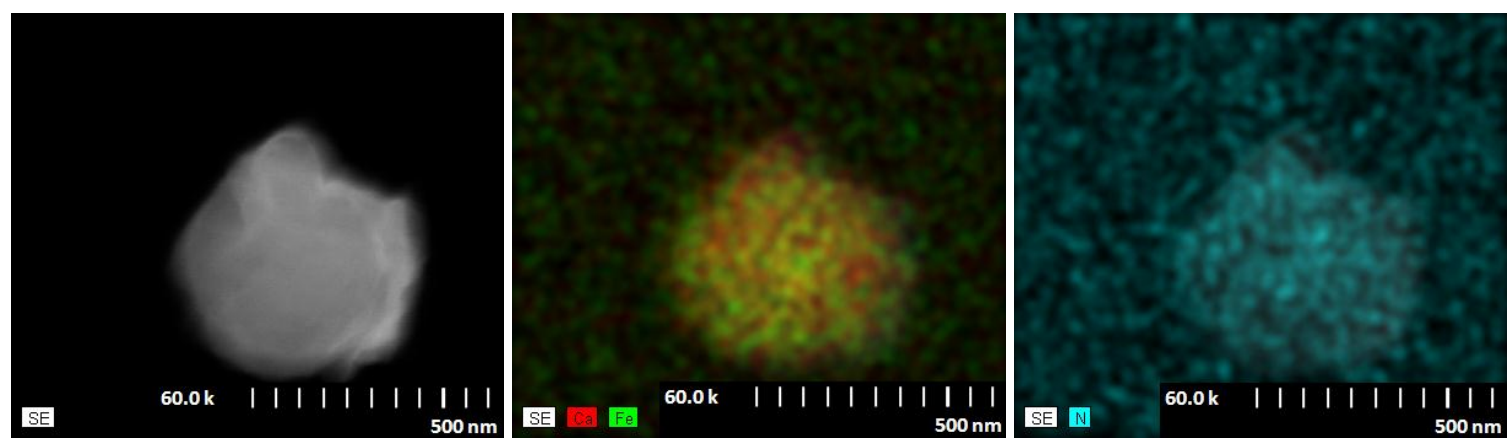

Figure 27.a) indole-2-carboxylate-LDH prepared in EtOH/ $\mathrm{H}_{2} \mathrm{O}$ (magnification at 60,000).
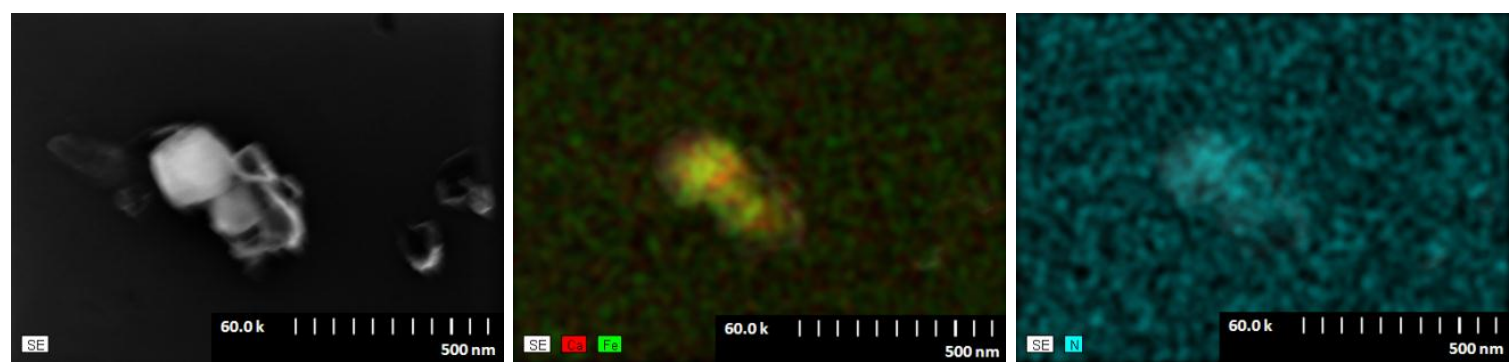

Figure 27.b) indole-2-carboxylate-LDH prepared in EtOH/ $\mathrm{H}_{2} \mathrm{O}$ (magnification at 60,000).
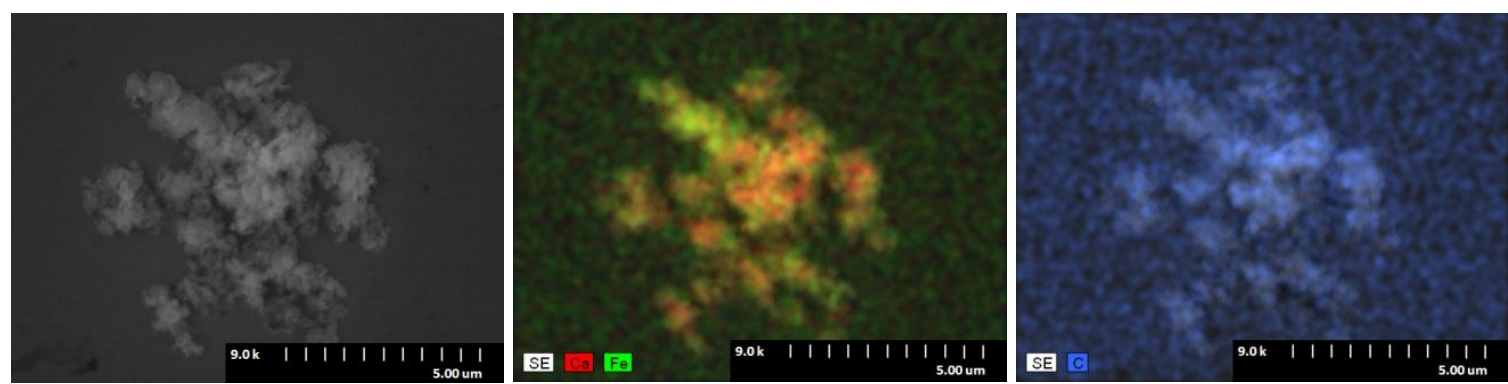

Figure 27.c) (S)-(-)-indoline-2-carboxylate-LDH prepared in EtOH/H $\mathrm{H}_{2} \mathrm{O}$ (magnification at 9,000). 


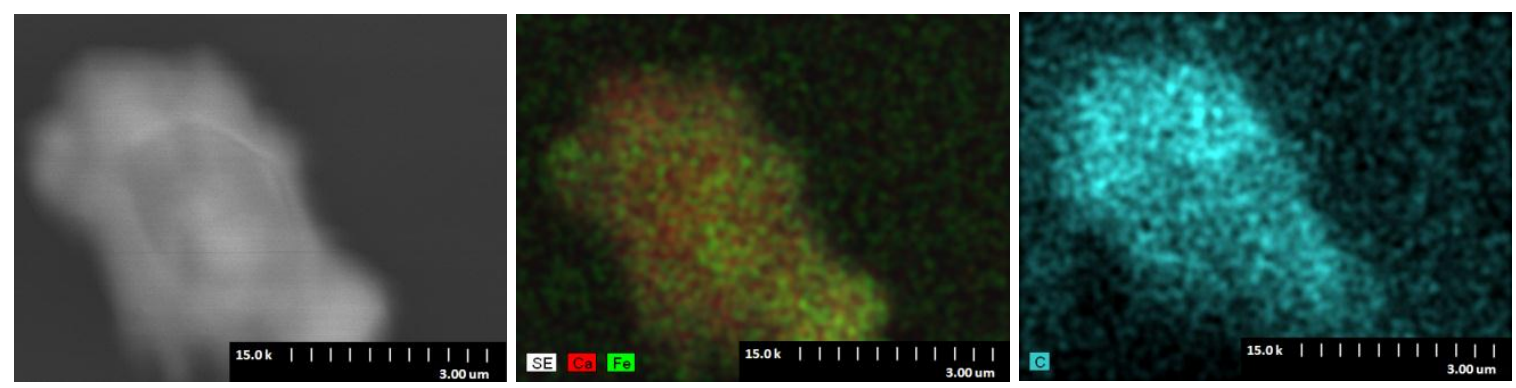

Figure 27.d) (S)-(-)-indoline-2-carboxylate-LDH prepared in acetone $/ \mathrm{H}_{2} \mathrm{O}$ (magnification at 15,000).
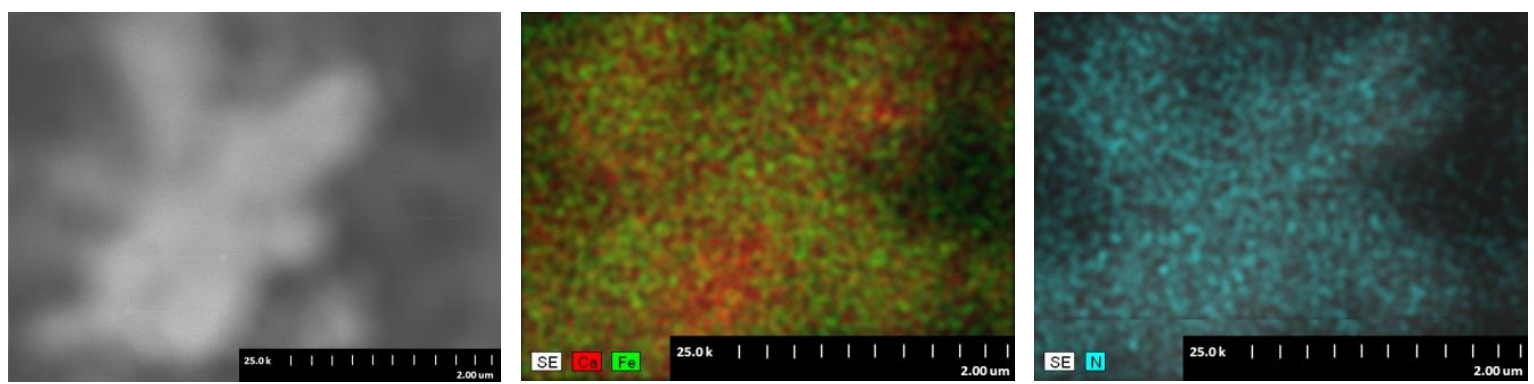

Figure 27.e) DL-2-piperidine-carboxylate-LDH prepared in $\mathrm{EtOH} / \mathrm{H}_{2} \mathrm{O}$ (magnification at 25,000).
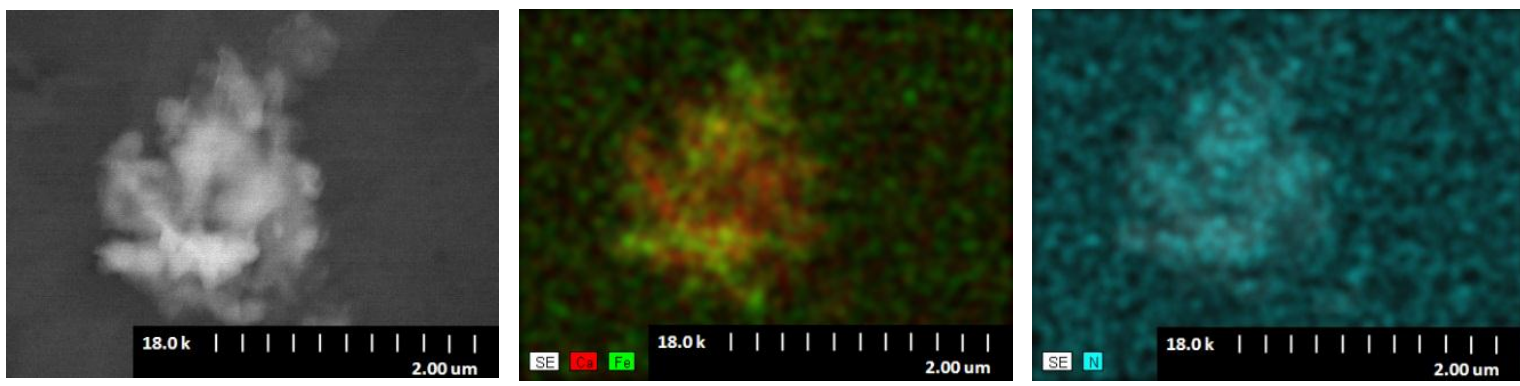

Figure 27.f) DL-2-piperidine-carboxylate-LDH prepared in acetone $/ \mathrm{H}_{2} \mathrm{O}$ (magnification at 18,000).
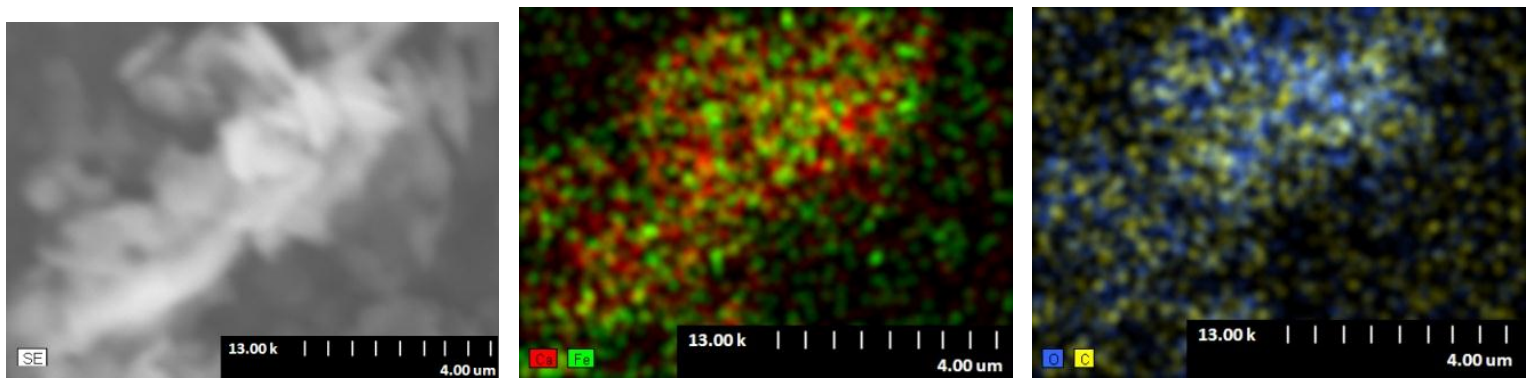

Figure 27.g) L-prolinate- $\mathrm{LDH}$ prepared in $\mathrm{EtOH} / \mathrm{H}_{2} \mathrm{O}$ (magnification at 13,000).
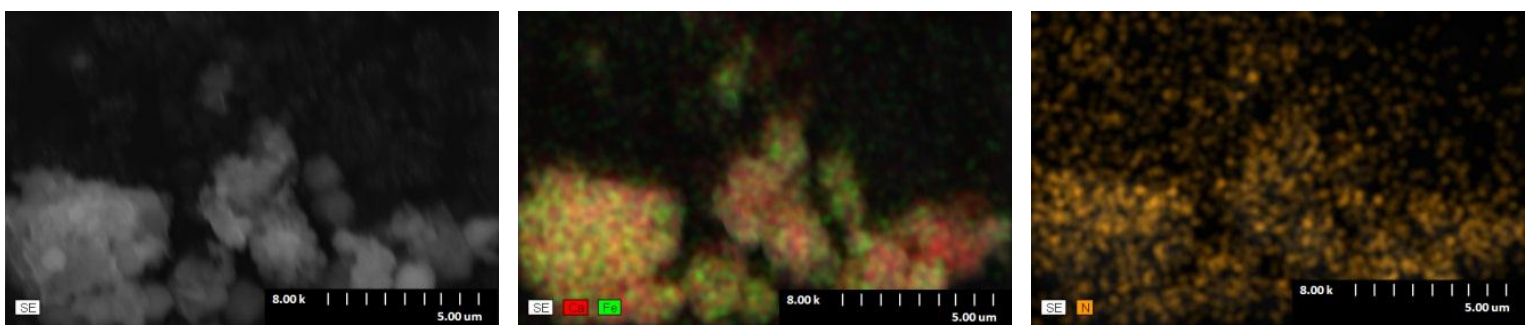

Figure 27.h) L-prolinate-LDH prepared in acetone $/ \mathrm{H}_{2} \mathrm{O}$ (magnification at 8,000). 
The $\mathrm{Ca}-\mathrm{Fe}$ maps verify that we have double hydroxides in our hands indeed, not only because the metals (ions) are evenly distributed in the sample, but also because there is no $\mathrm{Fe}$ or $\mathrm{Ca}$ accumulation, i.e. individual segregated oxides are not formed. The $\mathrm{C}-\mathrm{O}$, the $\mathrm{C}$ and the $\mathrm{N}$ maps indicate that the respective organic materials are also evenly distributed in the samples, i.e. the SEM images and this map - supplemented with the fact that we could not find any sign of $\mathrm{Na}$ which would refer to the presence of sodium salts - together convincingly show that the intercalation, and not adsorption on the outer surface of the LDH took place.

Thermal properties of the neat $\mathrm{LDH}$ and those of the intercalated samples were also compared and the major findings are shown on the example of the indole-2-carboxylateLDH. (Figure 28-Figure 29).
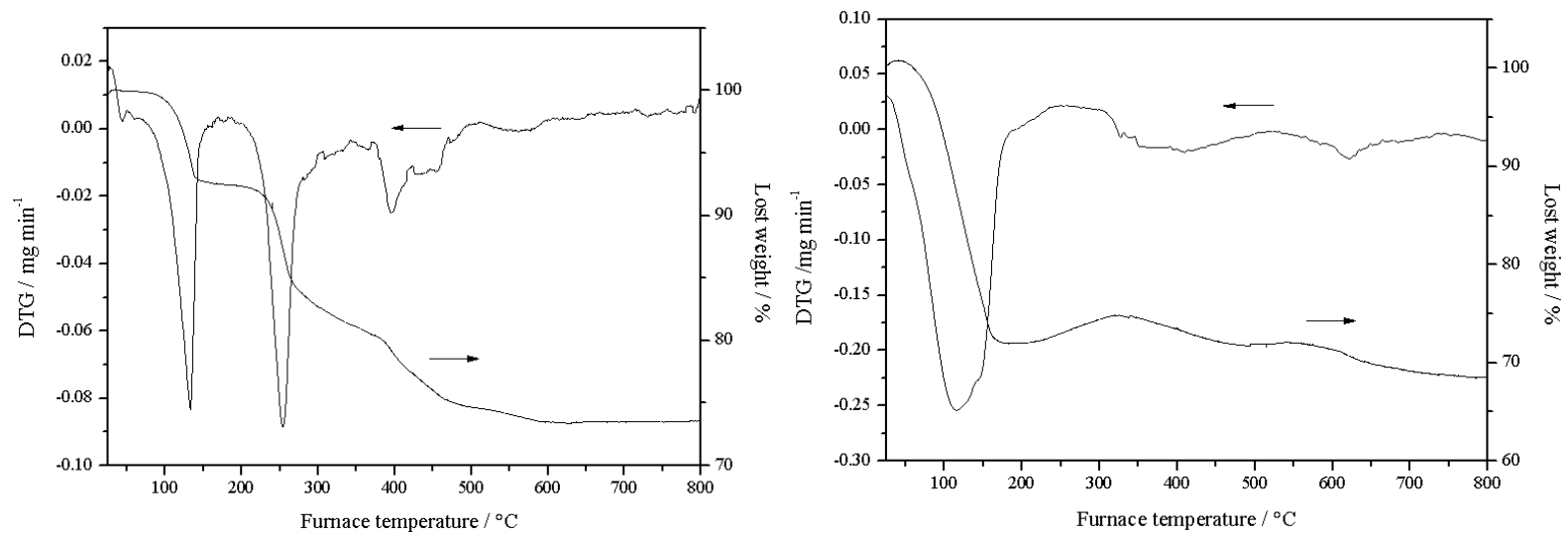

Figure 28. TG and DTG analysis of the original LDH and the indole-2-carboxylate-sodium salt.
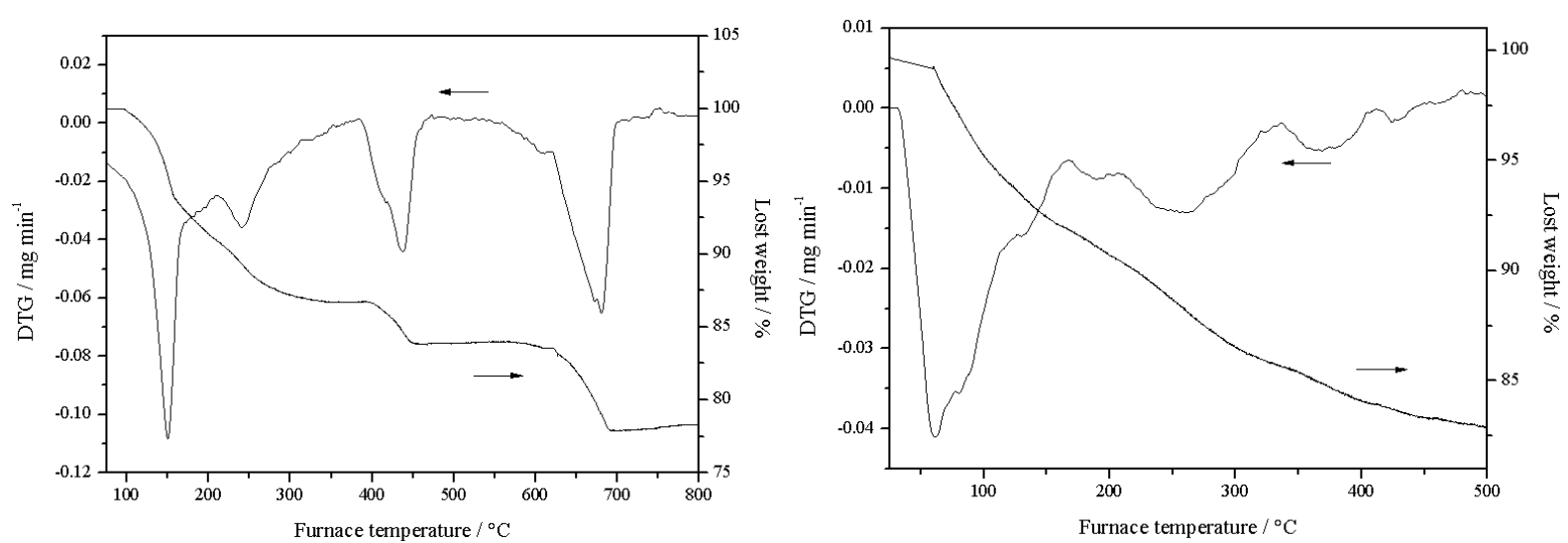

Figure 29. TG and DTG analysis of the indole-2-carboxylate- $\mathrm{LDH}$ prepared in $\mathrm{EtOH} / \mathrm{H}_{2} \mathrm{O}$ and the indole-2-carboxylate-LDH prepared in acetone $/ \mathrm{H}_{2} \mathrm{O}$.

The LDH without the organic compound displayed the expected behaviour typical of LDHs. First, the physisorbed water is desorbed in a relatively narrow temperature range (383-423 K), after that, the interlayer water is gradually removed in a wide temperature range (423-613 K), then the structural water leaves in a relatively narrow temperature range $(643-723 \mathrm{~K})$ and the layered structure collapses. The intercalated structure behaves 
differently in the sense that now we do not see the slowly leaving interlayer water. Instead, within 100 degrees $(623-723 \mathrm{~K})$ the organic material and possibly the structural water leave and the layered structure collapses. In both examined cases weight losses happened at slightly lower temperatures if acetone was used during synthesis.

The IR spectra of the samples (organic salts, and the intercalated $\mathrm{CaFe}-\mathrm{LDH}$ ) were also taken and compared. The main goals were to see if there were organic molecules in the sample on one hand and if the carboxylate anions remained intact on the other hand, i.e., no undesired chemical reactions (e.g. degradation) took place during preparation.

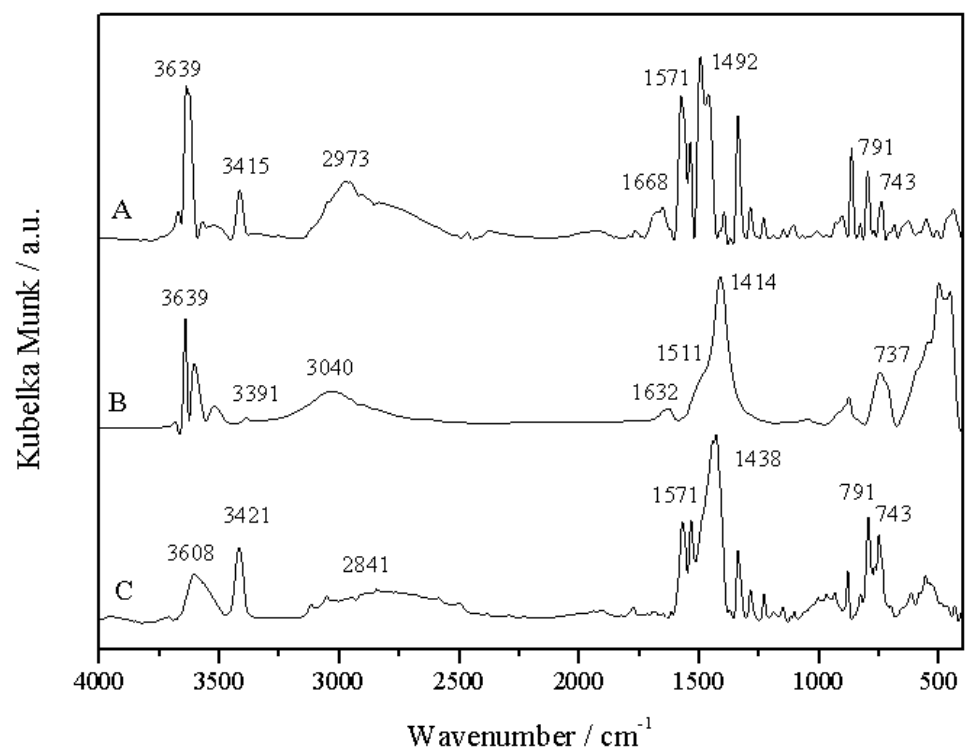

Figure 30. The difference IR spectra of the indole-2-carboxylate- $\mathrm{LDH}$ prepared in acetone $/ \mathrm{H}_{2} \mathrm{O}(\mathrm{A})$, the indole-2-carboxylate- $\mathrm{LDH}$ prepared in $\mathrm{EtOH} / \mathrm{H}_{2} \mathrm{O}(\mathrm{B})$ (the spectrum of the $\mathrm{LDH}$ was subtracted) and the Ir spectrum of the sodium salt of indol-2-carboxylate $(C)$.

The difference spectra and those of the corresponding spectra of the indole-2-carboxylate ions show close resemblance, therefore, it can be stated that the LDH samples contained the organic ions and they were intact. The band due to the $\mathrm{N}-\mathrm{H}$ stretching vibration $\left(3400-3250 \mathrm{~cm}^{-1}\right)$ is approximately equal in intensity in the spectra of the sodium salt and the organic-inorganic composite. However, for the intercalated anion, the peak shifted to higher energies and became less elongated demonstrating the success of intercalation. It can be seen in the vibrations of the carboxylate group $\left(\sim 1550 \mathrm{~cm}^{-1}\right)$ that the peaks are displaced and their intensities decrease also suggesting that the organic anion interacts with the layered double hydroxide. 


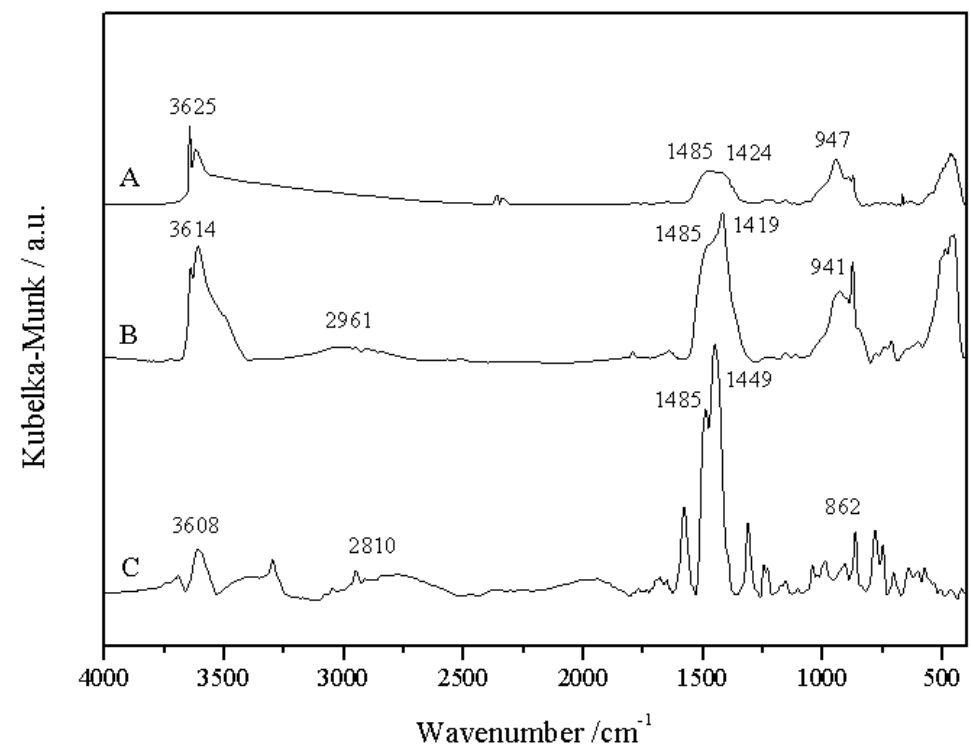

Figure 31. The difference IR spectra of the dihydroindole-2-carboxylate-LDH prepared in acetone $/ \mathrm{H}_{2} \mathrm{O}(\mathrm{A})$, the dihydroindole-2-carboxylate- $\mathrm{LDH}$ prepared in $\mathrm{EtOH} / \mathrm{H}_{2} \mathrm{O}(\mathrm{B})$ (the spectrum of the $\mathrm{LDH}$ was subtracted), and the sodium salt of dihydroindol-2-carboxylate $(C)$.
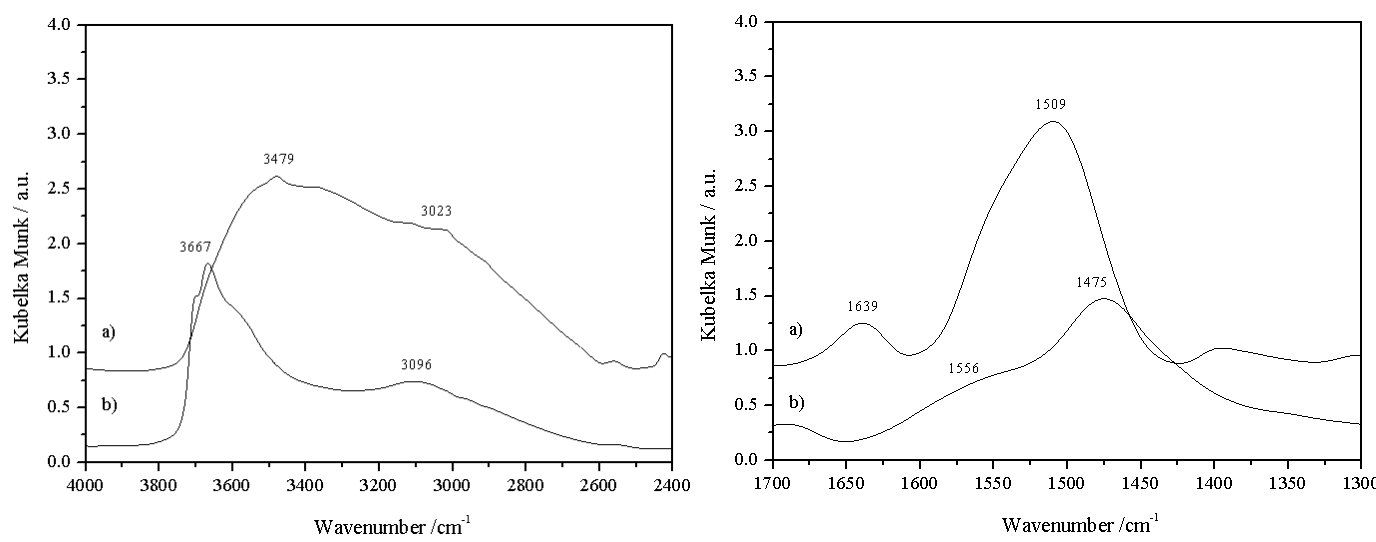

Figure 32. The IR spectra of the sodium salt of dihydroindol-2-carboxylate (a) and dihydroindole-2carboxylate- $\mathrm{LDH}$ prepared in acetone $/ \mathrm{H}_{2} \mathrm{O}(b)$ (the spectrum of the $\mathrm{LDH}$ was subtracted) focusing on the characteristics bands.

The same conclusions may be drawn regarding the composites containing dihydroindol-2-carboxylate: the amine band vibrations are approximately the same for the sodium salt and for the intercalated compound. The vibration bands around $3100-3000 \mathrm{~cm}^{-1}$ in all cases are probably due to the $-\mathrm{CH}$ group in the framework of the anion. In Figure 32, the characteristic band are enlarged: the vibrations due to the $\mathrm{N}-\mathrm{H}$ stretching and of the carboxylate group are depicted, thus one can clearly see the similarity. 


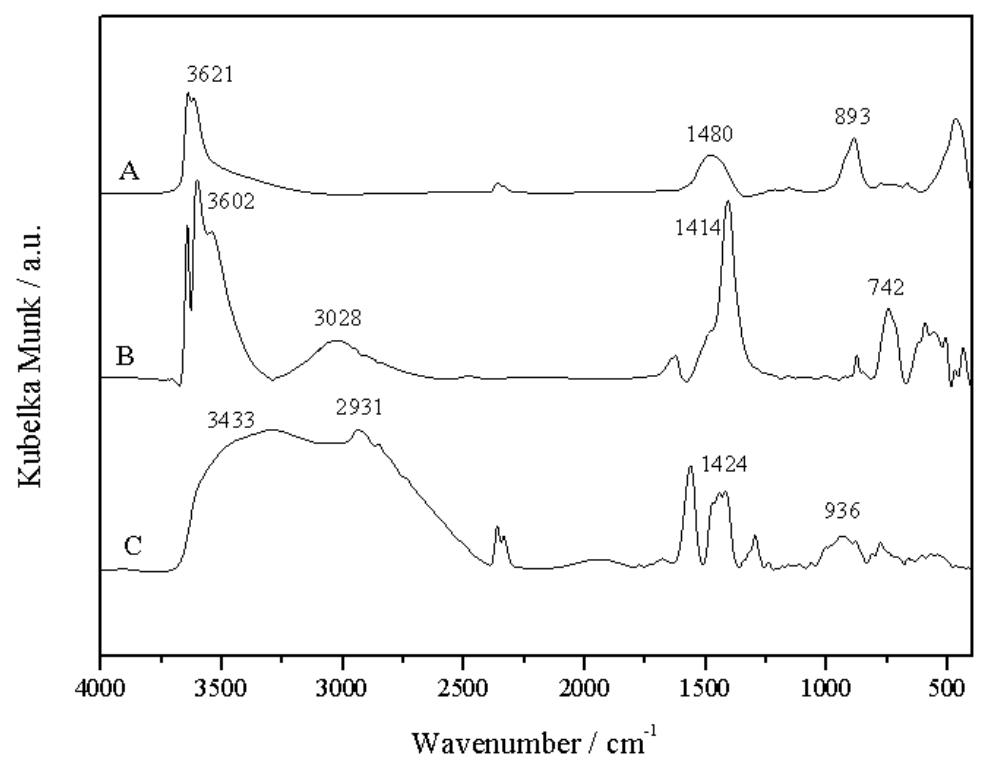

Figure 33. IR spectra of the DL-pipecolinate-LDH prepared in acetone $/ \mathrm{H}_{2} \mathrm{O}(\mathrm{A})$, the $D L$ pipecolinate-LDH prepared in $\mathrm{EtOH} / \mathrm{H}_{2} \mathrm{O}(B)$ and the sodium salt of DL-pipecolinate $(C)$.

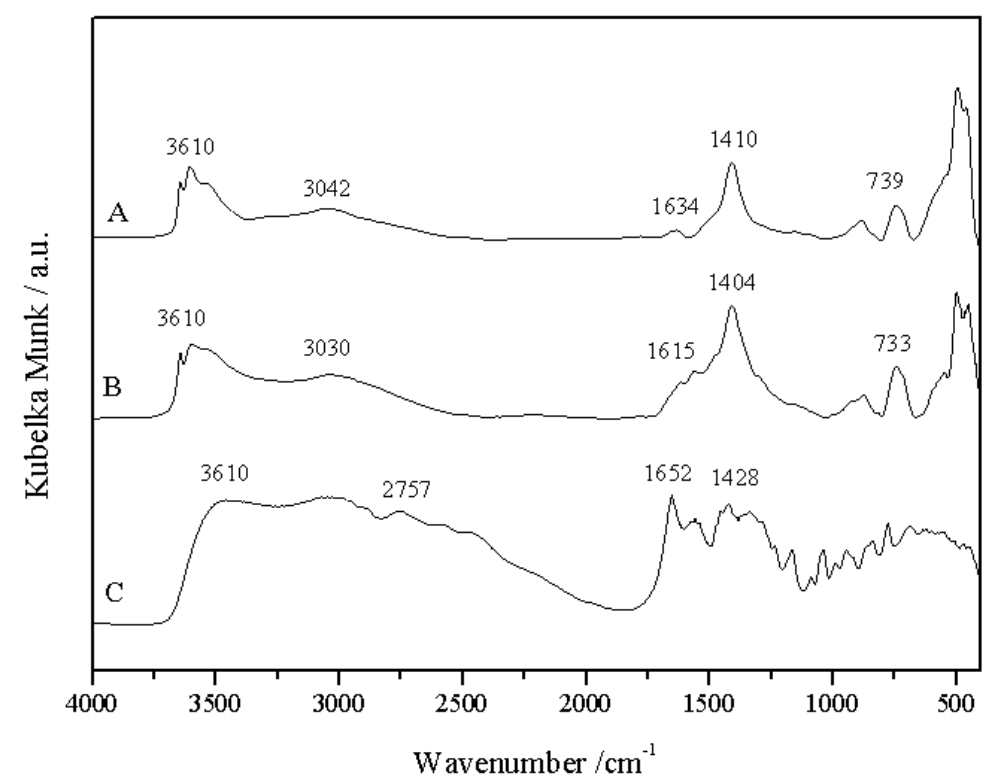

Figure 34. IR spectra of the L-prolinate- $\mathrm{LDH}$ prepared in acetone $/ \mathrm{H}_{2} \mathrm{O}(\mathrm{A})$, the L-prolinate- $\mathrm{LDH}$ prepared in $\mathrm{EtOH} / \mathrm{H}_{2} \mathrm{O}(B)$, and the sodium salt of L-prolinate $(C)$.

In Figure 34, the strong, wide bands at higher wavenumbers are most probably due to the amino groups. In the difference spectra of the intercalated LDH they are much sharper and less intense. There are significantly more absorption bands in the spectra of the pristine Lprolinate, compared to the intercalated anion. Nevertheless, the spectra of L-prolinate-LDH prepared in both solvents contain the peak around $1400 \mathrm{~cm}^{-1}$, which is presumably the vibration of the carbonyl in the carboxylate group. The difference spectra clearly show that 
the carboxylate anions are present in the composite and their bands are shifted compared to the sodium salt, i.e., the anion interacted with the layers of the LDH.

X-ray absorption spectra of the pristine CaFe-LDH and the L-prolinate-CaFe-LDH samples are depicted in Figure 35.
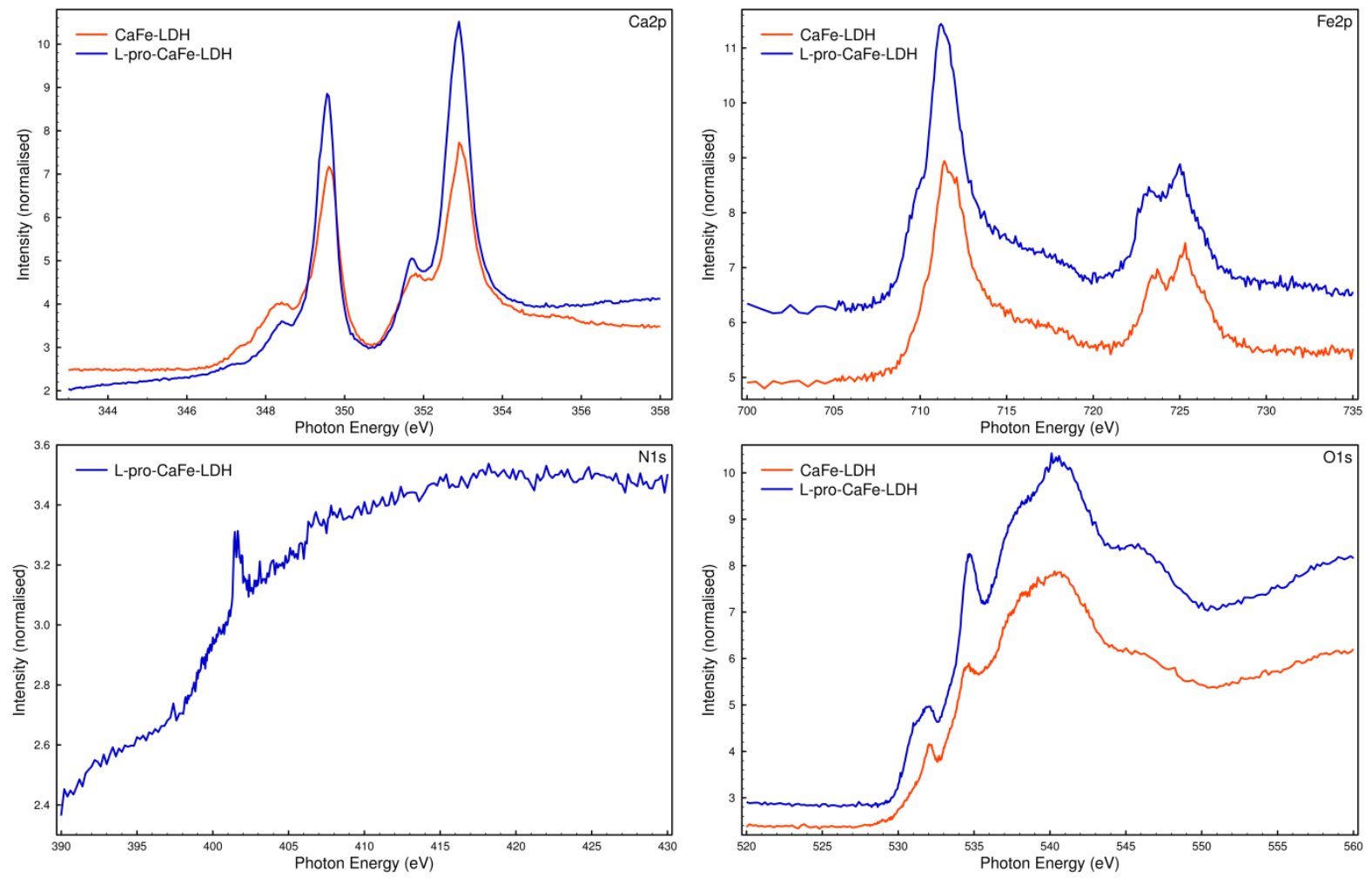

Figure 35. X-ray absorption spectra of the L-prolinate-CaFe sample performed around the Ca2p, $\mathrm{Fe} 2 \mathrm{p}$, N1s and $\mathrm{Ols}$ absorption edges.

It is to be observed that the intercalated prolinate does not perturb the structure of the sample neither that of the $\mathrm{LDH}$ nor the $\mathrm{Ca}(\mathrm{OH})_{2}$. One may think that it is not even intercalated, however, the N1s X-ray absorption spectra clearly verifies its presence. Moreover, the shoulder at $531 \mathrm{eV}$ and the intensified peak around $547 \mathrm{eV}$ the $\sigma \rightarrow \pi^{*}$ and $\pi \rightarrow \sigma^{*}$ transitions of its carboxylate bond. ${ }^{125}$

In conclusion, it can be said with great certainty that the intercalation was successful in all cases, but the application of different solvent mixtures during the synthesis affected tremendously the arrangement of the anions between the layers, and thus, the basal distances of the LDHs.

After verifying that the organic anions were intercalated indeed, whichever solvent mixture was used, through the combination of the interlayer distance values and the dimension data of the organic anions a schematic representation of the possible arrangement of the anions between the layers may be given (Table 7). It can be envisaged that when 
aqueous acetone was used during preparation, both the indole-2-carboxylate and the dihydroindole-2-carboxylate fit between the layers if they are located perpendiculary. Upon using aqueous ethanol the anions can be accommodated in two layers of horizontal orientation. By the calculated parameters it is also possible that one layer of anions are intercalated in a vertical fashion, however, since the UV-Vis results indicated that the amount of both incorporated anions were nearly the same, the bilayer arrangement seems plausible even when the ethanolic mixture was applied in the synthesis. Nevertheless, the dimension data for the DL-2-piperidine-carboxylate and the L-prolinate anion allow the perpendicular orientation to the layers.

This phenomenon is not entirely unprecedented, although it was not observed for the effects of solvents yet. For fatty acids there are three possible assemblies: monolayer, bilayer and partial overlap packing. The various arrangements were induced by the amount of accessible anion or the $\mathrm{pH} .{ }^{126,127}$ 
Table 7. A schematic representation of the possible arrangement for the intercalated anions of the compounds between the layers of CaFe-LDH in both solvents used for the syntheses.

Intercalated

organic

compound
Schematic representation of a possible arrangement

Structural formula

indole-2-

carboxylic

acid<smiles>O=C(O)c1cc2ccccc2[nH]1</smiles>
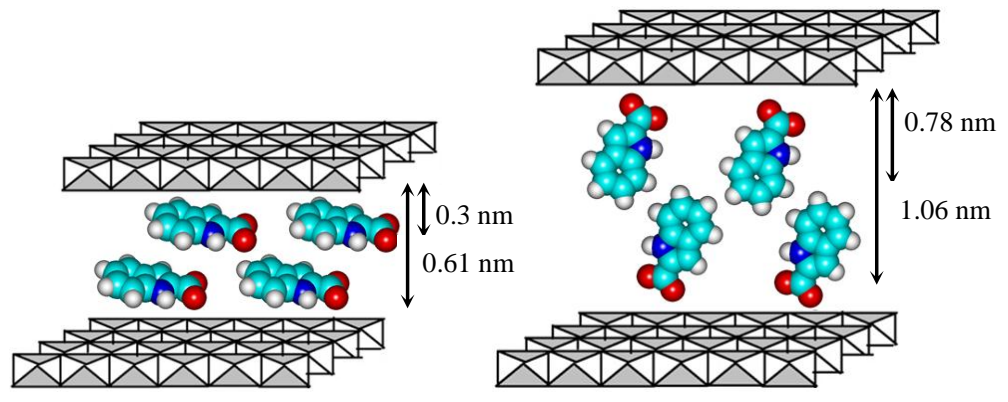

dihydroindole2-carboxylic acid
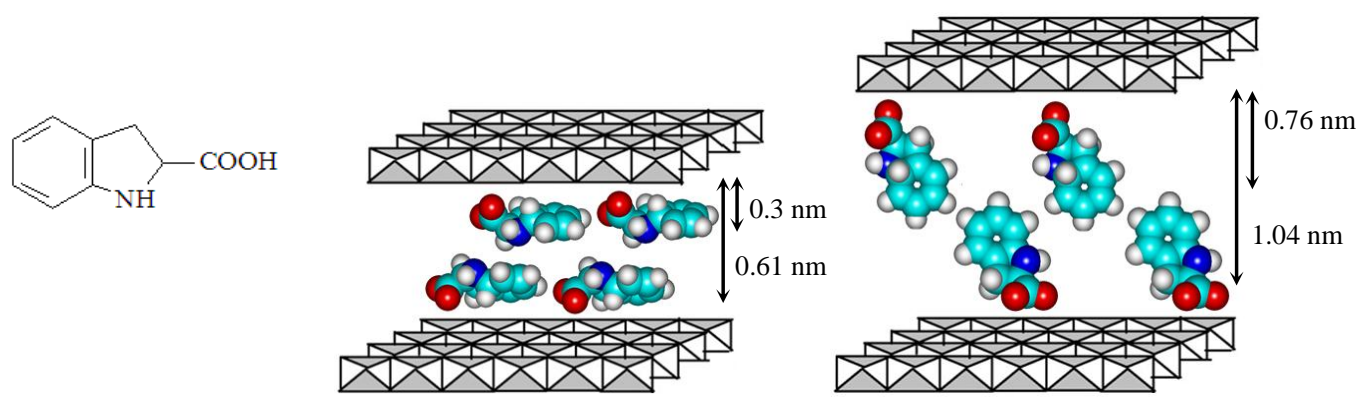

DL-2piperidinecarboxylic acid
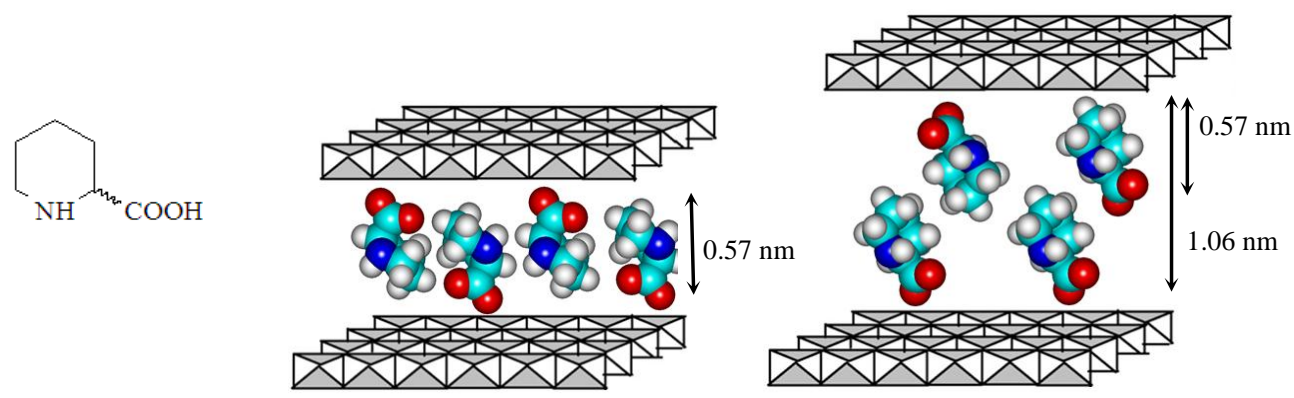

L-proline

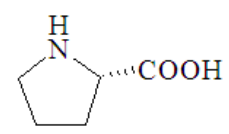

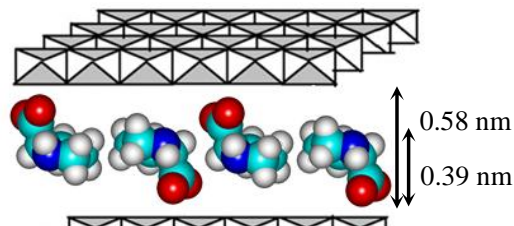

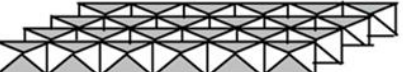




\subsection{The application of pristine CaFe-LDH as a catalyst in an epoxidation reaction}

Among other applications layered double hydroxides are very often used in catalysis, mostly in base-catalyzed reactions. ${ }^{71}$ Usually, they are employed as catalyst precursors. After calcination, the layered structure collapses and the catalytic activity of the resulting mixed oxide often increases, because of the presence of many defects in its structure. ${ }^{128}$ To extend the scope of catalytic applications it was decided to search for reaction that is catalysed by the pristine, uncalcined LDH. Preferably, the reaction should be synthetically useful as well. After surveying the literature, I ended up with the epoxidation of electron-deficient carboncarbon double bonds of $\alpha, \beta$-unsaturated ketones using hydrogen peroxide as oxidant. An earlier study with the most commonly used MgAl-LDH revealed that the reaction was feasible. $^{128}$

The unsaturated ketone was 2-cyclohexene-1-one, the oxidant was $30 \mathrm{wt} \% \mathrm{H}_{2} \mathrm{O}_{2}$ and the reaction was performed in methanol at $298 \mathrm{~K}$ under vigorous stirring. A range of LDHs (CaFe-LDH, MgFe-LDH, CaAl-LDH) were used in uncalcined forms, and for comparison the reaction was performed over $\mathrm{TiO}_{2}(\mathrm{P} 25)$, calcined $\mathrm{CaFe}-\mathrm{LDH}$ as well as without catalyst. The epoxidation of 2-cyclohexene-1-one takes place according to the following equation:

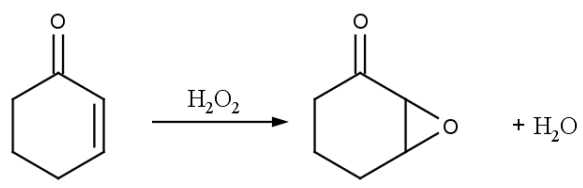

Table 8. Conversion data of the epoxidation reaction over various $\mathrm{LDHs}$ and other catalysts in methanol as solvent.

\begin{tabular}{lc}
\hline Catalyst & $\begin{array}{c}\text { Conversion }(\%) \\
\text { after } \mathbf{1 2 0} \text { min }\end{array}$ \\
\hline without catalyst & $<1$ \\
$\mathrm{TiO}_{2}(\mathrm{P} 25)$ & 8 \\
calcined $\mathrm{Ca}_{3} \mathrm{Fe}-\mathrm{LDH}$ & 10 \\
$\mathrm{Mg}_{2} \mathrm{Al}-\mathrm{LDH}$ & 19 \\
$\mathrm{Mg}_{2} \mathrm{Fe}-\mathrm{LDH}$ & 15 \\
$\mathrm{Ca}_{2} \mathrm{Al}-\mathrm{LDH}$ & 27 \\
& \\
$\mathrm{Ca}_{2} \mathrm{Fe}-\mathrm{LDH}$ & 47 \\
$\mathbf{C a}_{3} \mathrm{Fe}-\mathrm{LDH}$ & $\mathbf{3 6}$ \\
$\mathrm{Ca}_{4} \mathrm{Fe}-\mathrm{LDH}$ & 29 \\
\hline
\end{tabular}

In the first set of experiments, all reactions have been going on for $2 \mathrm{~h}$ and the degree of conversion was determined. The results are summarised in Table 8. The reproducibility of the data was within $\pm 1 \%$. Each LDH-type was more active than the calcined $\mathrm{CaFe}$ $\mathrm{LDH}$ proving that the layered structure was advantageous for the epoxidation of 2-cyclohexen-1-one. It is worth to notice that the hydrocalumite-type LDHs resulted better conversions in the studied 
cases than the hydrotalcite-like layered materials. Varying the $\mathrm{Ca}(\mathrm{II}): \mathrm{Fe}(\mathrm{III})$ ratio had some minor effect on the activity rendering: $\mathrm{Ca}_{2} \mathrm{Fe}-\mathrm{LDH}$ is the most active, affording $47 \%$ yields of the 2,3-epoxycyclohexanone. It is known that perfect hydrocalumite structure only forms at this composition, pointing again at the observation that the layered structure suits best to this reaction. However, as was discussed before, as far as stability is concerned the $\mathrm{Ca}$ (II) : $\mathrm{Fe}$ (III) $=3: 1$ ratio is the best, and since the activity was just slightly lower than with $\mathrm{Ca}_{2} \mathrm{Fe}-\mathrm{LDH}$, the $\mathrm{Ca}_{3} \mathrm{Fe}-\mathrm{LDH}$ was used for temperature-, time- and solvent dependence studies.

The effect of reaction temperature on the efficiency of hydrogen peroxide utilisation was also examined. Here methanol was the solvent and the results are summarised in Table 9.

The highest efficiency in hydrogen

Table 9. Conversion data of the epoxidation reaction over uncalcined $\mathrm{Ca}_{3} \mathrm{Fe}-\mathrm{LDH}$ using methanol as solvent.

\begin{tabular}{lc}
\hline Temperature & $\begin{array}{c}\text { Conversion (\%) } \\
\text { after } \mathbf{1 2 0} \text { min }\end{array}$ \\
\hline $15^{\circ} \mathrm{C}$ & 27 \\
$25{ }^{\circ} \mathrm{C}$ & 36 \\
$40^{\circ} \mathrm{C}$ & 39 \\
$55{ }^{\circ} \mathrm{C}$ & 26 \\
$70^{\circ} \mathrm{C}$ & 29 \\
& \\
\hline Reaction time & Conversion (\%) \\
\hline 5 min & 2 \\
30 min & 11 \\
$1 \mathrm{~h}$ & 22 \\
$2 \mathrm{~h}$ & 36 \\
$4 \mathrm{~h}$ & 48 \\
$6 \mathrm{~h}$ & 56 \\
$24 \mathrm{~h}$ & 63 \\
& \\
\hline Catalyst & Conversion (\%) \\
\hline Ca $\mathrm{a}_{3}$ Fe-LDH & after $\mathbf{1 2 0}$ min \\
freshly prepared) & 36 \\
Reuse I & 36 \\
\hline
\end{tabular}
peroxide utilization was observed when the reaction was performed at mild temperatures. The increase of reaction temperature over $40{ }^{\circ} \mathrm{C}$ resulted in a slight decrease in efficiency. Epoxidation at $40{ }^{\circ} \mathrm{C}$ was the most suitable from the standpoints of hydrogen peroxide efficiency and the reaction rate, in good agreement with the observations of Yamaguchi et al. ${ }^{128}$

In order to achieve the maximum conversion, a time-dependence study was performed. The results are summarised in Table 9. The epoxidation of 2-cyclohexen-1-one carried out with the as-prepared $\mathrm{Ca}_{3} \mathrm{Fe}-\mathrm{LDH}$ catalyst in methanol solvent at $25{ }^{\circ} \mathrm{C}$ leads to $36 \%$ conversion in $2 \mathrm{~h}$ and $63 \%$ in $24 \mathrm{~h}$ with 2,3-epoxycyclohexanone as the only product (Figure 36). The time dependence data were fitted based on

first order kinetics. As a result, the experiments strictly follow the first order kinetics with $\mathrm{k}=0.0068 \pm 0.0003 \mathrm{~min}^{-1}$. It may point out that there is no catalyst degradation, but this fact was also checked explicitly. The further increase of the conversion may be due to other 
effects, e.g. the conscious choice of solvent. The use of a solid LDH makes the workup procedure very simple. The catalyst could easily be separated from the reaction mixture by a simple filtration. The recovered catalyst was then reused in the same reaction (Table 9). The oxidation using the spent catalyst gave the epoxyketone with the same conversion (under the same conditions) as those of the first run. The conversion was not decreased even after the catalyst was recycled twice.

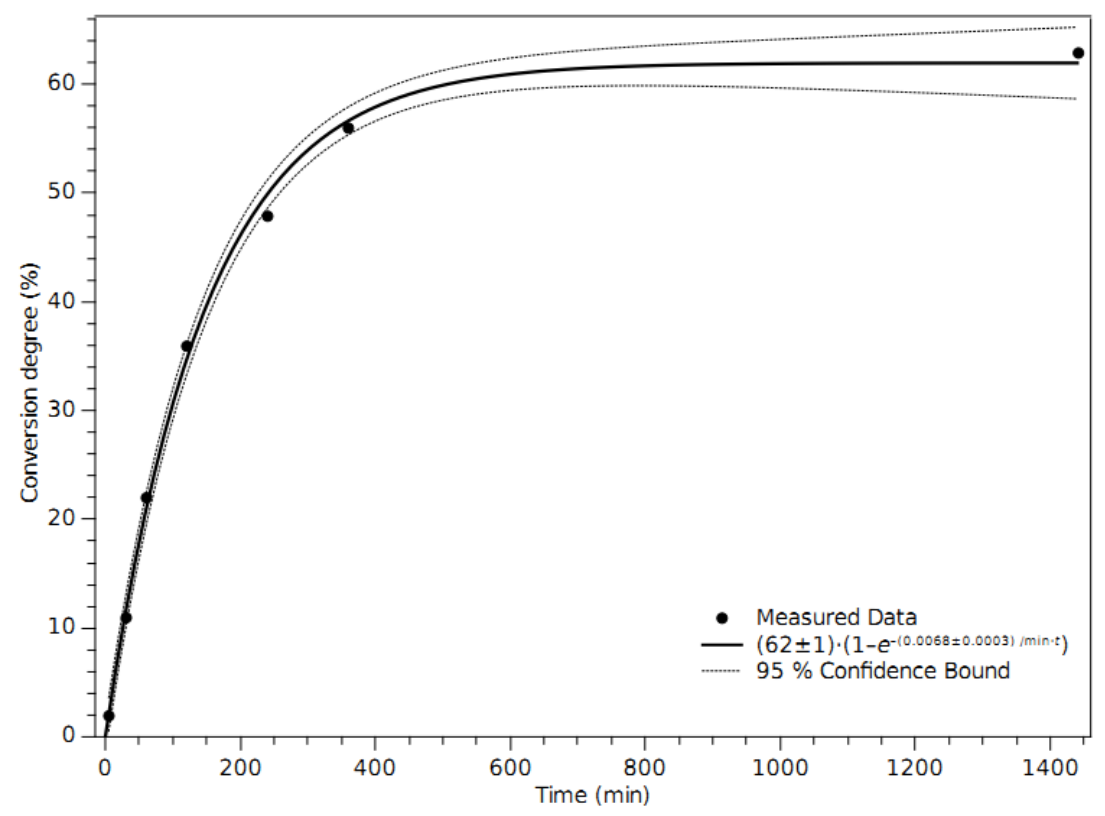

Figure 36. Catalytic activity of the $\mathrm{Ca}_{3} \mathrm{Fe}-\mathrm{LDH}$ in the epoxidation of 2-cyclohexen-1-one in methanol solvent at $25^{\circ} \mathrm{C}$.

Table 10. Conversion data for the epoxidation reaction after 2 hour over uncalcined $\mathrm{Ca}_{3} \mathrm{Fe}-\mathrm{LDH}$ using various solvents.

\begin{tabular}{lc}
\hline Solvent & Conversion $(\boldsymbol{\%})$ \\
\hline 2-methyl-2-propanol & $<1$ \\
ethanol & 27 \\
methanol & 36 \\
acetone & 18 \\
1,4-dioxane & 12 \\
formamide & 58 \\
cyclohexene & 42 \\
n-hexane & 49 \\
\hline
\end{tabular}

Altering the solvent had occasionally dramatic effect on the conversion and thus the reactivity of the catalyst. The highest conversion was observed in formamide; n-hexane and cyclohexene were better solvents than methanol. In turn methanol proved to be a better solvent for this reaction than ethanol. The rest of the solvents, 2-methyl-2propanol, acetone and 1,4-dioxane performed poorly in this reaction (Table

10). The excellent activity in the presence of formamide is most likely to be due to the delamination of the layers ${ }^{129}$ making the basic sites significantly more accessible. If the solvent is alcohol, lengthening the carbon-chain results in a dramatic decline in conversion. 
The explanation of the poor conversion rate in 1,4-dioxane may lie in the effect of the solvent on the layered double hydroxide. It is similar to that of heat-treatment, in the sense that both destroy the structure, as Figure 37 attests.

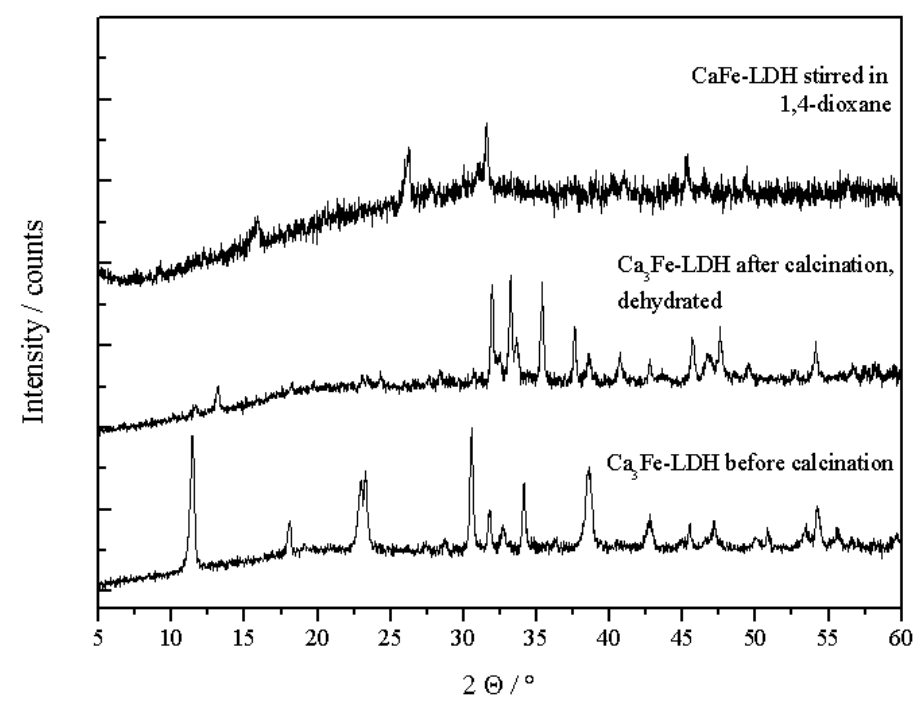

Figure 37. The effect of heat-treatment $\left(500^{\circ} \mathrm{C}\right)$ and treatment with 1,4-dioxane on $\mathrm{Ca} \mathrm{Fe}_{3} \mathrm{LDH}$.

The catalytic properties of intercalated derivatives (indole-2-carboxylate-CaFe-LDH and L-prolinate- $\mathrm{Ca}_{3} \mathrm{Fe}-\mathrm{LDH}$ ) were also examined. It is apparent from Table 11 that the quality of the intercalated anion did not affect the conversion of 2-cyclohexen-1-one. Rather, the solvent mixture in which the intercalated LDHs were synthesised had some effects on the conversions. In both cases they increased when the ethanol/water $/ \mathrm{NaOH}$ mixture were used. It may be due to the solvent residue in the composite materials rather than the arrangement of the anions since, e.g., for L-prolinate-LDH the basal spacing was similar irrespective to the solvent mixture applied in the syntheses.

Table 11. Conversion data of the epoxidation reaction after 2 hour over various intercalated LDHs prepared in different solvents and the dodecylbenzenesulphonate-treated (DBS-treated) LDHs.

\begin{tabular}{lc}
\hline Catalyst & Conversion (\%) \\
\hline L-prolinate- $\mathrm{LDH}$ EtOH$/ \mathrm{H}_{2} \mathrm{O}$ & 55 \\
L-prolinate- $\mathrm{LDH}$ acetone $/ \mathrm{H}_{2} \mathrm{O}$ & 37 \\
indole-2-carboxylate- $\mathrm{LDH}$ EtOH$/ \mathrm{H}_{2} \mathrm{O}$ & 47 \\
indole-2-carboxylate- $\mathrm{LDH}$ acetone $/ \mathrm{H}_{2} \mathrm{O}$ & 37 \\
& \\
DBS-LDH & 35 \\
DBS + LDH (separate) & 27 \\
\hline
\end{tabular}


This fact could be confirmed by the data obtained from reactions with the dodecylbenzenesulphonate (DBS) intercalated $\mathrm{Ca}_{3} \mathrm{Fe}-\mathrm{LDHs}$. DBS is an anionic surfactant which inhibits the epoxidation of the unsaturated ketones. ${ }^{128}$ It is consistent with the fact, on adding the $\mathrm{Ca}_{3} \mathrm{Fe}-\mathrm{LDH}$ and the DBS to the reaction mixture separately, the conversion of 2cyclohexen-1-one decreased. However, when the dodecylbenzenesulphonate was incorporated into the layers by the dehydration-rehydration method (ethanol/water solvent mixture was used), the surfactant had no effect on the conversion. 


\subsection{Preparation of immobilised organocatalysts and their application in cross- aldol dimerisation}

In the organocatalytic transformations, the organocatalysts are in the same phase as the reactants and the products in most cases. However, if they are attached to a solid or quasisolid support, the work-up procedure is made easier on one hand, and the catalyst can be recycled making the reactions more benign to the environment on the other. No wonder that the second generation organocatalysts are organic molecules immobilised on various supports. There are many possibilities of immobilisation (covalent grafting, non-covalent attachment [ion exchange, hydrogen bonding interactions], biphasic catalysis [organocatalyst bonded to ionic liquids]) and the support can be of many kinds (functionalised/modified resins, silica gel or silicates, cyclodextrins, etc.). It was not surprising that proline was also immobilised ${ }^{130,131}$ using polyethylene-glycol (PEG), polystyrene, various forms of silica gel and silicates, alumina, magnetite, dendrimers, ionic liquids, etc. ${ }^{132,133}$ These catalysts were tested in aldol dimerisation as well, in some cases in types providing enantiomers. Both the activities and enantioselectivities of aldol dimerisation largely depended on the reaction conditions as well as the supports and the modes of immobilisation.

In the followings, the behaviour of various functionalised materials are examined in this reaction. First, chloropropylated silica gel was chosen as support and N- or C-protected Lproline was covalently grafted on it. For immobilisation either Boc-protected L-proline (Boc-Pro- $\mathrm{OH})$ or C-protected L-proline $\left(\mathrm{H}-\mathrm{Pro}-\mathrm{OCH}_{3}\right)$ were used (Figure $26 a$ ) and $b$ )) and after covalent grafting (esterification or $\mathrm{N}$-alkylation were the two reactions), the immobilised amino acids were deprotected. The materials were used in the aldol dimerisation reaction in these forms. For comparison the catalytic activity of the commercially available L-prolinol anchored on polystyrene (Figure $26 c$ )) was also investigated.

a)

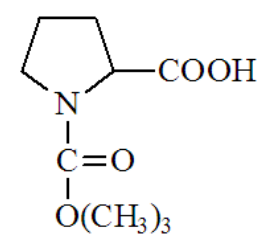

b)

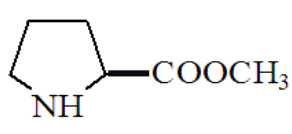

c)

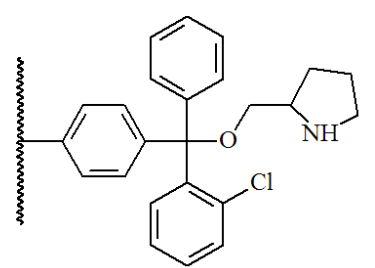

Figure 38. The covalently grafted a) N-protected L-proline (tert-butoxycarbonyl-L-proline); b) $C$ protected L-proline (L-proline methylester) and c) resin-anchored L-prolinol-2-chlorotrityl ether.

Layered double hydroxides were very sparingly applied as host for the intercalation of deprotonated proline. ${ }^{134,135}$ It is surprising, because they should be ideal hosts. Previously 
enantiopure proline was only intercalated into $\mathrm{MgAl}-\mathrm{LDH}$. The intercalated structures were tested in aldol dimerisation-condensation of benzaldehyde and acetone. The catalysts were active and selective towards dimerisation. Both low (6\%, Choudhary et al. $\left.{ }^{135}\right)$ and high $(94 \%$, An et $a l .{ }^{134}$ ) enantioselectivity values were detected. In order to extend the scope of the studied organocatalyst immobilised in LDHs, beside proline, another N-containing saturated cyclic amino acid (pipecolinic acid) was used for intercalation. The host was also different, CaFe-LDH was applied.

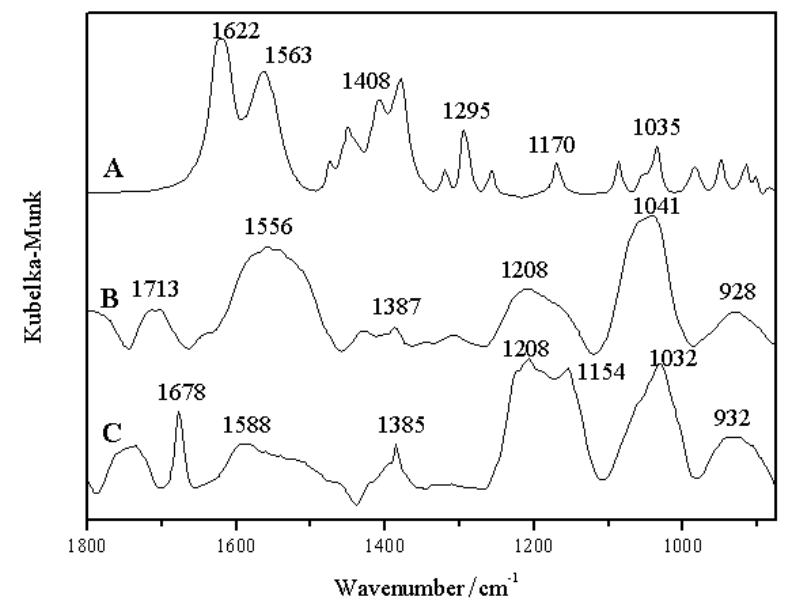

Figure 39. The FT-IR spectrum of (A) L-proline, (B) SG-Pro-OH (spectrum of SG is subtracted), (C) $H-P r o-O-S G$ (spectrum of $S G$ is subtracted).

From the detailed comparative analysis of the IR spectra of the amino acid and the composite materials, one could see if the amino acids attached were intact or not (Figure 39). To make comparison easier the spectrum of the support was subtracted from that of the composite and it was compared to that of the pristine proline in the most informative region. It is clear from trace A (see the bands between $1400-1600 \mathrm{~cm}^{-1}$ ) that the pristine proline was in zwitterionic form.

When L-proline was immobilised via the $\mathrm{N}$ atom, the compound is present in protonated form - the carboxylate doublet disappeared and only the carbonyl vibration is seen at $1713 \mathrm{~cm}^{-1}$. The wide, medium intensity band $\left(1208 \mathrm{~cm}^{-1}\right)$ indicates aliphatic tertiary amine while the intense band around $1000 \mathrm{~cm}^{-1}$ refers the remaining aliphatic ring. These observations verify that the covalent immobilisation of L-proline through its nitrogen atom was successful.

In trace $\mathrm{C}$, the wide band at $1032 \mathrm{~cm}^{-1}$ indicates that the ring is kept during covalent grafting and deprotection. The relatively intense bands at $1678 \mathrm{~cm}^{-1}$ and $1208 \mathrm{~cm}^{-1}$ are typical 
for esters indicating that the attachment of the N-protected proline via an esterification reaction was successful.

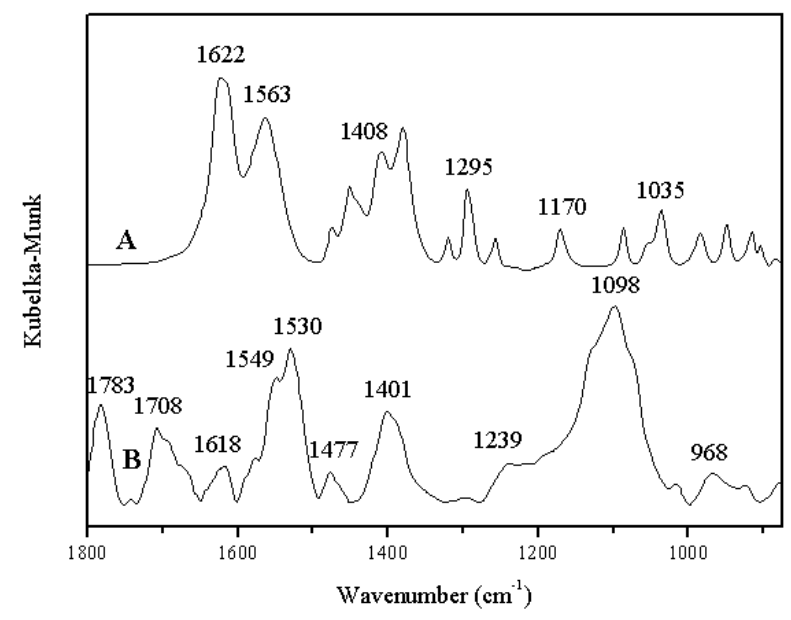

Figure 40. The FT-IR spectrum of (A) L-proline, (B) resin-anchored L-prolinol-2-chlorotrityl ether.

The resin-anchored L-prolinol-2-chlorotrityl ether was a commercial product with limited amount of characteristic data provided by the supplier. Since I intended to use its resinanchored variety for similar purposes as the functionalised materials that I prepared, it seemed worthwhile to learn about its properties. The wide, intense and structured vibration at $1098 \mathrm{~cm}^{-1}$ includes ring deformation vibrations as well as vibration typical for the secondary nitrogen of the ring as shoulders (Figure 40).

The detailed characterisation of L-prolinate-LDH and DL-2-piperidine-carboxylate-LDH was described in earlier (Ch. 5.2., pp 46-59.). For the catalytic studies the samples prepared in $\mathrm{EtOH} / \mathrm{H}_{2} \mathrm{O} / \mathrm{NaOH}$ mixture were used.

\subsubsection{Composite materials as catalysts for aldol dimerisation reactions}

The synthesised functionalised materials were tested in the following reactions (Figure 41)

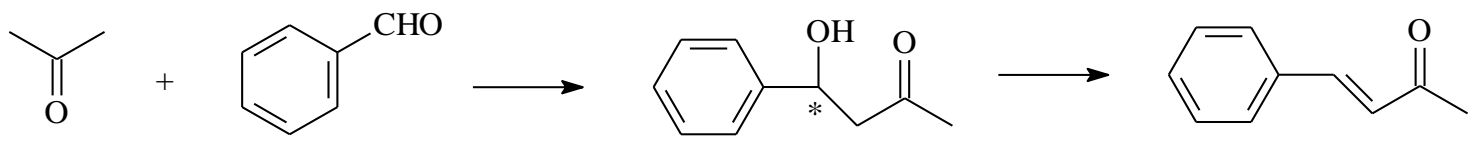

(a)

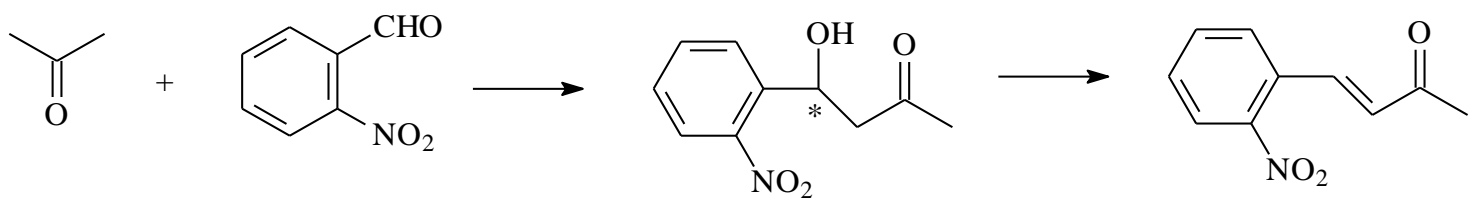

(b) 


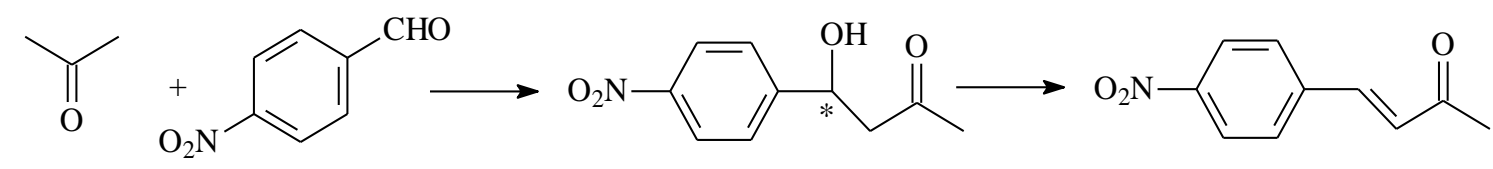

(c)

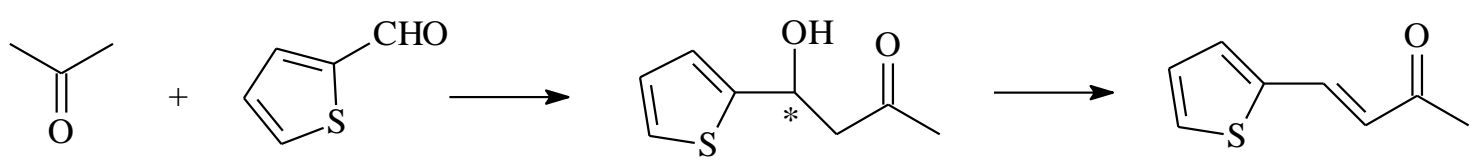

(d)

Figure 41. Aldol dimerisation reactions and the accompanying condensations.

The test reactions were characterised by three sets of data: conversion, selectivity (rate of dimerisation $v s$. condensation) and enantioselective excess (by definition: $e e=$ $[R]-[S] /[R]+[S]$, where $R$ and $S$ refer to the absolute configuration).

The purchased catalyst was thoroughly studied, because significantly larger quantities were available and thus it was possible to study the effect of solvents, and moreover the processing and analysis of the reaction mixture were easier. 


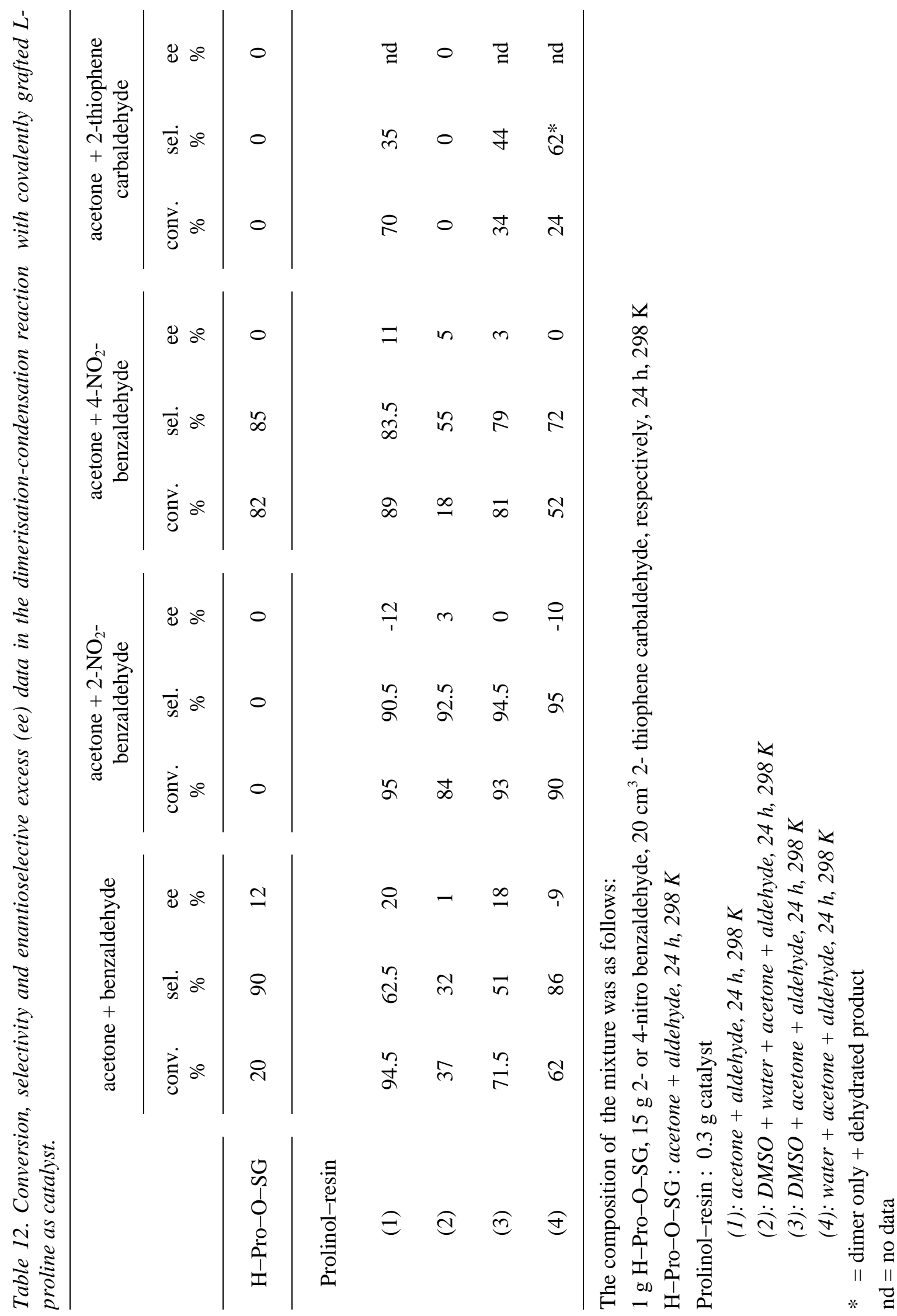


According to the results detailed in Table 12 one can make the following observations: if L-proline is grafted to the surface of the silica gel through its $\mathrm{N}$-terminal, there is no aldol dimerisation. If L-proline is grafted to the surface of the silica gel through its C-terminal, the composite catalysed the dimerisation of acetone and benzaldehyde with moderate and 2nitrobenzaldehyde with high conversion rates, and with high selectivities. Moderate enantioselectivity was achieved in the reaction with benzaldehyde. There was no transformation with any of the other reactants, but, perhaps, an optimisation of the reaction conditions would change this situation.

The resin-anchored L-prolinol-2-chlorotrityl ether was active with almost every reactant pair, with the exception of acetone-2-thiophene-carboxaldehyde in DMSO-water solvent mixture. Generally speaking, this solvent (mixture) proved to be the worst option among the solvents or solvent combinations tried. When a reaction occurs, the conversion and the selectivity of the dimerisation were good and, occasionally, both data were very high (this was the case in the acetone-2-nitrobenzaldehyde reactant pair, in particular). As far as enantioselectivity of the dimerisation is concerned, many nonzero ee values were obtained, but none of them is unusually high. It is worth to note that for two of reactant combinations (acetone-benzaldehyde and acetone-2-nitrobenzaldehyde) the choice of solvent influenced the direction of rotating the plane-polarised light of the product.

Unfortunately, the enantioseparation of the dimers from the reactant combination of acetone-2-thiophene-carbaldehyde was not successful, therefore no information could be gathered on the enantioselecivity of the dimerisation. It should be noted that in this reactant combination products with much higher molecular weights than thus of the dimers were found in almost all cases (except for the reaction in water). The resulting products have not been identified yet.

It was hoped that providing a sterically confined environment with the L-prolinate-CaFeLDH catalyst system the selectivity of the dimerisation reaction would be significantly influenced.

The immobilised organocatalysts (L-prolinate-CaFe-LDH and DL-pipecolinate-CaFeLDH) were tested in the cross-aldol dimerisation-condensation of benzaldehyde and acetone. It was found that both catalysts were active and gave the dimer as well as the condensation product. Let me note that there was no reaction with the pristine $\mathrm{LDH}$ at room temperature. The reuse of the L-prolinate-CaFe-LDH catalyst was also attempted. The composition of the mixture was as follows: $1 \mathrm{~cm}^{3}$ of $\mathrm{H}_{2} \mathrm{O}, 4 \mathrm{~cm}^{3}$ of acetone, $1 \mathrm{~cm}^{3}$ of benzaldehyde, $0.3 \mathrm{~g}$ of 
catalyst. The mixture was vigorously stirred for $24 \mathrm{~h}$ at $298 \mathrm{~K}$. Acetone served as the reactant as well as the solvent, water was used as proton source. The L-prolinate-CaFe-LDH catalyst was reused twice without any special reactivation except rinsing it with acetone. Results obtained are summarised in Table 13.

Table 13. Conversion, selectivity and enantioselective excess (ee) data in the dimerisationcondensation reaction of acetone and benzaldehyde catalysed by L-prolinate and DL-pipecolinate immobilised between the layers of $\mathrm{CaFe}-\mathrm{LDH}$

\begin{tabular}{lcccc}
\hline Materials & $\begin{array}{c}\text { Convers. } \\
(\%)\end{array}$ & $\begin{array}{l}\text { Selectivity of } \\
\text { dimerization (\%) }\end{array}$ & $\begin{array}{l}\text { Selectivity of } \\
\text { condensation (\%) }\end{array}$ & ee (\%) \\
\hline CaFe-LDH & 0 & 0 & 0 & 0 \\
L-prolinate-CaFe-LDH & & & 15 & 53 \\
$\quad$ Freshly prepared & 3 & 85 & 12 & 12 \\
$\quad$ Reuse I & 19 & 88 & 23 & 6 \\
$\quad$ Reuse II & 59 & 76 & 5 & 0 \\
DL-pipecolinate-CaFe-LDH & 0.5 & 95 & & \\
\hline
\end{tabular}

At room temperature, initially, the activity of the intercalated materials was low. Nevertheless, selectivity towards dimerisation was high and the ee value with Lprolinate-CaFe-LDH was appreciable. The catalyst could be recycled and then gradual activation and the gradual decrease in both dimerisation selectivity and enantioselectivity were observed. This observation is in complete coincidence with the observation that under basic conditions the carboxylate ions undergo enolisation. ${ }^{136}$ Due to this reaction the chirality of the $\alpha$-carbon atom is lost. Since LDHs are known to be basic materials they catalyse enolisation. The other catalyst DL-pipecolinate-CaFe-LDH that is, had low activity in the cross-aldol dimerisation-condensation reaction, however its selectivity for condensation was very high. Since no chiral information was introduced into the system, racemate was formed. 


\section{Conclusions}

Layered Double Hydroxides (LDH) form a unique group of clays that have an anionic exchange capability. Contrary to the large number of cation exchanger materials, the number of known anion-exchange frameworks is rather limited. LDHs are known as structures consisting of positively-charged mixed-metal hydroxide layers, between which balancing anions and water molecules are found.

During the experimental work leading to this dissertation, a variety of $\mathrm{MgFe}$ hydrotalcitelike and $\mathrm{CaFe}$ hydrocalumite-like compounds was synthesised using co-precipitation. The synthesised materials were extensively characterised by various methods like X-ray diffractometry (XRD), inductively coupled plasma-optical emission, IR, ${ }^{57} \mathrm{Fe}$ Mössbauer and near edge X-ray absorption fine structure spectroscopies, thermogravimetric analysis, transmission and scanning electron microscopies and scanning electron microscopy coupled with energy dispersive X-ray spectroscopy.

XRD patterns for the synthesised LDHs exhibited characteristic features indicative of an ordered layered material. The optimum synthesis conditions were identified both for $\mathrm{CaFe}$ and $\mathrm{MgFe}-\mathrm{LDHs}$ and it was confirmed that if the LDHs are intended to be used as hosts of intercalated anions, the syntheses should be performed under $\mathrm{N}_{2}$ blanket and the $\mathrm{NaOH}$ concentration should not exceed $3 \mathrm{M}$. It has been found that on increasing $\mathrm{Ca}$ (II) to $\mathrm{Fe}$ (III) ratios from 2 to 6 , the quantity of $\mathrm{Ca}(\mathrm{OH})_{2}$ almost linearly increases from $0 \%$ to $\sim 60 \%$. At the same time stabilities of the materials increased - the ideal hydrocalumite structure $(\mathrm{Ca}(\mathrm{II}): \mathrm{Fe}(\mathrm{III})=2)$ is the least stable. ${ }^{57} \mathrm{Fe}$ Mössbauer measurements revealed that $\mathrm{Fe}(\mathrm{III})$ was in a high-spin, somewhat disordered octahedral environment in both CaFe- and MgAl-LDHs at every composition. The layer thickness, inevitable for assuming reasonable spatial arrangements was estimated from TEM dark-field image and was measured to be $0.19 \mathrm{~nm}$, in good agreement with the $0.178 \mathrm{~nm}$ determined by others from high-precision XRD data.

The subsequent intercalation of various $\mathrm{N}$-containing carboxylic acid anions was performed by the dehydration-rehydration method. The structures as well as the morphologies of the composite samples have been characterised by the instrumental techniques listed above complemented with UV-Vis spectroscopy and molecular modelling. Particular attention was paid to the influence of solvent mixture used during preparation; various solvent mixtures resulted in different interlayer distances and thus different arrangements of the anions between the layers. The intercalation chemistry of $\mathrm{Ca}_{3} \mathrm{Fe}-\mathrm{LDH}$ could be tremendously influenced by the choice of solvent mixture used. The dimensions of the intercalated anions 
were estimated form those of the parallelepipeds used for the inclusion of the anions to be intercalated optimised by the PM3 semiempirical quantum chemical method. These dimensions gave clues for the reasonable prediction of the spatial arrangements of the anions in the interlamellar space. The ethanol : $\mathrm{H}_{2} \mathrm{O}: \mathrm{NaOH}$ and the acetone $: \mathrm{H}_{2} \mathrm{O}: \mathrm{NaOH}$ solvent mixtures allowed the intercalation of $\mathrm{N}$-containing aromatic, partially as well as fully saturated N-containing heterocycles in single and multilayers, respectively, while preserving the layered structure in both cases.

There is an increasing interest to environmentally benign heterogeneous catalytic processes in the chemical industry. It remains a continuous challenge to find highly active solid Brønsted-type basic catalysts that are able to bring about $\mathrm{C}-\mathrm{C}$ bond formation with good selectivity. Targeted transformations are various types of self- or cross-condensation reactions between aldehydes and ketones. The uncalcined CaFe-LDHs were found to be useful and efficient catalysts in an epoxidation reaction - they were significantly more active than the calcined derivatives. The epoxidation of 2-cyclohexen-1-one over uncalcined CaFe-LDHs were performed in various solvents (formamide, n-hexane, cyclohexene, methanol, ethanol, 2methyl-2-propanol, acetone and 1,4-dioxane) and temperatures. Formamide and $313 \mathrm{~K}$ were the most advantageous solvent and temperature mix, however, the reactions could be conducted with high activities in n-hexane, cyclohexane as well as in methanol and ethanol. The uncalcined $\mathrm{MgAl}$-hydrotalcite, $\mathrm{MgFe}$-hydrotalcite and $\mathrm{CaAl}$-hydrocalumite were less active than $\mathrm{CaFe}$-hydrocalumite, but still more efficient than the calcined derivatives (mixed oxides) or another oxide like titania.

L-proline has for many years been widely used as a chiral organocatalyst for bond forming organic reactions. It efficiently catalyses the aldol reaction with a range of ketones and aldehydes, resulting in good yields and appreciable enantiomeric excesses. A great deal of research has also been dedicated to catalyst immobilization, with desire to achieve easy product isolation and efficient recycling protocols. Covalently functionalised silica gel could be prepared by immobilising N- or C-protected L-proline on chloropropylated silica gel. After deprotection L-proline anchored only at the C-terminal was active in cross-aldol dimerisation of acetone and benzaldehyde with moderate and 2-nitrobenzaldehyde with high conversion rates, and with high selectivities. Moderate enantioselectivity was achieved in the reaction with benzaldehyde. The commercially available L-prolinol anchored on polystyrene resulted in dimers of moderate enantioselectivities in a similar reaction, but with a larger variety of aldehydes. So it has been found experimentally that for the catalytic activities of covalently immobilised N-containing heterocycles freely available secondary nitrogens are inevitable. 
The above-listed results clearly attest that layered double hydroxides are versatile materials. They can be functionalised in various ways with relative ease and, among many possible applications, they can be tailored to reactions that can be useful to laboratory use as well as in the fine chemical industry. 


\section{REFERENCES}

${ }^{1}$ W. Feitknecht, G. Fischer, Helv. Chim. Acta 18 (1935) 555-569.

${ }^{2}$ M. Catti, G. Ferraris, S. Hull, A. Pavese, Phys. Chem. Miner. 22 (1995) 200-206.

${ }^{3}$ D. Srankó, M. Sipiczki, É.G. Bajnóczi, M. Darányi, Á. Kukovecz, Z. Kónya, S.E. Canton, K. Norén, P. Sipos, I. Pálinkó, J. Mol. Struct. 993 (2011) 62-66.

${ }^{4}$ S. Velu, K. Suzuki, M. Okazaki, T. Osaki, S. Tomura, F. Ohashi, Chemistry of Materials 11 (1999) 2163-2172.

${ }^{5}$ A.I. Khan, D. O'Hare, J. Mater. Chem. 12 (2002) 3191-3198.

${ }^{6}$ G. Alberti, U. Costantino: Solid state supramolecular chemistry: Two- and three-dimensional inorganic networks, In: G. Alberti, T. Bein (Eds.), Comprehensive Supramolecular Chemistry, vol. 7, Pergamon and Elsevier Science, Oxford, (1996)

${ }^{7}$ J.T. Kloprogge, D. Wharton, L. Hickey, R.L. Frost, Am. Mineral. 87 (2002) 623-629.

${ }^{8}$ F. Cavani, F. Trifiró, A. Vaccari, Catal. Today 11 (1991) 173-301.

${ }^{9}$ A.V. Radha, P.V. Kamath, C. Shivakumara, Acta Cryst. B 63 (2007) 243-250.

${ }^{10}$ M. Vucelic, W. Jones, G.D. Moggridge, Clays Clay Miner. 45 (1997) 803-813.

${ }^{11}$ V. Rives, In: Layered double Hydroxides: Present and future, Nova Science Publisher, New York (2001).

${ }^{12}$ R.C. Peterson, R.J. Hill, G.V. Gibbs, Can. Mineral. 17 (1979) 703-711.

${ }^{13}$ G.W. Brindley, C.C. Kao, Phys. Chem. Miner. 10 (1984) 187-191.

${ }^{14}$ K. Shinoda, N. Aikawa, Phys. Chem. Miner. 25 (1998) 197-202.

${ }^{15}$ A.S. Bookin, V.A. Drits, Clays Clay Miner. 41 (1993) 551-557.

${ }^{16}$ A.S. Bookin, V.I. Cherkashin, V.A. Drits, Clays Clay Miner. 41 (1993) 558-564.

${ }^{17}$ V. Fernon, A. Vichot, P. Colombet, H. van Damme, F. Bégin, Mater. Sci. Forums 152-153 (1994) 335-338.

${ }^{18}$ M. Ecker, H. Pöllmann, Mater. Sci. Forums 166-169 (1994) 565-570.

${ }^{19}$ M. Sacerdoti, E. Passaglia, N. Jb. Miner. Mh. (1988) 462-475.

${ }^{20}$ M. Belloto, B. Rebours, O. Clause, J. Lynch, D. Bazin, E. Elkaim, J. Phys. Chem. 20 (1996) 8527-8534.

${ }^{21}$ I. Rousselot, C. Taviot-Guého, F. Leroux, P. Léone, P. Palvadeu, J.-P. Besse, J. Solid State Chem. 167 (2002) 137-144.

${ }^{22}$ T.-H. Kim, I. Heo, S.-M. Paek, C.-B. Park, A.-J. Choi, S.-H. Lee, J.-H. Choy, J.-M. Oh, Bull. Korean Chem. Soc. 33-36 (2012) 1845-1850.

${ }^{23}$ O.P. Ferreira, O.L. Alves, D.X. Gouveia, A.G. Souza, J.A.C. de Paiva, J. Mendes, J. Solid State Chem. 177 (2004) 3058-3069.

${ }^{24}$ H.C. Hansen, C.B. Koch, Appl. Clay Sci. 10 (1995) 5-19.

${ }^{25}$ M.R. Schütz, A.E Schedl, F.E. Wagner, J. Breu App. Clay Sci. 54 (2011) 281-286.

${ }^{26}$ Ph. Refait, J.-M.R. Génin, Clay Miner. 32 (1997) 597-613.

${ }^{27}$ H.C.B. Hansen, C.B. Koch, Clays Clay Miner. 42 (1994) 170-179.

${ }^{28}$ S. Morlat-Thérias, C. Mousty, P. Palvadeau, P. Molinié, P. Léone, J. Rouxel, C. Taviot-Guého, A. Ennaqui, A. de Roy, J.P. Besse, J. Solid State Chem. 144 (1999)143-151.

${ }^{29}$ J.-M.R. Génin, C. Ruby, Solid State Sci. 10 (2008) 244-259.

${ }^{30}$ B. Rusch, J.-M.R. Génin, C. Ruby, M. Abdelmoula, P. Bonville, Solid State Sci. 10 (2008) 40-49.

${ }^{31}$ K.B. Ayala-Luis, C.B. Koch, H.C.B. Hansen, Appl. Clay Sci. 48 (2010) 334-341. 
${ }^{32}$ D.X. Gouveia, O.P. Ferreira, A.G. Souza, M.G. da Silva, J.A.C. de Paiva, O.L. Alves, J.M. Filho, J. Mater. Sci. 42 (2007) 534-538.

${ }^{33}$ A. Mendiboure, R. Schöllhorn, Chim. Miner. 23 (1987) 819-827.

${ }^{34}$ J.C. Schon, D. Alder, G. Dresselhaus, J. Phys. C 21 (1988) 5595-5614.

${ }^{35}$ A. Fogg, M. Dunn, J.S.D. O’Hare, Chem. Mater. 10 (1998) 356-360.

${ }^{36}$ M. Kaneyoshi, W. Jones, Phys. Lett. 296 (1998) 183-186.

${ }^{37}$ P.S. Braterman, Z.P. Xu, F. Yarberry, Layered double hydroxides. In: S.M. Auerbach, K.A. Carrado, P.K. Dutta (Eds), Handbook of Layered Materials, New York (2004) Taylor \& Francis, pp. 373-474.

${ }^{38}$ M. Meyn, K. Beneke, G. Lagaly, Inorg. Chem. 29 (1990) 5201-5207.

${ }^{39}$ C. Ruby, R. Aïssa, A. Géhin, J. Cortot, M. Abdelmoula, J.-M.R. Génin, C. R. Geosci. 338 (2006) 420-432.

${ }^{40}$ J.J. Bravo-Suárez, E.A. Páez-Mozo, S.T. Oyama, Quim. Nova 27 (2004) 601-614.

${ }^{41}$ M. Adachi-Pagano, C. Forano, J.P. Besse, J. Mater. Chem. 13 (2003) 1988-1993.

${ }^{42}$ M. Ogawa, H. Kaiho, Langmuir 18 (2002) 4240-4242.

${ }^{43}$ N. Morel-Desrosiers, J. Pisson, Y. Israeli, C. Taviot-Guého, J.P. Besse, J.P. Morel, J. Mater. Chem. 13 (2003) 2582-2585.

${ }^{44}$ Y. Israeli, C. Taviot-Guého, J.P. Besse, J.P. Morel, N. Morel-Desrosiers, J. Chem. Soc., Dalton Trans. (2000) 791-796.

${ }^{45}$ S. Miyata, Clays Clay Miner. 31 (1983) 305-311.

${ }^{46}$ R.P. Bontchev, S. Liu, J.L. Krumhansl, J. Voigt, T.M. Nenoff, Chem. Mater. 15 (2003) 3669-3675.

${ }^{47}$ S.P. Newman, W. Jones, New J. Chem. (1998) 105-115.

${ }^{48}$ K.K. Ravi, S.W. Marc, E.A. James, Chem. Mater. 9 (1997) 417-419.

${ }^{49}$ S. Xing, D.Q. Li, L.L. Ren, D.G. Evans, X. Duan, Huaxue Xuebao 61 (2003) 267-272.

${ }^{50}$ S. Miyata, Clays Clay Miner. 28 (1980) 50-56.

${ }^{51}$ T. Hibino, A. Tsunashima, Chem. Mater. 10 (1998) 4055-4061.

${ }^{52}$ J.S. Valente, G. Rodriguez-Gattorno, M. Valle-Orta, E. Torres-Garcia, Mater. Chem. Phys. 133 (2012) 621-629.

${ }^{53}$ C.O. Oriakhi, I.V. Farr, M.M. Lerner, Clays Clay Miner. 45 (1997) 194-202.

${ }^{54}$ H. Nakayama, N. Wada, M. Tsuhako, Int. J. Pharm. 269 (2004) 469-478.

${ }_{55}^{55}$ M. Ogawa, S. Asai, Chem Mater 12 (2000) 3253-3255.

${ }^{56}$ M.A. Aramendia, V. Borau, C Jimenez, J.M. Marinas, J.R. Ruiz, F.J. Urbano, J Solid State Chem 168 (2002) 156-161.

${ }^{57}$ Y. Zhao, F. Li, R. Zhang, D.G. Evans, X. Duan, Chem Mater 14 (2002) 4286-4291.

${ }^{58}$ H.P. Boehn, J. Steinle, C. Vieweger Angew Chem Int Ed Engl 16 (1977) 265-266.

${ }^{59}$ L. Indira, M. Dixit, P.V. Kamath, J Power Sources 52 (1994) 93-97.

${ }^{60}$ G. Hu, D. O'Hare, J. Am. Chem. Soc. 127 (2005) 17808-17813.

${ }^{61}$ V.R.L. Constantino, T. Pinnavaia, Inorg. Chem. 34 (1995) 883-892.

${ }^{62}$ R. Tessier, D. Tichit, F. Figueras, J. Kervennal, FR Patent, 9500094 (1995).

${ }^{63}$ K.K. Rao, M. Gravelle, J. Sanchez Valente, F. Figueras, J. Catal. 173 (1998) 115-121.

${ }^{64}$ S. Ueno, K. Yamaguchi, K. Yoshida, K. Ebitani, K. Kaneda, Chem. Commun. (1998) 295-296.

${ }^{65}$ E. Suzuki, M. Okamoto, Y. Ono, J. Mol. Catal. 61 (1990) 283-294.

${ }^{66}$ K. Zhu, C. Liu, X. Ye, Y. Wu, Appl. Catal. A 168 (1998) 365-372. 
${ }^{67}$ B.M. Choudary, M.L. Kantam, C.R.V. Reddy, K.K. Rao, F. Figuéras, J. Mol. Catal. A 146 (1999) 279-284.

${ }^{68}$ B.M. Choudary, M.L. Kantam, C.R.V. Reddy, S. Aranganathan, P.L. Santhi, F. Figuéras, J. Mol. Catal. A 159 (2000) 411-416.

${ }^{69}$ B.F. Sels, D.E. De Vos, P. A. Jacobs, Catal. Rev. 43 (2001) 443-488.

${ }^{70}$ E. Iglesia, D.G. Barton, J.A. Biscardi, M.J.L. Gines, S.L. Soled, Catal. Today 38 (1997) 339-360.

${ }^{71}$ D. Tichit, B. Coq, CATTECH 7 (2003) 206-217.

${ }^{72}$ Z.P. Xu, J. Zhang, M.O. Adebajo, H. Zhang, C. Zhou, Appl. Clay Sci. 53 (2011) 139-150.

${ }^{73}$ T.H. Bennur, A. Ramani, R. Bal, B.M. Chanda, S. Sivasanker, Catal. Commun. 3 (2002) $493-$ 496.

${ }^{74}$ Y.Z. Chen, C.M. Hwang, C.W. Liaw, Appl. Catal. A 169 (1998) 207-214.

${ }^{75}$ N. Das, D. Tichit, R. Durand, P. Graffin, Catal. Lett. 71 (2001) 181-185.

${ }^{76}$ B.M. Choudary, S. Madhi, N.S. Chowdari, L.M. Kantam, B. Sreedhar, J. Am. Chem. Soc. 124 (2002) 14127-14136.

${ }^{77}$ P. Levecque, H. Poelman, P. Jacobs, D. De Vos, B. Sels, Phys. Chem. Chem. Phys. 11 (2009) 2964-2975.

${ }^{78}$ S. Bhattacharjee, T.J. Dines, J.A. Anderson, J. Catal. 225 (2004) 398-407.

${ }^{79}$ B.M. Choudary, C.R.V. Reddy, B.V. Prakash, B. Bharathi, M.L. Kantam, J. Mol. Catal. A 217 (2004) 81-85.

${ }^{80}$ B.M. Choudary, B. Bharathi, C.R.V. Reddy, M.L. Kantam, K.V. Raghavan, Chem. Commun. (2001) 1736-1737.

${ }^{81}$ L. Li, Y.J. Feng, Y.S. Li, W.R. Zhao, J.L. Shi, Angew. Chem. Int. Edit. 48 (2009) 5888-5892.

${ }^{82}$ Y.S.D Yoo, A.A. Bhattacharyya, C.A. Radlowski, J.A. Karch, Appl. Catal. B 1 (1992) 169-189.

${ }^{83}$ A. Corma, A.E. Palomares, F. Rey, Appl. Catal. B 4 (1994) $29-43$.

${ }^{84}$ H.-S. Shin, M.-J. Kim, S.-Y. Nam, H.-C. Moon, Water Sci. Techn. 34 (1996) 161-168.

${ }^{85}$ A. Legrouri, M. Badreddine, A. Barroug, A. de Roy, J.-P. Besse, J. Mater. Sci. Lett. 18 (1999) 1077-1079.

${ }^{86}$ M. Lakraimi, A. Legrouri, A. Barroug, A. De Roy, J.P. Besse, J. Mater. Chem. 10 (2000) 1007-1011.

${ }^{87}$ J. Olanrewaju, B.L. Newalkar, C. Mancino, S. Komarneni, Mater. Lett. 45 (2000) 307-310.

${ }^{88}$ M. Park, C.I. Lee, Y.J. Seo, S.R. Woo, D. Shin, J. Choi, Environ. Sci. Pollut. Res. 17 (2010) 203-209.

${ }^{89}$ Y. Seida, Y. Nakano, Water Res. 34 (2000) 1487-1494.

${ }^{90}$ T. Yamamoto, T. Kodama, N. Hasegawa, M. Tsuji, Y. Tamaura, Energy Convers. Manag. 36 (1995) 637-640.

${ }^{91}$ Y. Ding, E. Alpay, Proc. Safety\& Environ. Protect. 79 (2001) 45-51.

${ }^{92}$ F. Leroux, J.-P. Besse, Chem. Mater. 13 (2001) 3507-3515.

${ }^{93}$ S. O'Leary, D. O'Hare, G. Seeley, Chem. Commun. (2002) 1506-1507.

${ }^{94}$ T. Challier, R.C.T. Slade, J. Mater. Chem. 4 (1994) 367-371.

${ }^{95}$ N.T. Whilton, P.J. Vickers, S. Mann, J. Mater. Chem. 7 (1997) 1623-1629.

${ }^{96}$ G. Camino, A. Maffezzoli, M. Braglia, M. de Lazzaro, M. Zammarano, Polymer Degrad. Stabil. 74 (2001) 457-464.

${ }^{97}$ C. Taviot-Guého, F. Leroux, Struct. Bond. 119 (2006) 121-159. 
${ }^{98}$ J. Zhu, P. Yuan, H. He, R. Frost, Q. Tao, W. Shen, T. Bostrom, J. Coll. Int. Sci. 319 (2008) 498-504.

${ }^{99}$ A. Khan, D. O'Hare, J. Mater. Chem. 12 (2002) 3191-3198.

${ }^{100}$ K. Mori, Y. Nakamura, I. Kikuchi, J. Polymer Sci.: Polymer Lett. 19 (1981) 623-628.

${ }^{101}$ A.P. Kumar, D. Depan, N. Singh Tomer, R.P. Singh, Prog. Polymer Sci. 34 (2009) 479-515.

${ }^{102}$ U. Costantino, V. Ambrogi, M. Nocchetti, L. Perioli, Mic. Mes. Mater. 107 (2008) 149-160.

${ }^{103}$ A.I. Khan, A.J. Norquist, D. O'Hare, Chem. Commun. 22 (2001) 2342-2343.

${ }^{104}$ J.H. Choy, J.Jung, S.J.M. Oh, M. Park, J. Jeong, Y.K. Kang, O.J. Han, Biomat. 25 (2004) 3059-3064.

105 J.H. Choy, E.Y. Jung, Y.H. Son, M. Park, J. Phys. Chem. Solids 65 (2004) 509-512.

${ }^{106}$ J.H. Choy, S.Y. Kwak, J.S. Park, Y. J. Jeong, J. Mater. Chem. 11 (2001) 1671-1674.

${ }^{107}$ J.H. Choy, S.Y. Kwak, J.S. Park, Y.J. Jeong, J. Portier, J. Am. Chem. Soc. 121 (1999) 1399-1400.

${ }^{108}$ J.H. Choy, Y.H. Son, Bull. Korean Chem. Soc. 25 (2004) 122-126.

${ }^{109}$ S.Y. Kwak, W.M. Kriven, M.A. Wallig, J.H. Choy, Biomater. 25 (2004) 5995-6001.

${ }^{110}$ S.H. Hwang, Y.S. Han, J.H. Choy, Bull. Korean Chem. Soc. 22 (2001) 1019-1022.

${ }^{111}$ J.H. Yang, S.Y. Lee, Y.S. Han, K.C. Park, J.H. Choy, Bull. Korean Chem. Soc. 24 (2003) 499-503.

${ }^{112}$ M.Z. bin Hussein, Z. Zainal, A.H. Yahaya, D.W.V. Foo, J. Control. Release 82 (2002) 417-427.

${ }^{113}$ P. Sipos, G. Hefter, P.M. May, The Analyst 125 (2000) 955-958.

${ }^{114}$ P. Sipos, G. Hefter, P.M. May, J. Chem. Eng. Data 45 (2000) 613-617.

115 S.-H. Yang, A.X. Gray, A.M. Kaiser, B.S. Mun, B.C. Sell, J.B. Kortright, C. S. Fadley, J. Appl. Phys. 113 (2013) 073513.

${ }^{116}$ G. Hahner, Chem. Soc. Rev. 35 (2006) 12, 1244-1255.

${ }^{117}$ M.A. Woo, T.W. Kim, M.-J. Paek, H.-W. Ha, J.-H. Choy, S.-J. Hwang, J. Solid State Chem. 184 (2011) 171-176.

${ }^{118}$ W. Meng, F. Li, D.G. Evans, X. Duan, X., Mater. Res. Bull. 39 (2004) 1185-1193.

${ }^{119}$ D. Evans, R. Slade, Struct. Bond. 119 (2006) 1-87.

${ }^{120}$ J. Zhou, Z. P. Xu, S. Qiao, Q. Liu, Y. Xu, G. Qian J. Hazard. Mater. 189 (2011) 586-594.

${ }^{121}$ F. Millange, R.I. Walton, L.X. Lei, D. O’Hare, Chem. Mater. 12 (2000) 1990-1994.

${ }^{122}$ V. Rives, S. Kannan, J Mater Chem 10 (2000) 489-495.

${ }^{123}$ H.C.B. Hansen, C.B. Koch, R.M. Taylor, J. Solid State Chem. 113 (1994) 46-53.

${ }^{124}$ G. Hu, D. O'Hare, D. J. Am. Chem. Soc. 127 (2005) 17808-17813.

${ }^{125}$ Y. Zubavichus, A. Shaporenko, M. Grunze, M. Zharnikov, J. Phys. Chem. A 109 (2005) 6998-7000.

${ }^{126}$ A. Clearfield, M. Kieke, J. Kwan, J.L. Colon, R.C. Wang, J. Inclusion Phenom. Mol. Recognit. Chem. 11 (1991) 361-378.

${ }^{127}$ Z.P. Xu, P.S. Braterman, J. Mater. Chem. 13 (2003) 268-273.

${ }^{128}$ K. Yamaguchi, K. Mori, T. Mizugaki, K. Ebitani and K. Kaneda, J. Org. Chem. 65 (2000) 6897-6903.

${ }^{129}$ F. Wypych, G.A. Bubniak, M. Halma, S. Nakagaki, J. Coll. Int. Sci. 264 (2003) 203-207.

${ }^{130}$ M. Gruttadauria, F. Giacalone, R. Noto, Chem. Soc. Rev. 37 (2008) 1666-1688.

${ }^{131}$ S.-E. Park, E.A. Prasetyanto, Top. Catal. 52 (2009) 91-100. 
${ }^{132}$ C. Aprile, F. Giacalone, M. Gruttadauria, A.M. Marculescu, R. Noto, J.D. Revell, H. Helma Wennemers, Green Chem. 9 (2007) 1328-1334.

${ }^{133}$ E.A. Prasetyanto, S.-C. Lee, S.-M. Jeong, S-E. Park, Chem. Commun. (2008) 1995-1997. ${ }^{134}$ Z. An, W. Zhang, H. Shi, J. He, J. Catal. 241 (2006) 319-327.

${ }^{135}$ B.M. Choudary, B. Kavita, N.S. Chowdari, B. Sreedhar, M.L. Kantam, Catal. Lett. 78. (2002) 373-377.

${ }^{136}$ R. Bruckner, In: Harmata M (ed) Organic reaction mechanisms. Reactions, stereo-chemistry and synthesis. Springer-Verlag, Berlin, 2010, p. 530. 


\section{MAGYAR NYELVÜ ÖSSZEFOGLALÓ (HUNGARIAN SUMMARY)}

A réteges kettős hidroxidok (LDH-k) anioncserélő tulajdonságuknak köszönhetően különleges csoportot alkotnak a réteges szerkezetủ anyagok között. A nagyszámú kationcserélő anyaggal szemben az anioncserélő ásványok ritkábban fordulnak elő. A réteges kettős hidroxidok alapképviselöje a hidrotalcit, amely $\mathrm{Mg}(\mathrm{OH})_{2}$ (brucit) alapú. Itt a $\mathrm{Mg}(\mathrm{II})$ ionok egy részét $\mathrm{Al}(\mathrm{III})$-ionok helyettesítik. A réteg szerkezete ettől nem sérül, de pozitív töltésü lesz. Ezt a rétegek között elhelyezkedő (interkalált), telejesen vagy részlegesen hidratált egyszerủ anionok kompenzálják.

Munkám során hidrotalcit- $(\mathrm{MgFe})$ és hidrokalumit- $(\mathrm{CaFe})$ típusú réteges kettős hidroxidok szintézisét optimalizáltam, az együttes lecsapás módszerét alkalmazva. Az elöállított anyagok szerkezetvizsgálatát (por)röntgendiffraktometria (XRD), Mössbauer spektroszkópia, röntgenabszorpciós spektroszkópia (XAS), termogravimetria (TG/DTG), induktív csatolású plazma optikai emissziós spektrometria (ICP-OES), infravörös spektroszkópia (FTIR), pásztázó elektronmikroszkópia (SEM), energiadiszperzív fluoreszcenciás mikroanalízis (EDX) és transzmissziós elektronmikroszkópia (TEM) segítségével végeztem el. Az elöállított LDH-k röntgendiffraktogramjai igazolták a réteges szerkezetet, és lehtővé tették a rácsparaméterek meghatározását. Az optimális szintéziskörülmények kialakításakor fontos szempont volt az, hogyha a réteges kettős hidroxidok anioncserélő tulajdonságának kihasználása a cél, a szintézist $\mathrm{N}_{2}$ atmoszféra alatt kell végrehajtani, és a pH növeléséhez használt $\mathrm{NaOH}$ koncentrációjának $3 \mathrm{M}$ alatt kell lennie. Azt találtam, hogy a $\mathrm{Ca}(\mathrm{II}): \mathrm{Fe}(\mathrm{III})$ arány növelésével a $\mathrm{Ca}(\mathrm{OH})_{2}$ mennyisége közel lineárisan nő 0 tömeg\%-ról $\sim 60$ tömeg\%.-ig. Ezzel egyidejüleg az anyagok stabilitása is növekszik - a melléktermékektől mentes hidrokalumit szerkezetú LDH (Ca(II):Fe(III) = 2) a legkevésbé stabilis. $\mathrm{Az}^{57} \mathrm{Fe}$ Mössbauer spektroszkópiás mérések szerint a Fe(III) nagyspinü, némileg torzult oktaéderes környezetben van mind a CaFe-, mind a MgFe-LDH esetén az összes kiindulási fémarány esetén.

A rétegvastagságot, ami elengedhetetlen a térbeli elrendezödés megadásához, a TEM dark-field felvételekből becsültem meg. A kapott $0.2 \mathrm{~nm}$ jó egyezést mutat az irodalomban megtalálható, nagyfelbontású XRD-ből nyert 0.178 nm-rel.

A N-tartalmú heterociklusos karboxilsavak interkalálása a dehidratációs-rehidratációs módszerrel történt, ami lényegében abból áll, hogy a kiindulási $\mathrm{Ca}_{3} \mathrm{Fe}-\mathrm{LDH}-\mathrm{t} 500{ }^{\circ} \mathrm{C}$-on, $\mathrm{N}_{2}$ atmoszférában 5 órán keresztül hőkezeljük, ezáltal a szerkezet összeomlik és egy sok hibahellyel rendelkező keverék fémoxid jön létre. Ezt ( $\mathrm{N}_{2}$ atmoszférában) enyhén lúgos, az 
aniont is tartalmazó aceton/víz ill. etanol/víz elegyben kevertetjük, ezáltal a szerkezet az LDH tulajdonságainak köszönhetően visszaáll, közben pedig az interkaláció is lejátszódik. Az így előállított szerves-szervetlen hibrid anyagok szerkezetét és morfológiáját a már felsorolt vizsgálati módszerekkel jellemeztem, kiegészítve UV-Vis spektroszkópiás mérésekkel és molekulamodellezéssel. A szintézis során használt oldószerelegy az interkaláció módját nagymértékben befolyásolta. Az interkalált anionok az oldószertől függően eltérő térbeli elrendezésben épültek be a rétegek közé. Az interkalált anionok méretét a PM3 szemiempirikus kvantumkémiai módszerrel számolt paralelepipedonok dimenziójából számoltam ki. Mindezek alapján közelítő becslés tehető az anionok térbeli elhelyezkedését illetően a rétegek között. Az etanol: $\mathrm{H}_{2} \mathrm{O}: \mathrm{NaOH}$ és az aceton: $\mathrm{H}_{2} \mathrm{O}: \mathrm{NaOH}$ oldószerelegyek lehetővé tették a N-tartalmú aromás, részlegesen vagy teljesen telített heterociklusok interkalálását vízszintes vagy függőleges elrendezésben a rétegekhez képest, megőrizve a réteges kettős hidroxid szerkezetét.

Az utóbbi időben a kémiai iparágak érdeklődése egyre nagyobb mértékben fordult a környezetbarát, heterogén katalízist alkalmazó folyamatok felé. Továbbra is különösen nagy kihívást jelent aktív szilárdfázisú Brønsted-típusú bázisos katalizátorok kifejlesztése, melyek jó szelektivitással katalizálják a C-C kötések kialakulását, például aldehidek és ketonok közötti kondenzációs reakciókban, melyeket a gyógyszeripari alapanyagok és a finomkemikáliák gyártása során használnak. A hőkezelés nélküli CaFe-LDH-k hatékony katalizátornak bizonyultak egy epoxidációs reakcióban - sokkal aktívabbak voltak, mint a kalcinált származékok. A 2-ciklohexén-1-on epoxidációja végbement hőkezelés nélküli CaFe-LDHkatalizátoron, különböző oldószerekben (formamid, n-hexán, ciklohexén, metanol, etanol, 2metil-2-propanol, aceton és 1,4-dioxan) és hőmérsékleteken. A legjobb eredményeket formamidban és $313 \mathrm{~K}$-en értem el, de a reakció jó aktivitássl ment n-hexánban, cikohexénben és metanolban is. A hőkezelés nélküli MgAl-hidrotalcit, MgFe-hidrotalcit és CaAlhidrokalumit kevésbé volt aktív, mint a CaFe-hidrokalumit, de jobb katalizátornak bizonyultak a hőkezelt származékoknál (kevert fém-oxidok) vagy egyéb fém-oxidoknál, pl. titándioxidnál.

Az L-prolint már évek óta használják, mint királis organokatalizátort szerves kémiai reakciókban $\mathrm{C}-\mathrm{C}$ kötések létrehozására. Sikeresen alkalmazták aszimmetrikus intermolekuláris aldol dimerizáció katalizátoraként sokféle keton és aldehid esetében, jó hozamokat és nagy enantioszelektivitást elérve. Sok figyelmet szenteltek a katalizátor immobilizálására, amivel egyrészt ezzel könnyítjük a reakcióelegy feldolgozását, másrészt a katalizátor visszanyeré- 
sével és újraalkalmazásával kevésbé terheljük a környezetet. Kovalens kötésen keresztül funkcionalizált szilikagél állítható elő $\mathrm{N}$ - vagy C-védett L.prolin immobilizálásával klórpropilezett szilikagél felületére. A védőcsoportok eltávolítása után csak a C-terminálison keresztül kötött L-prolin mutatott katalitikus aktivitást az aceton és 2-nitrobenzaldehid közötti aldol dimerizációs rekcióban, kiváló szelektivitással, de enantioszelektivitás nélkül, illetve a benzaldehiddel kis konverzió mellett, de elfogadható szelektivitás, enantioszelektivitás értékekkel. A kereskedelmi forgalomban kapható polisztirolon kötött L-prolinol hasonló reakciókban, változatos aldehidekkel dimereket eredményezett közepes enantioszelektivitás értékekkel. Mindezek alapján megállapítottam, hogy a kovalensen immobilizált N-tartalmú heterociklusok szekunder nitrogénjének szabadnak kell maradnia a katalitikus aktvitás biztosításához.

$\mathrm{Az}$ eddig felsorolt eredmények egyértelmüen igazolják a réteges kettős hidroxidok sokoldalúságát. Különböző szerves anionokkal funkcionalizálhatók, és a sokféle területen alkalmazhatók, többek között finomvegyipari reakciók katalizátoraként. 


\section{ACKNOWLEDGEMENT}

Firstly, let me gratefully acknowledge the immense support and help of Drs István Pálinkó and Pál Sipos. My grateful thanks go to them for both the theoretical and practical encouragement and teaching that I have received from them during the years I have spent in their unique research group.

Let me also gratefully acknowledge the efforts of Dr. Ernő Kuzmann for his valuable insights and suggestions regarding Mössbauer spectroscopy. I wish to express my sincere thanks to Dr. Gábor Peintler for his detailed review and excellent advices during the preparation of this thesis. Many thanks are due, too, to all members of the Material and Solution Structure Research Group.

I thank to all who helped me in any aspects in- and outside of the University of Szeged.

Many thanks to my family and friends for the tremendous support they gave me in the last years. Finally, I would like to acknowledge the most important person in my life - my husband. He has been a constant source of strength and inspiration. 